$$
\begin{gathered}
\text { Aus dem Fachbereich Medizin } \\
\text { der Johann Wolfgang Goethe-Universität } \\
\text { Frankfurt am Main }
\end{gathered}
$$

\author{
betreut am \\ Christiane Herzog CF-Zentrum für Kinder, Jugendliche und Erwachsene \\ Medizinische Klinik I \\ Leitung: Prof. Dr. Gernot Rohde und Prof. Dr. S. Zielen
}

\title{
Comparison of surrogate parameters of prognosis (BMI, FEV1 and need of intravenous antibiotic therapy) between CF-patients with and without P. aeruginosa in Frankfurt and Moscow from 1990 to 2015
}

\author{
Dissertation \\ zur Erlangung des Doktorgrades der Medizin \\ des Fachbereichs Medizin \\ der Johann Wolfgang Goethe-Universität \\ Frankfurt am Main \\ vorgelegt von \\ Jean-Pascal Marie Dieudonné Varescon
}

aus Offenbach a. M.

Frankfurt am Main, 2020 
Dekan:

Referent/in:

Korreferent/in:

Tag der mündlichen Prüfung: $\quad$ 05.07.2021
Prof. Dr. Stefan Zeuzem

Prof. Dr. Thomas O. F. Wagner

Prof. Dr. Stefan Zielen 
Table of contents

LIST OF ABBREVIATIONS ............................................................

LIST OF FIGURES

LIST OF TABLES

KEYWORDS …............................................................................11

1. INTRODUCTION ........................................................................12

1.1. OVERVIEW AND EPIDEMIOLOGY ............................................ 12

1.2. ETIOLOGY ….................................................................... 12

1.3. DIAGNOSIS OF CF .......................................................... 16

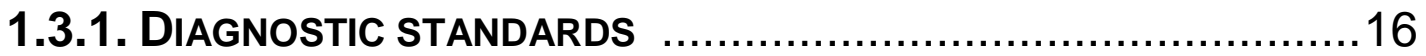

1.3.2. EXTRAPULMONARY DIAGNOSTIC ................................17

1.3.3. MONITORING ........................................................... 19

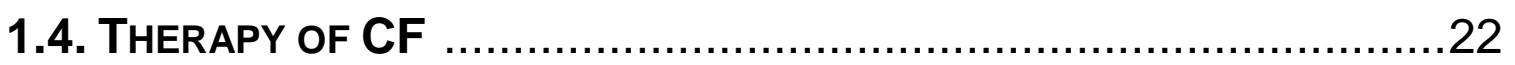

1.4.1. DRUG AND INHALATION THERAPY ..............................23

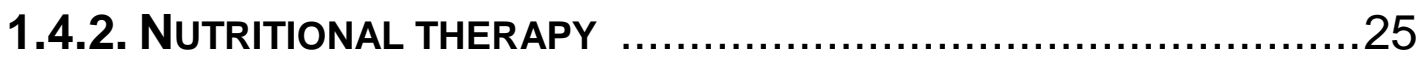

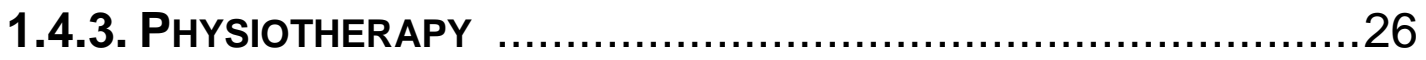

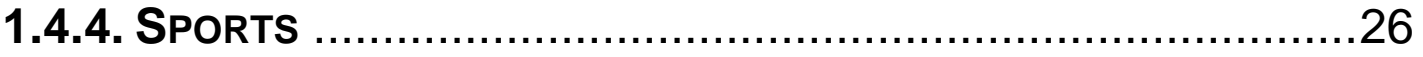

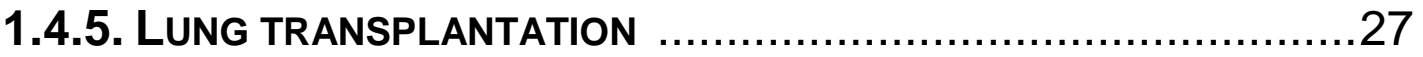

1.4.6. REHABILITATION .....................................................27

1.5. SURROGATE MARKERS OF PROGNOSIS IN CF ...........................28

1.6. OUR STUDY/ BACKGROUND .................................................29

2. MATERIAL AND METHODS.....................................................30

2.1. German PATIENT DATA ....................................................

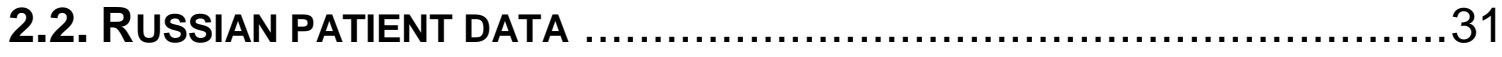


2.3. GROUPING OF DATA

2.4. DATA ANALYSIS WITH BIAS AND R-STUdIO .............................31

2.5. COMPARISON TO NORMAL POPULATION ...................................32

2.6. COMPARISON OF STANDARDS OF CARE IN BOTH CENTERS

WITH CF GUIDELINES .................................................... 32

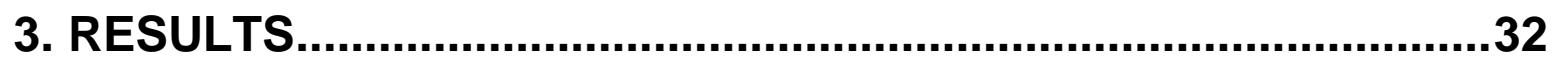

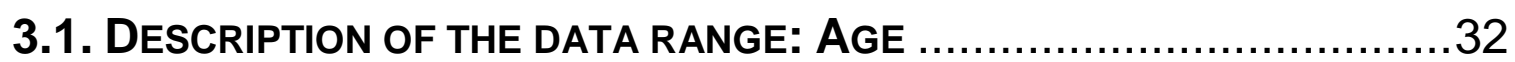

3.2. Description OF THE DATA RANGE: GENDER DISTRIBUTION,

P. AERUGINOSA PRESENCE AND MORE 34

3.3. Description OF THE DATA RANGE: BMI, FEV1 AND NECESSITY OF INTRAVENOUS ANTIBIOTIC THERAPY EVOLUTION OVER TIME .........34

3.4. CoMPARISON OF BMI IN BOTH CF POPULATIONS IN $2015 \ldots \ldots \ldots \ldots . . . .40$

3.5. COMPARISON OF FEV1 IN MATCHED SAMPLES IN $2015 \ldots \ldots \ldots \ldots \ldots . . \ldots 3$

3.6. BMI COMPARISON WITH NORMAL POPULATION .........................45

3.7. CF GUIDELINE COMParison BetWeEn Frankfurt and Moscow...46

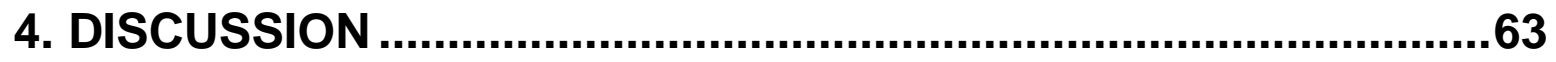

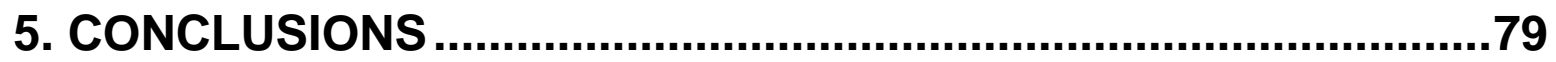

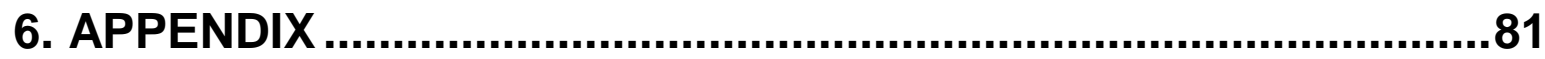

SUMMARY/ ZUSAMMENFASSUNG ............................................90

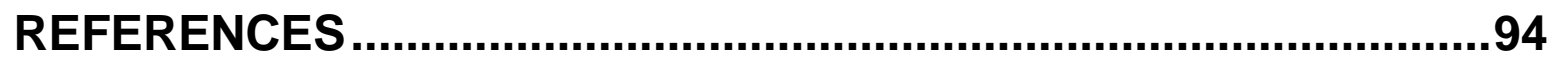

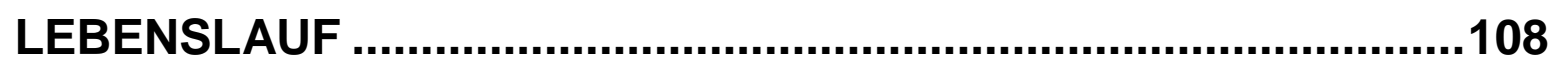

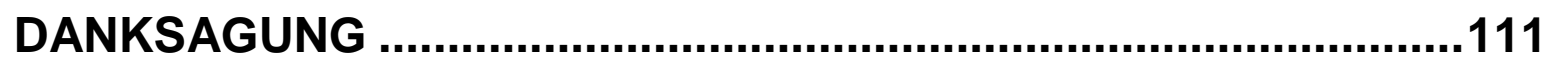

SCHRIFTLICHE ERKLÄRUNG.................................................113

ETHIKVOTUM..............................................................................114 


\section{List of abbreviations}

$\begin{array}{ll}\text { ABPA } & \text { Allergic Bronchopulmonary Aspergillosis } \\ \text { ACFLD } & \text { Advanced Cystic Fibrosis Lung Disease } \\ \text { AP } & \text { Alcalic Phosphatase } \\ \text { ATS } & \text { American Thoracic Society } \\ \text { ATS/ERS } & \text { American Thoracic Society/ European Respiratory Society } \\ \text { BMI } & \text { Body Mass Index } \\ \text { BSR } & \text { Blood Sedimentation Rate } \\ \text { Ca2+ } & \text { Calcium } \\ \text { CAMP } & \text { Cyclic Adenosine Monophosphate } \\ \text { CAUV } & \text { Congenital absence of the uterus and vagina } \\ \text { CBVAD } & \text { Congenital bilateral absence of the vas deferens } \\ \text { CF } & \text { Cystic Fibrosis } \\ \text { CFTR } & \text { Cystic Fibrosis Transmembrane Regulator } \\ \text { CHE } & \text { Cholinesterase } \\ \text { Cl- } & \text { Chloride } \\ \text { cm } & \text { Centimeters } \\ \text { CRMS } & \text { CF related metabolic syndrome } \\ \text { DEXA } & \text { Dual Energy X-Ray Absorptiometry } \\ \text { e.g. } & \text { Forempli gratia } \\ \text { etc. } & \text { et cetera } \\ \text { ECFS } & \text { European Cystic Fibrosis Society } \\ \text { ECFSPR } & \text { European Cystic Fibrosis Society Patient Registry } \\ \text { ERS } & \text { European Respiratory Society } \\ \text { F508del } & \text { Delta F508 mutation } \\ \text { FEV1 } & \text { Forced Expiratory Volume in 1 second } \\ \text { Fig. } & \text { Figure } \\ \text { FMBA } & \text { Federal Medical-Biological Agency } \\ \text { FOR } & \text { FVC }\end{array}$




$\begin{array}{ll}\text { V-GT } & \text { Gamma-glutamyltransferase } \\ \text { GLDH } & \text { Glutamate Dehydrogenase } \\ \text { HbA1c } & \text { Glycated hemoglobin, hemoglobin A1c } \\ \text { i.e. } & \text { Id est } \\ \text { i.v. } & \text { intravenous } \\ \text { IgE } & \text { Immunglobuline E } \\ \text { IgG } & \text { Immunglobuline G } \\ \text { INR } & \text { International Normalized Ratio } \\ \text { K+ } & \text { Potassium } \\ \text { kb } & \text { Kilobase } \\ \text { kg } & \text { Kilograms } \\ \text { Mg2+ } & \text { Magnesium } \\ \text { MHI } & \text { Mandatory health insurance } \\ \text { mL } & \text { Milliliter } \\ \text { mmol/L } & \text { Millimole per Liter } \\ \mathrm{n} & \text { Number } \\ \text { Na+ } & \text { Sodium } \\ \text { NaCl } & \text { Sodium Chloride } \\ \text { p } & \text { Significancy } \\ \text { P. aeruginosa / PA Pseudomonas aeruginosa } \\ \text { PSA } & \text { Prostate-specific Antigen } \\ \text { PSC } & \text { Primary Sclerosing Cholangitis } \\ \text { PTT } & \text { Partial Thromboplastin Time } \\ \text { RAST } & \text { Radioallergosorbent Test } \\ \text { SD } & \text { Standard deviation } \\ \text { SGOT } & \text { Serum Glutamic Oxaloacetic Transaminase } \\ \text { SGPT } & \text { Serum Glutamic Pyruvic Transaminase } \\ \text { TIBC } & \text { Total Iron Binding Capacity } \\ \text { TTE } & \text { Vs. }\end{array}$




\section{List of figures}

Figure 1: A normal functioning CFTR channel in a healthy person..............14

Figure 2: $\quad$ A dysfunctional CFTR channel in a patient with cystic fibrosis........15

Figure 3: $\quad$ Differences in age in both CF-populations.

A) Age distribution of CF-patients in both centers described in dot plots. 33

B) Box plot of patients' age representing median, first quartile and third quartile.

Figure 4: A) Intravenous antibiotic therapies in Frankfurt in 2015

(relative frequency).

B) Intravenous antibiotic therapies in Moscow in 2015 (relative frequency).

Figure 5: $\quad$ Box plots representing BMI comparison of patients for 2015 with median, first quartile and third quartile.
A) Patients aged 16 to 18 years. 40
B) Patients aged 19 to 22 years. 40
C) Patients aged 23 to 29 years. 41
D) Patients aged 30 to 35 years.
E) Patients older than 35 years.

Figure 6: $\quad$ A) Box plot representing FEV1 comparison of both samples for 2015 with median, first quartile and third quartile.

B) Empirical distribution function of FEV1 in both samples for 2015. 
Figure 7: The values show the FEV1\% in different age groups for Germany and the other ECFS countries. 66

Figure 8: The values show the FEV1\% in different age groups for the Russian Federation and the other ECFS countries.

Figure 9: Prevalence of chronic Pseudomonas aeruginosa infection observed in Germany and the Russian Federation (in \%).

Figure 10: Prevalence of chronic Pseudomonas aeruginosa infection observed in children in Germany and the Russian Federation (in \%).

Figure 11: Prevalence of chronic Pseudomonas aeruginosa infection observed in adults in Germany and the Russian Federation (in \%). 


\section{List of tables}

Table 1: Diagnostics that have to be done in CF Patients every 3 months..........................................................20

Table 2: $\quad$ Diagnostics that have to be done in CF Patients every year.

Table 3: $\quad$ BMI biometrical descriptive statistic from 1990 to 2015 including number of patient data sets, average BMI, median BMI, SD (standard deviation) $B M I$, maximum $B M I$, minimum $B M I, B M I$ range, $1^{\text {st }}$ quartile $B M I$ and $3^{\text {rd }}$ quartile $B M I$.

Table 4: $\quad$ Biometrical statistical analysis of FEV1 in 2015 for both samples.

Table 5: Data from the German federal office of statistics show mean BMI in Germany for different age categories in 2017

Table 6: $\quad$ Application of CF guidelines in Frankfurt and

Moscow. $.46-63$

Table 7: $\quad$ BMI: descriptive statistics, comparison by country, age and sex groups, 2017. 64

Table 8: $\quad$ FEV1\%: descriptive statistics, comparison by country and age groups, 2017. 65

Table 9: Prevalence of chronic bacterial infection in all patients seen in 2017 , by country. $.68-70$ 
Table 10: $\quad$ BMI biometrical descriptive statistics from 1990 to

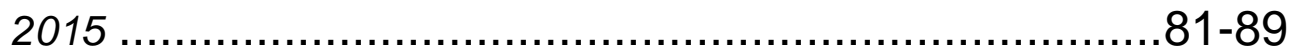




\section{Keywords:}

Cystic fibrosis, BMI, FEV1, intravenous antibiotic therapy, lung function, P. aeruginosa, surrogate parameters 


\section{Introduction}

\subsection{Overview and epidemiology}

Cystic fibrosis (CF) is a rare genetic disease characterized by a loss of function of the cystic fibrosis transmembrane conductance regulator (CFTR) in different organs ${ }^{1}$. Inheritance of $C F$ is autosomal recessive. It's a rare disease and affects about 8000 known patients ${ }^{2,3}$ in Germany in 2017. In Russia the ECFSPR (European Cystic Fibrosis Society Patient Registry) registered around 3200 patients $^{3}$ with an estimated coverage of $95 \%$, which comes down to an estimated number of 3500 patients in the whole Russian Federation. In the last years, the lifetime prognosis of CF has increased all over the world due to earlier diagnosis and improved therapy including new medications. Newborn babies with CF in Germany have been calculated to have a lifetime prognosis reaching approximately 65 years ${ }^{2}$. According to the 2017 annual ECFSPR report more than $50 \%$ of German CF patients are older than 18 years $\left(57.85 \%\right.$ in $\left.2017^{3}\right)$. In Russia, more than $75 \%$ were at childhood age $\left(76.13 \%\right.$ under 18 years old in $\left.2017^{3}\right)$. CF patients' mean age in Germany was 22.4 years in $2017^{3}$ and 12.4 years in Russia the same year ${ }^{3}$. Median age was 20.9 years in Germany while it was 9.9 years in Russia in $2017^{3}$.

\subsection{Etiology}

The physiological basis of CF is a loss of function of the CFTR which is the result of a mutation in the CFTR gene located on a $250 \mathrm{~kb}$ large region in the long arm of chromosome $7^{1,4}$. More than 2000 CFTR mutations have been reported according to John Hopkins University until June $2020^{5,6}$. Most of these are missense mutations amounting to more than 800 , representing almost $40 \%$ of all known mutations. Frameshift mutations are also very widespread (more than 330 or approximately $16 \%$ of mutations ${ }^{5}$ ). The most common mutation in the world and in Germany in 2017 was the F508del (delta F508) mutations representing approximately 48 percent homozygotic and 35 percent heterozygotic mutations ${ }^{3}$. In comparison, among the Russian patients, the amount of F508del homozygotes in the CF popu- 
lation was approximately 30 percent and F508del heterozygosity was found in 45 percent $^{3}$. Patients who carry the F508del homozygotic mutation, although representing the largest group of CF patients, show a wide variety of the clinical disease phenotypes ${ }^{7}$.

The CF gene is coding for an ABC (ATP-binding cassette) membrane protein which regulates the cAMP dependent chloride channel ${ }^{4}$. Five to si $^{8}$ different types of mutations have been described, where class I mutations induce a complete loss of function of the CFTR protein ${ }^{9}$. In contrast, class II mutations cause a synthesis defect $^{10}$, class III lead to a dysfunctional regulation ${ }^{11}$, class IV are associated with a changed conductivity ${ }^{12}$ of the channel, and class $V$ mutations cause a lower stability ${ }^{13}$ of the CFTR protein. In post endoplasmic reticulum compartments and the plasma membrane class VI mutations destabilize the channel ${ }^{8}$.

In sequel of these mutations the produced CFTR channels are partially or completely inoperative or have a loss of function. Normally, this channel is involved in the production of the airways liquid layer and thus in the equilibrium production and physicochemical characteristics of mucus. In the case of cystic fibrosis, the deteriorated channels lead to a mucus of higher viscosity in various organs (e.g. lung, vas deferens, pancreas $)^{14}$. 


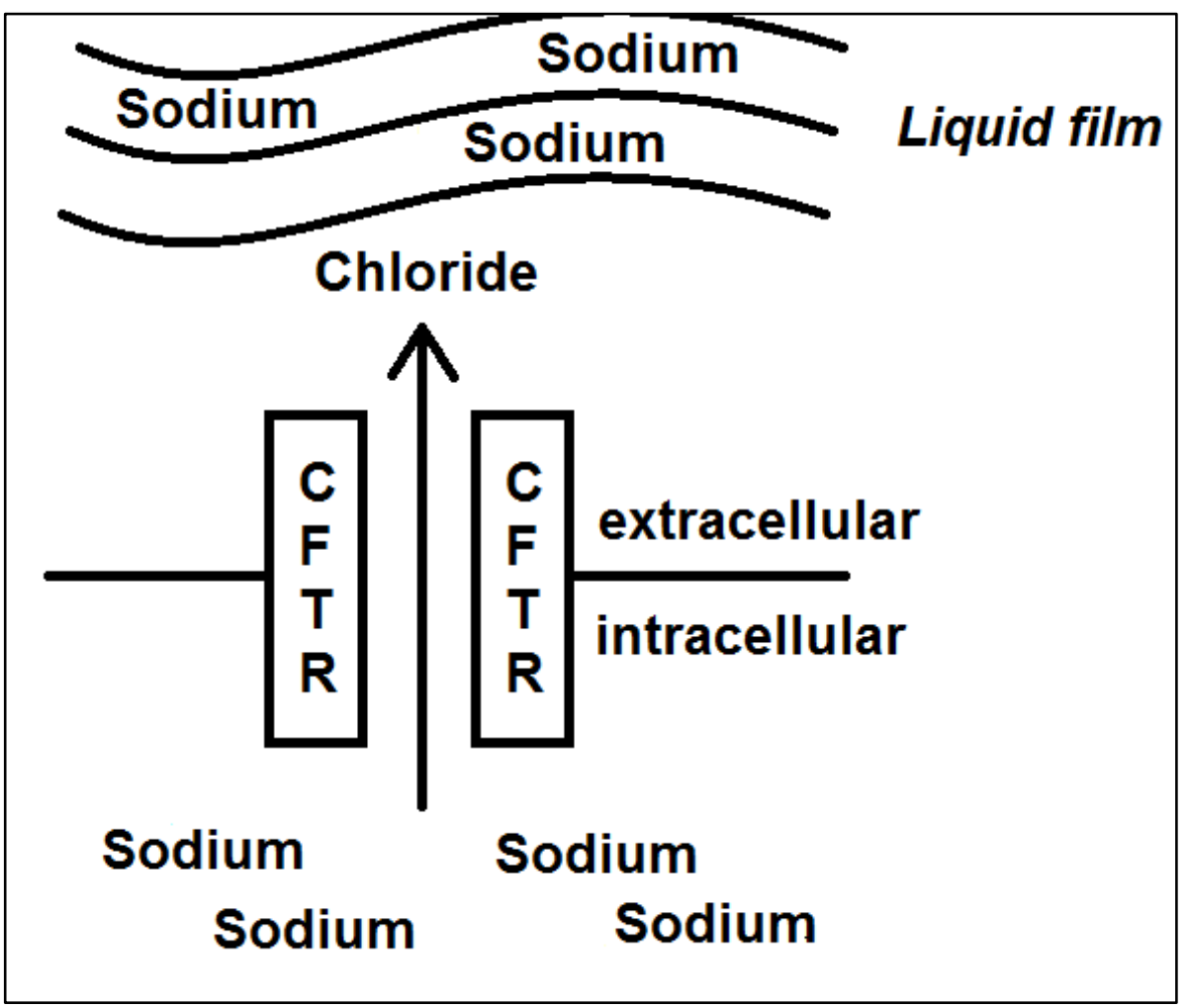

Fig. 1: A normal functioning CFTR channel in a healthy person. Chloride is transported through the channel and combines with sodium to form salt ( $\mathrm{NaCl})$. The salt mixes with water to form a thin liquid film around the cell. Graphic adapted from "Mukoviszidose - Ursache, Krankheitsbild und Therapie" by Melichar \& Hogardt. ${ }^{2}$ 


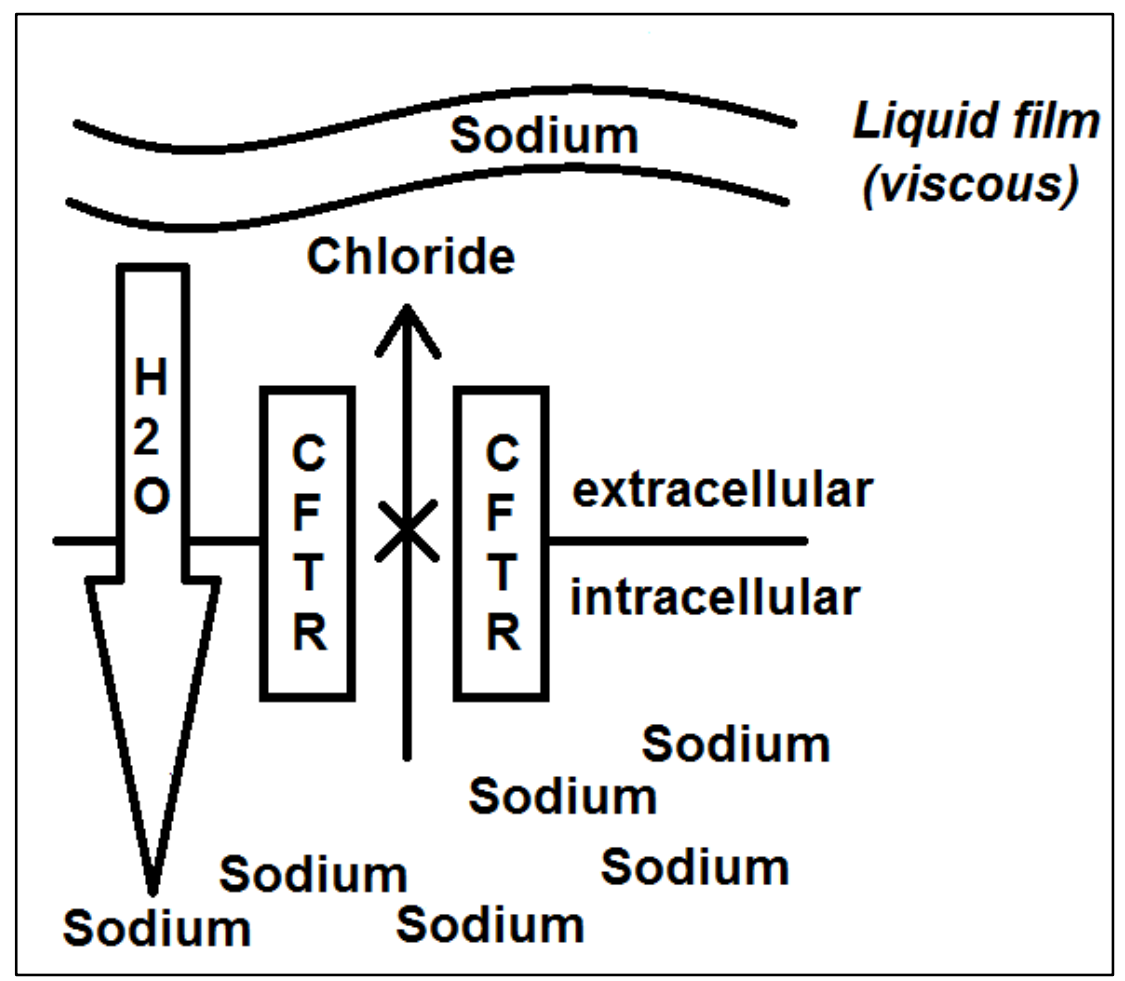

Fig. 2: A dysfunctional CFTR channel in a patient with cystic fibrosis. Small quantities or no chloride can pass through the cell membrane. Decreased salt concentrations outside the cell are the consequence and higher salt concentrations are found inside the secretory cells. The water follows the salt gradient and migrates into the cell according to the osmotic principle. In sequel, the extracellular secretions have a decreased salt and water content, solidify, and become more viscous. Graphic adapted from "Mukoviszidose - Ursache, Krankheitsbild und Therapie" by Melichar \& Hogardt $^{2}$

Patients with class I-III mutations often show relevant pancreas insufficiency. In contrast, patients with class IV-V mutations often have sufficient CFTR function and are not pancreas insufficient ${ }^{15}$. Such a relatively close genotype-phenotype correlation has not been shown for the degree of the lung disease ${ }^{7}$. Other glands affected by the disease are the secretory glands in the skin, the intestine and the salivatory glands ${ }^{16}$. Another important repercussion of CFTR mutation could be the congenital bilateral absence of the vas deferens (CBVAD) ${ }^{17}$, which results in the absence of the anatomic ducts through which spermatozoa pass from the testes to 
the urethra. It leads to obstructive azoospermia and causes infertility in men. The congenital absence of the uterus and vagina (CAUV) has also been observed in $\mathrm{CF}$ patients ${ }^{18}$. Moreover, a minor problem is the modification of the lacrimal gland ductal secretion, which can lead to dry eyes ${ }^{19-21}$. A modification of the lacrimal gland ductal secretion was already shown in the mouse model ${ }^{22}$.

\subsection{Diagnosis of CF}

\subsubsection{Diagnostic standards}

Early diagnosis of CF is important for early onset of therapy, a reduction of consequential damage, and a better prognosis. If no siblings are affected, further diagnostic steps are justified when clinical symptoms appear, including gastrointestinal symptoms (meconium ileus, fatty stools) and/or pulmonary problems ${ }^{4}$. The diagnostic tools often used are the sweat test, the CFTR mutation analysis and in vivo or ex vivo CFTR bioassays ${ }^{23}$. The last one is a physiological assay, which measures the epithelial ion fluxes at the mucosal surface by the voltage potentials created.

Sweat test: People with CF have more chloride in their sweat than healthy people. The diagnosis can be confirmed by showing a high chloride level and can be performed in children, when they produce enough sweat. The test should be done between 10 days and at the latest 4 weeks of age for babies, with a positive newborn screening or prenatal genetic test ${ }^{24,25}$. Sweat test values do not vary when a person grows older, has a cold or a brief illness. After placing an electrode containing pilocarpine and electrolyte solution, without interaction potential with the measurements of sodium and chloride at the test site, a second electrode is installed at another place. The pilocarpine will stimulate the skin and in particular the sweat glands after inducing a mild electric current, where positive tests will show a high

chloride level. A chloride concentration above $60 \mathrm{mmol} / \mathrm{L}^{23}$ confims cystic fibrosis. Between 30 and $59 \mathrm{mmol} / \mathrm{L}, \mathrm{CF}$ is possible and additional testing is needed and the sweat test is repeated. If the newborn screening is positive, the sweat test falls 
into the intermediate range, and if there is one or no CF causing mutation the result will be classified as CF related metabolic syndrome $(\mathrm{CRMS})^{25}$. For results falling into the intermediate range with unknown mutations of the patients or undefined CFTR genotype further testing is recommended ${ }^{25}$. If further tests are neither available nor possible for other reasons, the patient may be considered to have CF related disorder. A chloride concentration of $29 \mathrm{mmol} / \mathrm{L}$ or lower in the sweat test indicates CF is unlikely, regardless of age. Patients with this result, a positive newborn screening and two CFTR gene mutations or, with at least one mutation which does not cause any physical CF symptoms, are classified to have CRMS.

By genetic testing, the diagnosis can be secured when mutations are found in both copies of the CFTR gene (homozygotic or compound heterozygotic). Missing mutations of this gene, however, by itself cannot exclude CF. The common test arrays only test for the most common mutations and other mutations have to be searched for with other techniques (gene sequencing) ${ }^{4}$. Furthermore, unknown mutations may exist and have to be taken into account. In summary, if the clinical presentation of a patient suggests CF, a stepwise approach has to be followed, starting with the sweat test and sometimes going to gene testing and physiological tests on mucosal cells. Measurements of potential differences in nasal or rectal mucosa were tested and are established for complicated or borderline cases ${ }^{2326}$.

\subsubsection{Extrapulmonary diagnostic}

Extrapulmonary manifestations can also lead to CF diagnosis. Extrapulmonary symptoms can be a result of primary ${ }^{4} \mathrm{CF}$ manifestation such as exocrine pancreatic insufficiency, cholestasis, infertility or a result of secondary/late ${ }^{4}$ complications such as endocrine pancreatic insufficiency, liver cirrhosis, or osteoporosis.

A meconium ileus occurs in $20 \%$ of patients and often is the first manifestation of $\mathrm{CF}^{27}$. The thickened and adhesive meconium obstructs the intestinal lumen. The simple and the complex meconium ileus are both described as major forms ${ }^{28}$. The viscous meconium leads to the obstruction of the terminal ileum and, with the intes- 
tinal tract still intact ${ }^{27}$, the proximal parts of the small intestine become dilated with additional gas, fluid and meconium for simple meconium ileus forms ${ }^{27}$, which appear immediately at birth ${ }^{29}$. In utero genetic diagnosis of CF and ultrasound of the abdomen enable an early diagnosis, bilious vomiting and failure to stool are further indicators. Complex meconium ileus presents earlier in utero and sometimes postnatally ${ }^{29}$. Severe complications like atresia, prenatal volvulus, ischemic necrosis or perforation have been described, sometimes with pseudocyst formation and extrusion of the meconium into the peritoneum ${ }^{27}$.

There are many mucus or secretory cells in the digestive tract. In CF, the mucus or the liquid produced is too viscous. This is particularly unfavorable for the exocrine pancreatic functions. The viscous pancreatic juice clogs the fine ducts in such a way that little or no secretions get into the intestine. The pancreatic exocrine secretions are necessary to digest food into absorbable nutrients; if the food is not digested by these pancreatic secretions, it cannot be absorbed in the small intestine and all nutrients and calories get lost. Sugar, fat and protein proceed into the large intestine. There, these nutritional components are broken down by the bacteria of the intestinal flora. This causes flatulence and greasy shiny stools or diarrhea and abdominal pain. About $85 \%$ of the CF population is pancreatic insufficient before one year of $\mathrm{age}^{30}$. This is why untreated CF patients do not thrive normally. Endocrine function is affected later ${ }^{31}$, but around $20 \%$ of adolescents and later, $40-50 \%$ of adults develop CF related diabetes. This type of diabetes occurs 6 years ${ }^{32}$ after an impaired glucose utilizeation can be demonstrated ${ }^{31}$ and increases mortality in CF patients.

A dysfunction of CFTR channels lead to cholestatic liver disease. Reflux of viscous bile, which is also hyper-viscous in CF patients, can result in inflammation of the bile ducts ${ }^{33}$ and the liver with subsequent periportal fibrosis ${ }^{34}$. Liver alterations comprise different forms and levels such as steatosis or primary sclerosing cholangitis (PSC). Signs of steatosis are found in almost $60 \%$ of patients ${ }^{35,36}$ and CF liver disease including focal biliary cirrhosis and portal hypertension in just below 
$30 \%{ }^{35,36}$. Moreover, if the bile flows too slowly into the intestine, the absorption of fat from the food is inefficient and the stool turn beige-white causing steatorrhea.

CF liver disease is the third mortality cause in CF patients only surpassed by lung and transplantation complications. Fibrosis of the liver and liver cirrhosis are major findings ${ }^{34}$ in CF patients, necessitating regular monitoring of the liver function to counteract any change or deterioration in condition.

Due to the above-mentioned viscous consistency of the seminal fluid, but also because of abnormalities in the vas deferens and epididymis, fertility is reduced in approx. $90 \%$ of male CF patients ${ }^{17}$. Thanks to newer urological methods and assisted reproductive techniques ${ }^{37}$, these problems can be circumvented. In women, decreased mucus formation and the formation of clots in the fallopian tubes makes pregnancy considerably more unlikely ${ }^{18}$. Pregnancy, however, is feasible in CF patients but needs intensified monitoing and support to lower the associated risks ${ }^{38}$.

\subsubsection{Monitoring}

According to guidelines, patients should first be assessed and discussed in a multidisciplinary team ${ }^{39}$ and all aspects of CF care have to be evaluated, including assessment of competence of airway clearance and inhalation technique. Clinical assessments should be performed at least every 3 months and, in addition to this, at times of symptomatic deterioration ${ }^{40}$. At every clinical visit, airway cultures, including typical CF pathogens, have to be obtained to monitor and control airway infection as major driver of CF lung disease ${ }^{41}$. Drug interactions and therapy (for example for CFTR modulator therapy: liver function testing, assessment for childhood cataract) ${ }^{39}$ have to be monitored. Another aspect of clinical monitoring of CF is lung function testing. Usually, patients able to cooperate (over 5 years old) ${ }^{40}$ should be examined making use of spirometry or bodyplethysmography. Pre- and post-bronchodilatator test results according to ATS/ERS criteria should be availa$\mathrm{ble}^{42}$. 
A summary of diagnostics for CF patients is given in the two tables below. The guidelines are taken from "Standards of care" ${ }^{43}$ and "Klinische Pneumologie"4.

\begin{tabular}{|c|c|}
\hline Pre clinical & $\begin{array}{l}\text {-History (including vaccination status, } \\
\text { allergies, previous illnesses, family his- } \\
\text { tory, and smoking history) }\end{array}$ \\
\hline Clinical examinations & $\begin{array}{l}\text {-Physical examination including anthro- } \\
\text { pometry (height, weight, BMI calcula- } \\
\text { tion) } \\
\text {-Sputum culture } \\
\text {-Pulse Oximetry } \\
\text {-Spirometry }\end{array}$ \\
\hline Laboratory requirement & $\begin{array}{l}\text {-Differential blood } r \\
\text {-Inflammation markers (e.g. C-reactive } \\
\text { protein, BSR, lgG) }\end{array}$ \\
\hline
\end{tabular}

Table 1: Diagnostics that have to be done in CF Patients every 3 months 


\begin{tabular}{|c|c|}
\hline Clinical examinations & $\begin{array}{l}\text {-Bodyplethysmography } \\
\text {-Capillary blood gas analysis }{ }^{* *} \\
\text {-Chest X-ray (in two directions in adults) } \\
\text {-Abdominal sonography } \\
\text {-Oral glucose tolerance test (10 years of } \\
\text { age and older) } \\
\text {-Ergometry (over } 10 \text { years old: tread- } \\
\text { mill; parts with limited gas exchange: 6- } \\
\text { minute walk) } \\
\text {-Bone density measurement (female } \\
\text { over } 12 \text { years old and male over } 13 \\
\text { years of age: every } 1-2 \text { years, e.g. by } \\
\text { DEXA scan) } \\
\text {-Transthoracic Echocardiography (TTE) } \\
\text {-Nutritional advice (if necessary, } 24- \\
\text { hour stool fat determination, elastase I } \\
\text { in the stool) } \\
\text {-Checking physiotherapy (including } \\
\text { checking the nebulizer technique) } \\
\text {-Contact with psychologist / social } \\
\text { counseling }\end{array}$ \\
\hline Laboratory requirement & $\begin{array}{l}\text {-Electrolytes (Na+, K+, Cl-, Mg2+, } \\
\mathrm{Ca} 2+, \text { Phosphate) } \\
\text {-Kidney function (creatinine, urea, uric } \\
\text { acid, creatinine clearance) } \\
\text {-Liver function (SGOT, SGPT, AP, Y- } \\
\text { GT, CHE, GLDH, total bilirubine) } \\
\text { Coagulation analysis (INR, PTT, } \\
\text { thrombine time, fibrinogen) } \\
\text {-Immunoglobulins quantitatively (IgG, } \\
\text { IgE), Aspergillus antibodies, RAST + }\end{array}$ \\
\hline
\end{tabular}




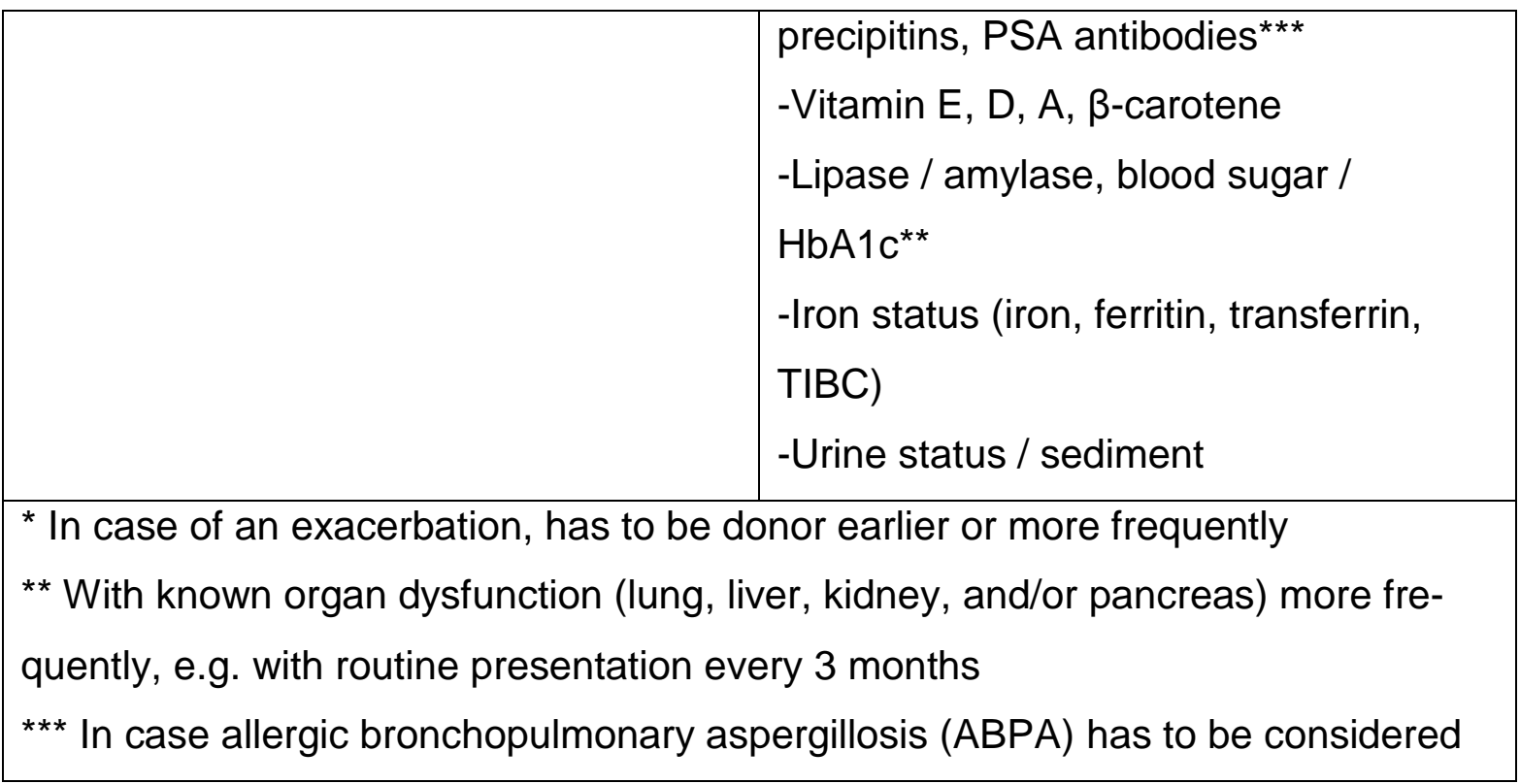

Table 2: Diagnostics that have to be done in CF Patients every year.

\subsection{Therapy of CF}

Cystic fibrosis is not contagious; however, CF patients can be infected more easily than other people with certain germs from the environment. In particular, bacteria, viruses and fungi in the airways cause larger damage in CF patients and have more chances to persist (chronic colonization). Therefore, CF patients have to take certain hygiene measures in a preventive manner. These habits include regular, thorough hand washing, because most germs are transmitted through the hands. Moreover, CF patients have to take special hygiene measures in the home environment to avoid germs that can be found in respiratory therapy equipment used ${ }^{44}$ or in wet rooms (e.g. P. aeruginosa ${ }^{45}$ to make sure they cannot enter the airways.

Different approaches exist to treat cystic fibrosis. One of the most important pillars of the comprehensive therapeutic approach is drug therapy. Other elements of therapy approaches such as dietary support ${ }^{46,47}$, physiotherapy, rehabilitation ${ }^{48}$, and sports ${ }^{48}$ should not be underestimated and can help to improve functional performance, prognosis, and quality of life of CF patients. 


\subsubsection{Drug and inhalation therapy}

Drug therapy consists of five different categories: mucolytics, anti-inflammatory drugs, medication against infection, digestive enzymes, and a new group of the CFTR modulators.

The viscous mucus in the lung has to be liquified to alleviate symptoms and sequelae. Therefore, expectorant drugs are used for inhalation therapy. The mucus becomes more fluid by adding water (for example through inhalation of sodium chloride solution ${ }^{49,50}$, also called hydrator) and the decomposition of sticky components in the slime (for example by means of the inhalation of DNase). That way, the mucus can better be removed from the lower airways and coughed up. Dornase alfa ${ }^{51}$ has a proven efficacy in CF treatment. Other options are inhalation of hypertonic saline $^{52}$ or mannitol ${ }^{53,54}$, osmotics which improve lung function by drawing water into the airways and improving airways epithelial lining fluid viscosity ${ }^{55}$.

Persistent inflammation damages the lung tissue. Inflammation can be suppressed with medications such as corticosteroids or ibuprofe $n^{56}$. If the inflammation is caused by bacterial or other infections, antibiotics and other anti-infective drugs are used.

Infections of the lungs with bacteria, viruses or fungi are treated with antibiotics, antivirals or antifungals respectively. Long time treatment with antibiotics are mostly delivered to the airways by nebulizer therapy. Alternatively, they can be given in form of tablets or in the case of pulmonary exacerbations they can be administered intravenously. Three different types of airway infections are known: an early, an intermittent and a chronic type of infection ${ }^{39}$. Inhaled antibiotic therapy is being used to reduce the amount of pulmonary bacterial load and reduce the number of exacerbations ${ }^{57}$ as part of a long-term therapy ${ }^{50}$ when different antibiotics are alternated or a single antibiotic can be used on a long term basis ${ }^{39}$. Macrolid antibiotics are often used because of their anti-inflammatory and antimicrobial effects. They are particularly effective in the treatment of chronic P. 
aeruginosa infection, when the bacteria reside in biofilms ${ }^{39,58}$. Maintenance therapy of chronic P. aeruginosa infection in CF patients is recommended with azithromy$\operatorname{cin}^{59}$. Unfortunately, the bacteria can develop resistance to the antibiotics used and may require to administer more potent or reserve antibiotics such as colistine. For the treatment of pulmonary exacerbations due to bacterial infections intravenous antibiotic treatment is indicated ${ }^{58}$. Especially patients with advanced CF lung disease (ACFLD), according to the multidisciplinary Cystic Fibrosis Foundation committee recommendation, often acquire resistant organisms ${ }^{60}$. They are frequently subject to exacerbations and in consequence need intravenous antibiotic treatment more often. This is one factor which may explain why the necessity of intravenous antibiotic treatment correlates with a decreased lifetime prognosis ${ }^{61}$.

To ensure digestion of food in the intestine, cystic fibrosis patients with pancreatic insufficiency have to take digestive enzymes with every meal. The amount of enzymes needed must be calculated to match the respective food, according to international guidelines ${ }^{62,63}$. This individualized dose calculation has to be explained to the CF patient in nutritional counseling, which should be a regular part of therapy.

The CFTR modulators and potentiators are a new type of CF drugs. They make the CFTR channel work better and can solve the problem of the viscous film produced. The precise recommendations depend on age, gating mutations and FEV $1 \%{ }^{64}$ since these drugs are extremely expensive and are working on a mutation specific principle. The advent of these therapies has been a milestone in history of cystic fibrosis therapy, but so far, the effectiveness is not wide spread enough that other therapies such as inhalation and digestive enzymes would no longer be necessary. CFTR modulators act by potentiating and correcting the protein expression of CFTR channels. Two main preparations called Lumacaftor and Ivacaftor have a demonstrated clinical efficiency. Lumacaftor is a corrector of intracellular trafficking of CFTR, helps the F508del-CFTR protein form the right shape ${ }^{65}$ and prevents premature cytosolic degradation of $\mathrm{CFTR}^{66}$. Ivacaftor is a CFTR potentiator, binds to the defective protein at the cell surface, opens the chloride channel so that chloride can flow through and increases the residual activity of de- 
fective CFTR proteins ${ }^{67}$. Both drugs have been shown to improve lung function and reduce pulmonary exacerbations significantly ${ }^{68,69}$. There are all in all four CFTR modulators ${ }^{65}$; Ivacaftor $\quad\left(\right.$ Kalydeco $\left.{ }^{\circledR}\right)$, Lumacaftor/lvacaftor $\quad\left(\right.$ Orkambi $^{\circledR}$ ), Tezacaftor/Ivacaftor $\left(\right.$ Symdeko ${ }^{\circledR}$ ), Elexacaftor/Tezacaftor/lvacaftor (Trikafta ${ }^{\mathrm{TM}}$, not approved in the European Union). Tezacaftor acts in the same way that Lumacaftor does, but has fewer side effects in combination with Ivacaftor ${ }^{65}$. Elexacaftor helps the F508del-CFTR protein form the right shape and corrects an additional flaw ${ }^{65}$ in the protein formation. The cellular transport mechanisms for ions and liquid are complex. A large number of additional other channels have been discovered and have been shown to have effects on membrane potentials, membrane interactions and CF pathology. Most of them regulate the secretion and absorption of chloride ions and have a main role in the actual aspects of today's research $^{70,71}$.

\subsubsection{Nutritional therapy}

CF patients need an effective and adequate nutritional therapy based on the mismatch between increased resting calorie needs and low energy absorption due to malabsorption. The maldigestion that occurs in most cystic fibrosis patients can be solved by taking digestive enzymes. Moreover, a balanced and high-energy diet for CF patients is particularly important. The lung obstruction goes hand in hand with an increased energy amount required for breathing and coughing. Infections, fever and diarrhea also consume a lot of energy, the demands of which are significantly higher than for healthy persons. The water and sodium chloride losses have also to be balanced and necessitate an increased contribution of fluids and salt. CF prognosis is strongly associated with the nutritional status and the $\mathrm{BMI}^{72}$. BMI but also vitamins, as well as trace elements should be monitored. A BMI in excess 20 $\mathrm{kg} / \mathrm{m}^{2}$ is recommended, ideally of $22 \mathrm{~kg} / \mathrm{m}^{2}$ for women with CF and $23 \mathrm{~kg} / \mathrm{m}^{2}$ for men with $\mathrm{CF}^{73}$. 


\subsubsection{Physiotherapy}

Regular physiotherapy is a cornerstone of cystic fibrosis therapy. Here, cystic fibrosis patients learn to use the cough productively and cough up tough mucus and stretch her chest. The breathing and stretching exercises must be done daily and start in infancy. The goals are the mobilization and elimination of the retained secretion, a relief of the auxiliary respiratory muscles and the preservation of chest mobility. Different passive (e.g. muscle stretching, skin- and connective tissue techniques, manual vibration) and active (e.g. self drainage, oscillation techniques) therapy procedures exist. They are in particular effective in combination with mucolytic and bronchodilator inhalation therapy ${ }^{74}$.

\subsubsection{Sports}

Physical activity and sports have a positive impact on the health of CF patients. They help to improve lung function, combat breathlesness ${ }^{75}$, and the flexibility of the chest. In addition, physical exercise has a positive effect on bone strength, the coordinative skills, posture and physical performance ${ }^{76}$. CF affected people can improve their performance through targeted training. Not every sport is equally suitable for CF patients. A combination of physiotherapy and fitness training shows a high degree of evidence for a better outcome and benefits for CF patients ${ }^{77-79}$. Different sports such as bungee, rugby, parachute jumping, skiing and scuba diving however are not recommended for CF patients ${ }^{80}$. During sports activities, the patients have to rehydrate themselves regularly and to replenish the body with salt and water, in particular for endurance sport due to excessive salt and water losses by sweating. Furthermore, exhaustive sports activities during infective exacerbations are highly disadvised ${ }^{80}$. 


\subsubsection{Lung transplantation}

Lung transplantation may be an opportunity for CF patients to be able to continue living if the lung is so severely damaged that it will no longer fulfill the tasks of sufficient oxygen uptake and carbon dioxide release. In CF, most patients will receive bilateral transplantation. The donor lung not having cystic fibrosis gene mutations can function normally in the body of the CF patient. Cystic fibrosis will not reappear in the transplant because of the normal genetics of the tissue. Nevertheless, a transplantation involves many risks and the mean duration of sufficient function of the transplanted organ is in the range of 10 years. It is hard to predict on an individual basis which patient will have an improved overall survival after transplantation, quality of life, though, is significantly improved in the majority of cases ${ }^{81}$. After a bilateral transplantation, the mean 3-month survival is close to $90 \%$ - even higher in large capacity transplant centers -, the 1-year survival $81 \%$ and the average long-term survival is limited to a median of 5.6 years, depending on the careful selection of recipients and the size and the experience of the transplant center ${ }^{82}$. Major complications are chronic allograft dysfunction syndrome, i.e. bronchiolitis obliterans syndrome, infections, immunosuppression induced malignancy, and lymphoproliferative diseases ${ }^{82,83}$.

\subsubsection{Rehabilitation}

Inpatient rehabilitation in qualified facilities plays an essential role in the treatment of CF patients, rehabilitation goals being stabilization of the patient condition and, if possible, also to improve health and quality of life (i.e. reaching medical goals such as improving body weight and resilience as well as the reduction of the consequences of infections of the lungs and respiratory tract). The next essential step, where rehabilitation has an important role is the restoring of participation in social and professional life. Many CF patients know the advantages and profit from the benefits of inpatient medical rehabilitation in specialized clinics ${ }^{84,85}$. Intensive therapy under the supervision of a multi-professional team ${ }^{86}$, the chance to find courage by meeting other CF patients and get new suggestions is of great value. Re- 
duction of cough and/or shortness of breath, improved physical activity with gain in physical fitness, better sleep, and general health perception as well as better integration of therapy into daily routine, enjoying leisure activities again, and being free from anxieties was noted after inpatient rehabilitation ${ }^{84}$.

There are various offerings for adults, for adolescents, and children (with and without accompanying person) or for the whole family. In this case it's called "family-oriented rehabilitation" measure (FOR) ${ }^{87}$. This type of therapy is especially utilized for diseases of the chronically ill patient, not just for CF patients ${ }^{88}$. Exchange with the CF outpatient clinic in advance of the rehabilitation is highly recommended and helps to set individual rehabilitation goals (e.g. increasing physical resilience, improving secretion mobilization).

\subsection{Surrogate markers of prognosis in CF}

Previous work has shown that prognosis in CF is related to Body-Mass-Index $(\mathrm{BMI})^{89}$, Forced Expiratory Volume in 1 second $(\mathrm{FEV} 1)^{90}$, and need of intravenous antibiotic therapy ${ }^{43}$. This is why these three parameters are recommended to be measured and monitored regularly. They have significant impact on survival and on the quality of life of CF patients ${ }^{91}$. Disease progression in cystic fibrosis (CF) is marked by deterioration of a number of physiological indicators ${ }^{91}$, especially lung function is affected ${ }^{43}$ progressively leading to pulmonary damage and in a final state, to respiratory failure. This is the consequence of a impaired mucociliary clearance. The cilia of ciliated airways cells together with airways geometry are normally responsible for transport of mucus located in the deeper airways towards the mouth, but in CF they cannot efficiently clear the airways because of the high viscosity of the mucus and additional inflammatory damage. This malfunction of the mucociliary clearance of the airways cannot be compensated by coughing and it leads to mucostasis ${ }^{92}$ and consequently to inflammation and a higher rate of infections, bronchial wall destruction i.e. bronchiectasis, emphysema and loss in pulmonary function (FEV1, FVC, hyperinflation, increased airways resistance, hypox- 
emia, and pulmonary hypertension). Moreover, in the upper airways, sinusitis and polyposis nasi can cause additional problems.

The cardiovascular system in CF shows signs of chronic overload i.e. pulmonary hypertension, cor pulmonale, right heart failure, and portal hypertension is a common problem. Gastrointestinal manifestations of CF are frequent. Liver cirrhosis is common (fatty liver, periportal fibrosis, biliary cirrhosis, cholecystolithiasis, cholangiolithiasis), the pancreatic dysfunction causes maldigestion, recurrent pancreatitis, islet cell insufficiency and CF-related diabetes). The intestine plays an important role in the overall health situation of CF patients with meconium ileus being the most prominent and early manifestation and malnutrition and vitamin deficiency being very common, while rectal prolapse and ileum invagination is rather rare. Also urogenital problems can occur. In some patients with nephrolithiasis or amyloidosis with impaired kidney function, infertility is a commonly found problem amongst males. Bone, muscle and joint problems are also possible CF manifestations with osteopenia, skeletal deformity, arthritis, atrophic skeletal muscles and hypertrophic auxiliary breathing muscles.

\subsection{Our Study/ Background}

In July 2018 the two centers of the Pulmonology Scientific Research Institute, Moscow and the University Hospital Frankfurt (Christiane Herzog CF-Zentrum) started a collaboration. Both centers care for CF-patients, children as well as adults.

A retrospective descriptive study was started after approvement (pages 114-115) by the ethics committee to look for differences between patients treated in the Moscow CF center and the Frankfurt CF center from 1990 to 2015. The question was whether there was a significant and relevant difference and if so, would this be visible in a difference of three indicators $\left(\mathrm{BM}^{89}, \mathrm{FEV} 1^{90}\right.$ and the necessity of intravenous antibiotic therapy caused by exacerbations in $\mathrm{CF}^{61}$ ) serving as surrogate markers of prognosis. BMI can be compared in stratified age classes. Higher BMI 
is related to better lung function test results (which improves consequently quality of life and survival) and in particular for underweight individuals a poorer prognosis has been reported ${ }^{89}$. FEV1 is the second parameter used to mark progression of CF lung disease and to evaluate therapeutic efficacy ${ }^{90}$. Furthermore, FEV1 can be used as prognostic tool for mortality ${ }^{90,93-95}$. Need of intravenous antibiotic therapy as a result of a severe pulmonal exacerbation ${ }^{61}$ or $P$. aeruginosa infection ${ }^{96}$ has been used as a third marker for the prognosis in $\mathrm{CF}^{61,96}$. Exacerbations have a high impact in terms of current morbidity as well as implications for long term morbidity and mortality ${ }^{61,94}$. Presence of $P$. aeruginosa is associated with higher rates of lung function decline in all age groups ${ }^{96}$. Utilization of intravenous antibiotic therapy can be used to identify cases where an infectious exacerbation has been clinically diagnosed, and thus can be used as a surrogate marker for infection.

No comparable study between German and Russian CF patients has been published so far, i.e. we are not aware of any comparative study in CF patients in this setting in the past.

\section{Materials and methods}

\subsection{German patient data}

German patient data were collected from the German national CF registry "muko.web" 97 after approvement by the ethics committee. This registry was started 1995 under the name "Qualitätssicherung Mukoviszidose" and has later been renamed into "muko.web". In the year 2015, ninety German CF centers took part in data gathering via Muko.web, describing 5331 patients in much detail (median age 20; $56.5 \%$ adults; $51.8 \%$ men; 80 died in 2015; median dying age 32$)^{97}$. Data collected from muko.web for the study were height, weight, BMI, FEV1, Forced Vital Capacity (FVC), year of birth, year of death, gender and P. aeruginosa presence. In addition to these, date of diagnosis of $\mathrm{P}$. aeruginosa infection of CF-patients in Frankfurt from 1990 to 2015 were retrieved. These data were anonymized and gathered into an Excel table. Missing values - in particular those describing the 
utilization of intravenous antibiotic therapy (not listed in muko.web) - were completed with data from the Hospital Medical record Information System (Orbis, Agfa) of the Frankfurt University Hospital. German patients were coded with the letter "f" and were assigned to group 01 . They received a three-digit numerical code "XXX".

\subsection{Russian patient data}

Russian patient data were collected directly from the medical files of the Pulmonology Scientific Research Institute, Moscow of the FMBA (Federal Medical-Biological Agency) of Russian Federation. Collected data were anonymized and regrouped in the same standardized table as in Frankfurt. Russian patients were coded with the letter " $m$ " and were assigned to group 02. In the same way as in Frankfurt they received a three-digit numerical code "XXX".

\subsection{Grouping of data}

With this anonymized code data of both centers were aggregated in one data table. Gender information was coded with 01 for male patients and 02 for female patients. Body weight was expressed in $\mathrm{kg}$ (kilograms), body height in $\mathrm{cm}$ (centimeters), FEV1 in $\mathrm{mL}$ (milliliters), $\mathrm{FVC}$ in $\mathrm{mL}$ (milliliters). The presence of $\mathrm{P}$. aeruginosa was coded with 01 , the absence of $P$. aeruginosa with 02 . Necessity of intravenous antibiotic treatment received the code 01 (02 coded no need of intravenous antibiotic treatment).

\subsection{Data analysis with Bias and R-Studio}

The complete data were biometrically analyzed with the program "Bias"98. After a descriptive approach of complete data, differences in BMI and FEV1 values were observed. Exemplarily, BMI in the two centers was compared for 2015 after separating the sample in age classes ${ }^{99,100}$. FEV1 is an inconstant value, as it depends on age, height, and gender ${ }^{101,102}$. To compare FEV1 between both centers in 2015, a script was written in Rcode and executed with R-Studio - a statistical programming tool, which can execute Rcode and analyze statistical data -. Matchlt ${ }^{102}$ was 
used to create two new comparable samples. Data pairs were matched according to the parameters influencing FEV1 (height, age, gender) ${ }^{101,103}$. The size of both samples was 100 patients and both samples were statistically not significantly different concerning height, age and gender (before matching $p<0,001$, after matching $p=0,484)$. Both matched samples were compared for their FEV1 values in a new statistical biometrical analysis with "Bias"98.

\subsection{Comparison to normal population}

Data of the study were compared to normal population data in Germany ${ }^{104}$ and the Russian Federation ${ }^{105-107}$ taking into account differences in age distribution, which are known influence CF-patient data. Especially societal differences in the normative expectations of $\mathrm{BMI}$ and actual BMI in the normal population of both countries may have an influence on samples taken in the resp. CF populations.

\subsection{Comparison of standards of care in both centers with CF guidelines}

To evaluate potential differences found, we decided to compare the standards of care for CF patients in Frankfurt and in Moscow. Therefore we took the Kerem ${ }^{43}$ CF standards of care as comparison scale. The standards of care were raised according to internal instructions and interviews with local experts.

\section{Results}

\subsection{Description of the data range: Age}

The study totalized 428 (72.91\%) patients from Moscow and 159 (27.09\%) patients from Frankfurt, which summed up to a total of 587 analyzed patients. All of them were born in 1999 or earlier. The oldest patient of this study was born in 1949. 


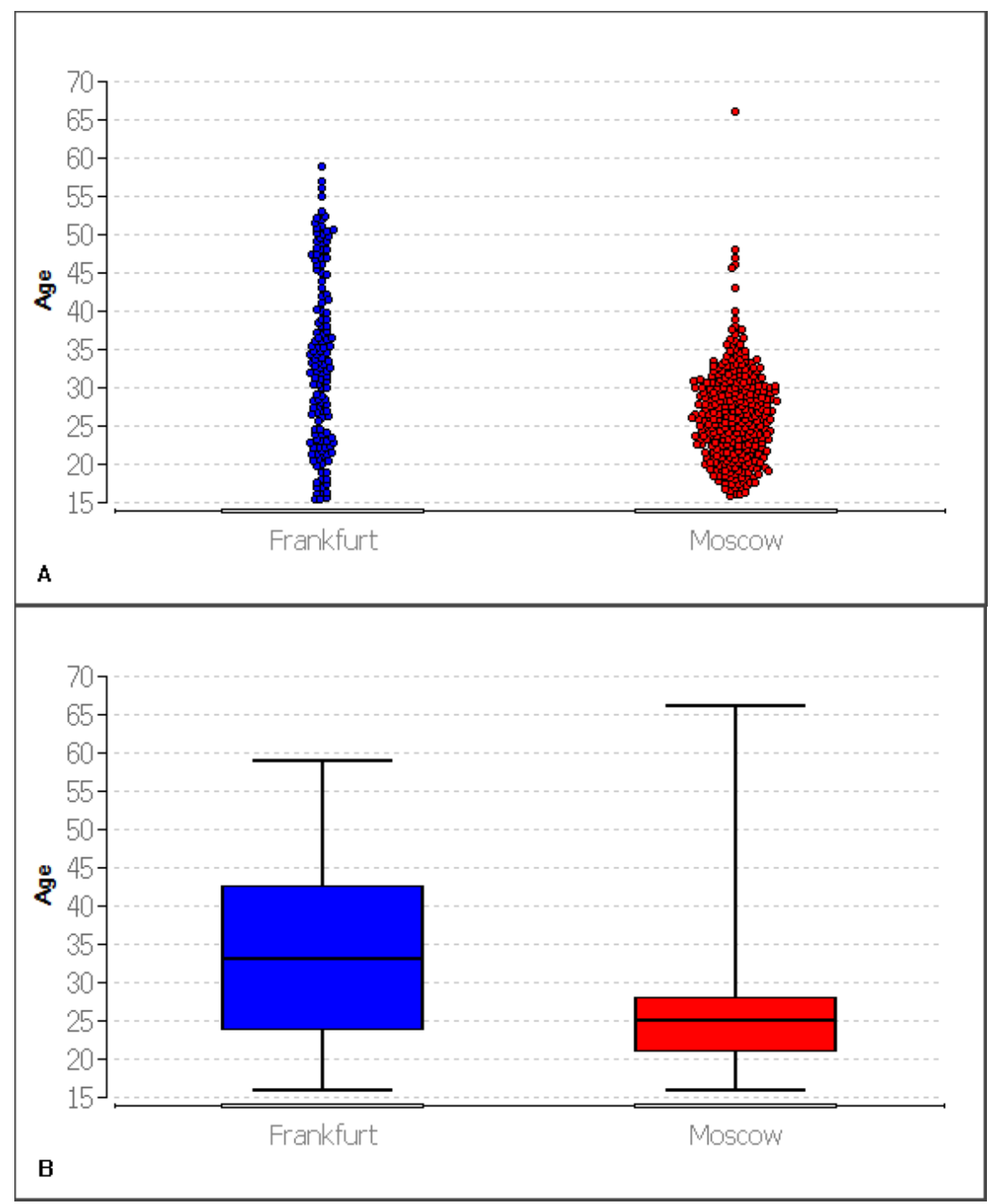

Fig. 3: Differences in age in both CF-populations.

A) Age distribution of CF-patients in both centers described in dot plots.

B) Box plot of patients' age representing median, first quartile and third quartile.

Average $^{108}$ age was 33.57 for Frankfurt, 25.59 for Moscow and for the total cohort 28.14. Standard deviation ${ }^{108}$ was 11.27 for Frankfurt, 6.10 for Moscow and 8.92 for total cohort. Median ${ }^{108}$ age was 33 for Frankfurt ( $1^{\text {st }}$ quartile 24 years, $3^{\text {rd }}$ quartile 42 years), 25 for Moscow ( $1^{\text {st }}$ quartile 21 years, $3^{\text {rd }}$ quartile 28 years) and 26 for total cohort ( $1^{\text {st }}$ quartile 22 years, $3^{\text {rd }}$ quartile 32 years). In both centers minimum age was 16 (so same for total cohort). Maximum age in Frankfurt was 59 years. In 
Moscow it was 66 years (consequently 66 years for total cohort). Finally range was 43 years for Frankfurt and 50 years for Moscow and total cohort. We can observe the Russian cohort is significantly younger than the German cohort.

\subsection{Description of the data range: Gender distribution, $P$. aeruginosa presence and more}

In Moscow 217 (50.70\%) male patients and 211 (49.30\%) female patients were counted, while in Frankfurt 92 (57.86\%) male patients and 67 (42.14\%) female patients were registered. A performed Chi-square test with Yates's correction for continuity ${ }^{108}$ confirms both samples are comparable $(p=0,147)$ for gender distribution.

348 (81.31\%) Moscow patients were infected with P. aeruginosa and 80 (18.69\%) were negative. In Frankfurt the number of $P$. aeruginosa infected patients was 137 (86.16\%) while 22 CF patients were not infected (13.84\%). In the same way as for

gender distribution a Chi-square test with Yates's correction for continuity ${ }^{108}$ was performed $(p=0.209)$. Subsequently both CF-patient populations were comparable for $P$. aeruginosa positivity $(p=0.209)$.

Six (3.77\%) patient deaths were recorded in Frankfurt ( 0 until 2015) and 114 (26.64\%) recorded patients died in Moscow (68 (15.89\%) until 2015).

\subsection{Description of the data range: BMI, FEV1 and necessity of in- travenous antibiotic therapy evolution over time}

Data were statistically analyzed and important values were calculated and entered into Table 1. Key values of BMI, FEV1 and necessity of intravenous antibiotic therapy were examined. 


\begin{tabular}{|lllllll|}
\hline Examination & Number of Patients & \multicolumn{4}{l}{ Average BMI } & \multicolumn{2}{l}{ Median BMI } \\
Year & Frankfurt & Moscow & Frankfurt & Moscow & Frankfurt & Moscow \\
\hline 1990 & 2 & 0 & 21.52 & - & 21.52 & - \\
1991 & 2 & 1 & 21.54 & 14.49 & 21.54 & 14.49 \\
1992 & 1 & 2 & 21.50 & 16.27 & 21.50 & 16.27 \\
1993 & 2 & 7 & 20.91 & 16.44 & 20.91 & 15.08 \\
1994 & 1 & 11 & 20.02 & 17.34 & 20.02 & 17.16 \\
1995 & 10 & 7 & 16.66 & 17.36 & 16.11 & 17.16 \\
1996 & 30 & 10 & 18.84 & 16.91 & 18.52 & 17.39 \\
1997 & 35 & 23 & 19.41 & 17.61 & 19.55 & 17.72 \\
1998 & 46 & 38 & 19.89 & 16.34 & 19.66 & 16.45 \\
1999 & 45 & 39 & 19.97 & 17.33 & 19.13 & 17.65 \\
2000 & 30 & 45 & 20.29 & 16.98 & 19.09 & 16.53 \\
2001 & 14 & 53 & 19.07 & 16.79 & 18.05 & 16.85 \\
2002 & 16 & 64 & 18.78 & 17.41 & 18.02 & 17.54 \\
2003 & 68 & 78 & 21.43 & 17.42 & 20.85 & 17.55 \\
2004 & 75 & 103 & 21.48 & 17.49 & 20.76 & 17.57 \\
2005 & 13 & 101 & 20.57 & 18.04 & 20.68 & 18.03 \\
2006 & 13 & 124 & 20.95 & 18.02 & 21.27 & 17.96 \\
2007 & 13 & 160 & 20.51 & 18.11 & 21.10 & 18.13 \\
2008 & 91 & 179 & 21.69 & 18.38 & 21.01 & 18.55 \\
2009 & 84 & 188 & 22.39 & 18.55 & 21.81 & 18.52 \\
2010 & 132 & 192 & 21.20 & 18.76 & 20.70 & 18.69 \\
2011 & 137 & 199 & 21.40 & 18.71 & 21.14 & 18.47 \\
2012 & 131 & 250 & 21.80 & 18.79 & 21.62 & 18.51 \\
2013 & 130 & 263 & 21.99 & 18.68 & 21.66 & 18.29 \\
2014 & 133 & 278 & 22.12 & 18.78 & 21.73 & 18.52 \\
2015 & 141 & 301 & 22.24 & 18.74 & 21.63 & 18.59 \\
\hline
\end{tabular}




\begin{tabular}{|c|c|c|c|c|c|c|}
\hline \multirow[t]{2}{*}{ Year } & \multicolumn{6}{|c|}{ BMI standard } \\
\hline & Frankfurt & Moscow & Frankfurt & Moscow & Frankfurt & Moscow \\
\hline 1990 & 0.64 & - & 21.98 & - & 21.07 & - \\
\hline 1991 & 1.13 & - & 22.34 & 14.49 & 20.75 & 14.49 \\
\hline 1992 & - & 1.75 & 21.50 & 17.51 & 21.50 & 15.03 \\
\hline 1993 & 1.26 & 2.88 & 21.80 & 20.93 & 20.02 & 13.22 \\
\hline 1994 & - & 3.82 & 20.02 & 25.00 & 20.02 & 13.34 \\
\hline 1995 & 2.29 & 2.37 & 20.64 & 22.21 & 13.68 & 15.43 \\
\hline 1996 & 3.17 & 2.21 & 25.83 & 19.37 & 14.07 & 13.47 \\
\hline 1997 & 3.18 & 2.49 & 28.22 & 22.77 & 13.71 & 13.34 \\
\hline 1998 & 3.18 & 3.58 & 27.64 & 22.77 & 13.65 & 1.92 \\
\hline 1999 & 3.52 & 2.51 & 31.11 & 22.94 & 14.88 & 12.63 \\
\hline 2000 & 4.89 & 2.71 & 37.56 & 24.15 & 13.13 & 12.70 \\
\hline 2001 & 4.02 & 2.69 & 27.76 & 22.76 & 14.60 & 12.40 \\
\hline 2002 & 2.94 & 2.65 & 24.01 & 23.23 & 14.74 & 11.65 \\
\hline 2003 & 3.76 & 2.70 & 33.30 & 23.61 & 13.98 & 11.65 \\
\hline 2004 & 4.05 & 2.77 & 35.50 & 24.88 & 12.93 & 10.82 \\
\hline 2005 & 3.22 & 2.76 & 26.35 & 25.86 & 13.73 & 12.02 \\
\hline 2006 & 3.35 & 2.83 & 26.67 & 25.72 & 14.38 & 12.03 \\
\hline 2007 & 3.58 & 2.73 & 24.97 & 25.62 & 13.89 & 12.73 \\
\hline 2008 & 4.10 & 2.79 & 40.75 & 26.23 & 14.38 & 11.83 \\
\hline 2009 & 4.41 & 2.78 & 44.29 & 26.03 & 15.34 & 12.80 \\
\hline 2010 & 4.20 & 2.84 & 45.35 & 30.03 & 14.27 & 12.60 \\
\hline 2011 & 4.18 & 2.90 & 45.52 & 31.99 & 14.35 & 12.47 \\
\hline 2012 & 4.03 & 2.69 & 45.34 & 27.73 & 13.86 & 12.47 \\
\hline 2013 & 4.04 & 2.80 & 44.47 & 27.73 & 13.86 & 10.85 \\
\hline 2014 & 4.17 & 2.86 & 45.41 & 31.46 & 14.10 & 13.02 \\
\hline 2015 & 4.13 & 2.78 & 46.60 & 31.46 & 14.17 & 11.33 \\
\hline
\end{tabular}




\begin{tabular}{|c|c|c|c|c|c|c|}
\hline \multirow[t]{2}{*}{ Year } & \multicolumn{2}{|c|}{ BMI range } & \multicolumn{2}{|c|}{ BMI 1st quartile } & \multicolumn{2}{|c|}{ BMI 3rd quartile } \\
\hline & Frankfurt & Moscow & Frankfurt & Moscow & Frankfurt & Moscow \\
\hline 1990 & 0.91 & - & - & - & - & - \\
\hline 1991 & 1.59 & 0.00 & - & - & - & - \\
\hline 1992 & 0.00 & 2.48 & - & - & - & - \\
\hline 1993 & 1.78 & 7.71 & - & 14.49 & - & 18.42 \\
\hline 1994 & 0.00 & 11.66 & - & 14.22 & - & 19.30 \\
\hline 1995 & 6.96 & 6.78 & 15.21 & 15.64 & 17.29 & 17.70 \\
\hline 1996 & 11.76 & 5.90 & 16.51 & 15.35 & 20.88 & 18.85 \\
\hline 1997 & 14.51 & 9.43 & 17.38 & 15.89 & 20.87 & 19.12 \\
\hline 1998 & 13.99 & 20.85 & 17.93 & 14.22 & 21.60 & 18.46 \\
\hline 1999 & 16.23 & 10.32 & 17.79 & 15.41 & 21.72 & 19.00 \\
\hline 2000 & 24.43 & 11.45 & 17.59 & 14.81 & 21.15 & 19.23 \\
\hline 2001 & 13.16 & 10.36 & 15.90 & 14.66 & 21.14 & 18.67 \\
\hline 2002 & 9.27 & 11.58 & 16.76 & 15.23 & 21.38 & 18.93 \\
\hline 2003 & 19.33 & 11.96 & 19.03 & 15.23 & 22.92 & 19.11 \\
\hline 2004 & 22.57 & 14.06 & 19.23 & 15.21 & 23.00 & 19.47 \\
\hline 2005 & 12.61 & 13.85 & 19.33 & 16.37 & 22.01 & 19.68 \\
\hline 2006 & 12.29 & 13.69 & 19.76 & 15.66 & 22.60 & 19.82 \\
\hline 2007 & 11.08 & 12.89 & 20.48 & 16.28 & 22.92 & 19.91 \\
\hline 2008 & 26.37 & 14.40 & 19.58 & 16.47 & 22.80 & 20.09 \\
\hline 2009 & 28.95 & 13.22 & 20.03 & 16.71 & 23.46 & 19.93 \\
\hline 2010 & 31.08 & 17.43 & 18.81 & 16.97 & 22.95 & 20.20 \\
\hline 2011 & 31.17 & 19.53 & 19.05 & 16.93 & 23.13 & 20.45 \\
\hline 2012 & 31.48 & 15.27 & 19.34 & 16.86 & 23.29 & 20.45 \\
\hline 2013 & 30.61 & 16.88 & 19.58 & 16.82 & 23.69 & 20.43 \\
\hline 2014 & 31.32 & 18.44 & 19.31 & 16.86 & 23.81 & 20.50 \\
\hline 2015 & 32.43 & 20.13 & 19.31 & 16.82 & 24.14 & 20.32 \\
\hline
\end{tabular}

Table 3: BMI biometrical descriptive statistics from 1990 to 2015 including number of patient data sets, average BMI, median BMI, SD (standard 
deviation) $B M I$, maximum $B M I$, minimum $B M I, B M I$ range, $1^{\text {st }}$ quartile $B M I$ and $3^{\text {rd }}$ quartile BMI.

Data were statistically analyzed and values were calculated and entered into Table 1. Key values of BMI, FEV1 and necessity of intravenous antibiotic therapy were examined. In summary the parameters in Table 1 are mostly closer to normal for Frankfurt patients than for Moscow patients. From 1990 to 1995 there were not sufficient data and consequently values and results cannot be considered to be representative. FEV1 values have to be corrected by height, age and sex catego$r^{101,103}$, therefore, they are not directly comparable (for full data, see appendix, Table 10). 

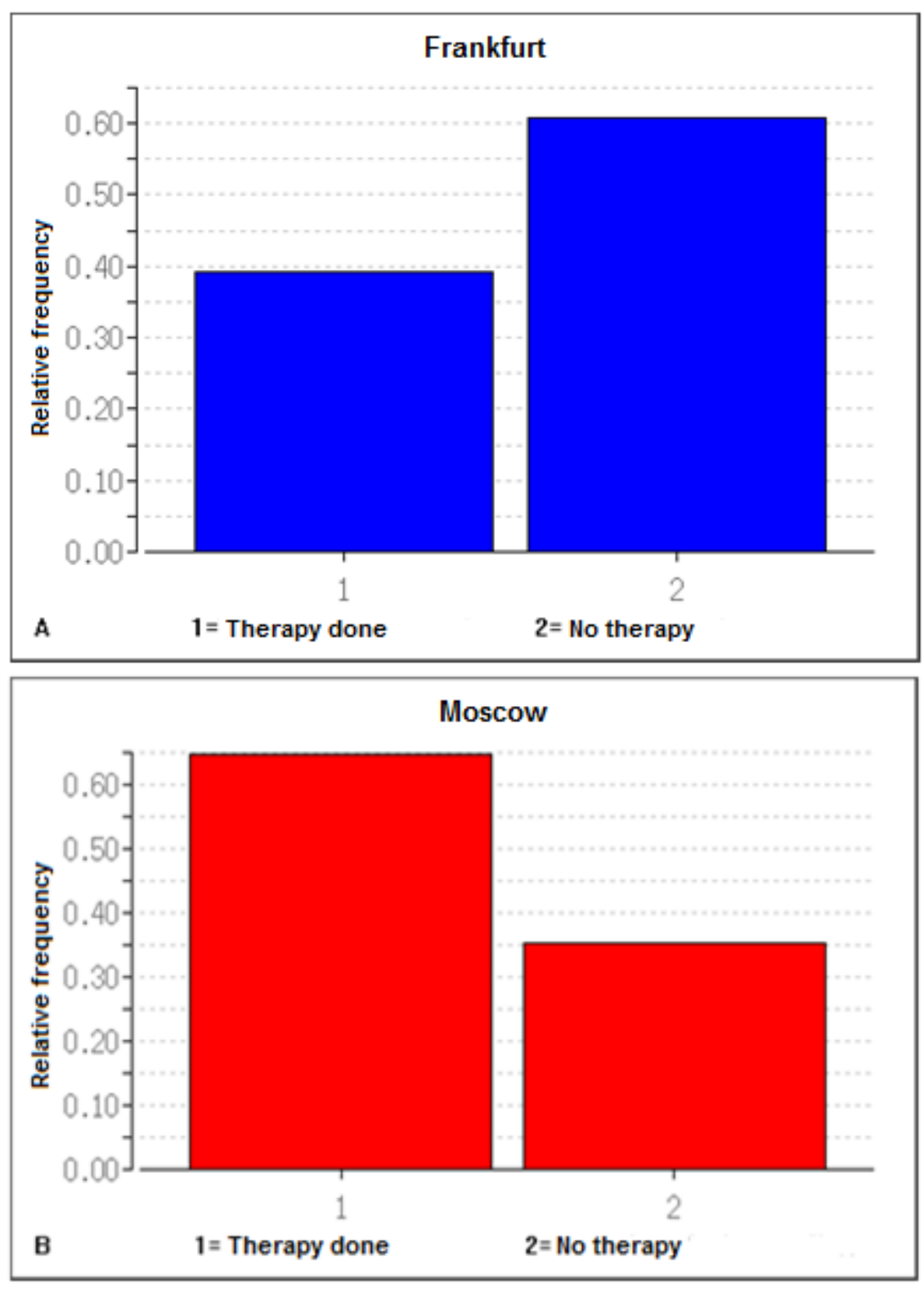

Fig. 4: A) Intravenous antibiotic therapies in Frankfurt in 2015 (relative frequency).

$1=$ Therapy done; $2=$ No therapy.

B) Intravenous antibiotic therapies in Moscow in 2015 (relative frequency). $1=$ Therapy done; $2=$ No therapy.

Intravenous antibiotic therapies in Moscow were carried out more frequently than in Frankfurt in 2015. Intravenous antibiotic therapies are usually done to treat pulmonary exacerbation in CF patients and frequency correlates with number of exacer- 
bations. These differences, however were not statistically significant over a longer period of observation $(p>0,1)$.

\subsection{Comparison of BMI in both CF populations in 2015}

To evaluate if there was a significant statistical difference in BMI between patients in Frankfurt and Moscow, the data set of the year 2015 was analyzed exemplarily. Patients were categorized in age groups.

\section{Patients aged 16 to 18 years:}

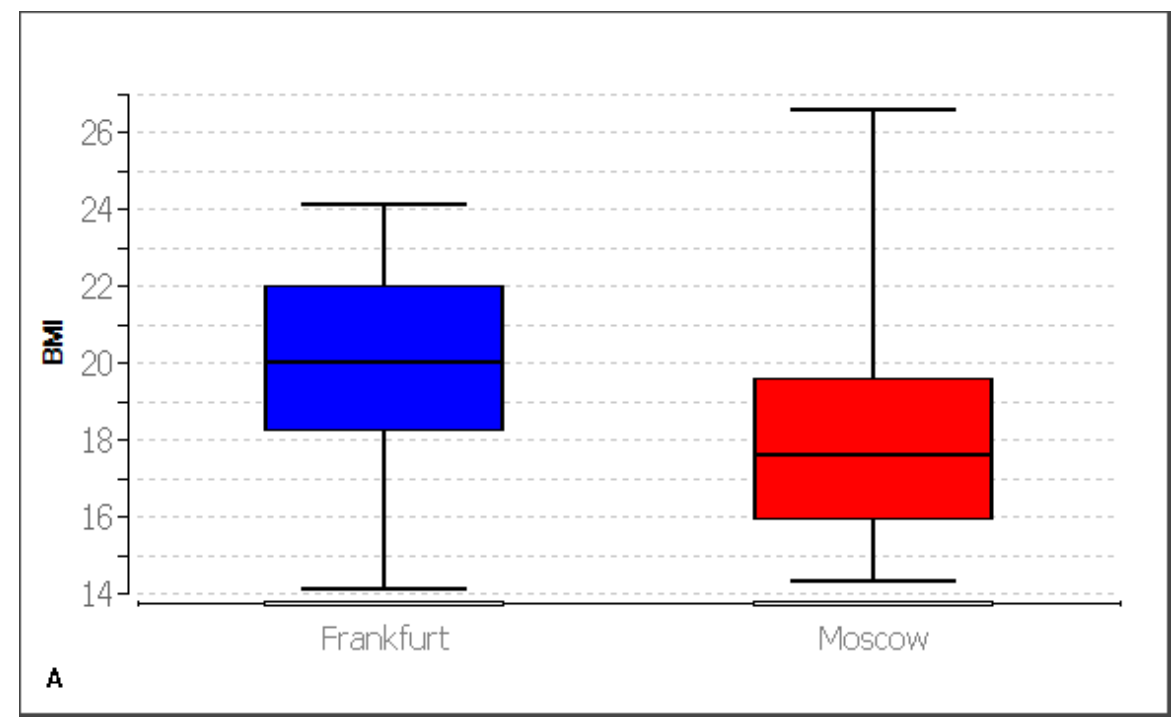

Patients aged 19 to 22 years:

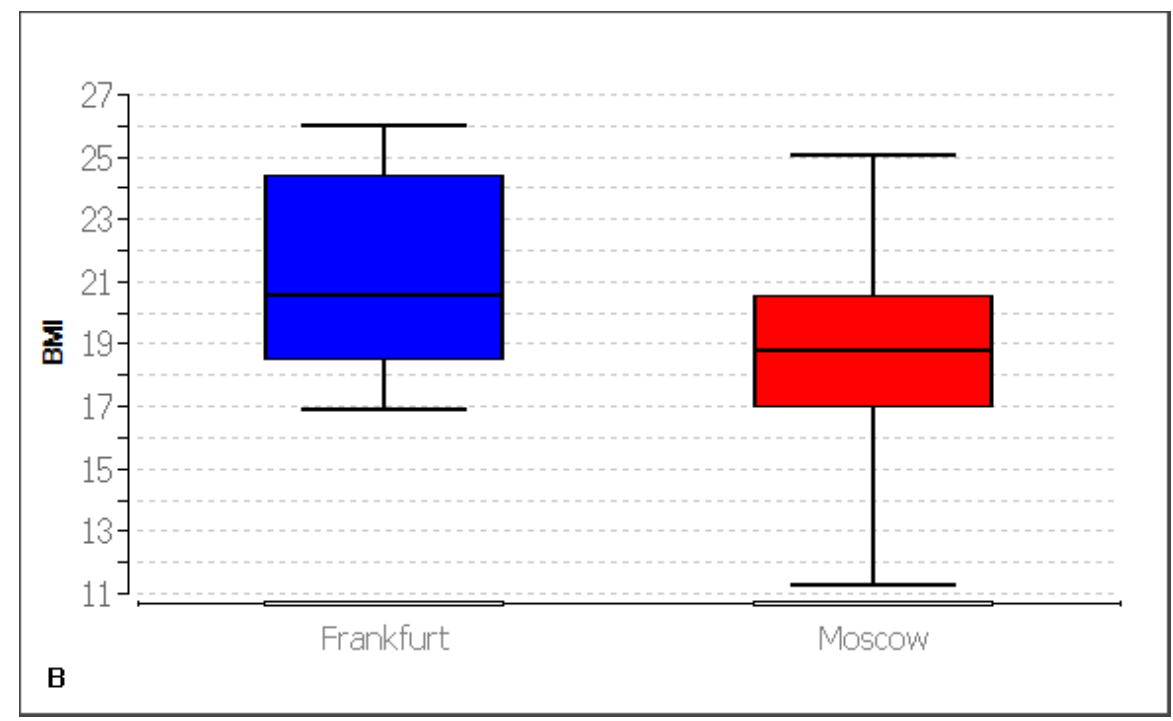


Patients aged 23 to 29 years:

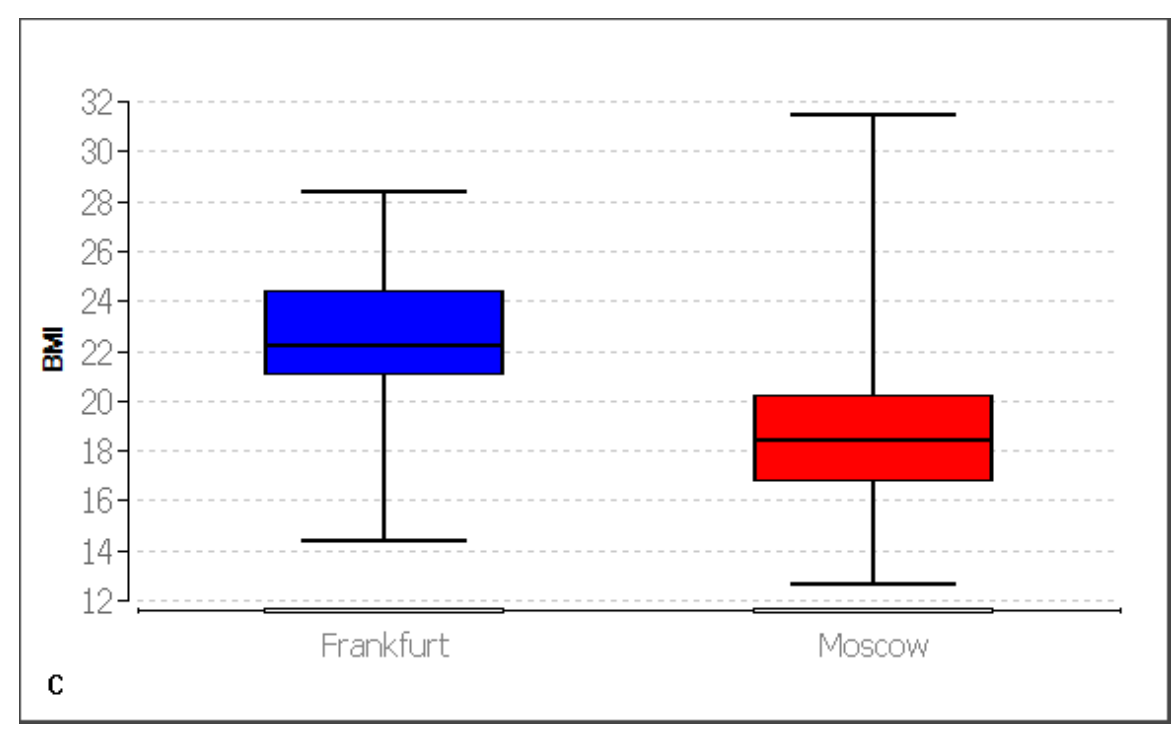

Patients aged 30 to 35 years:

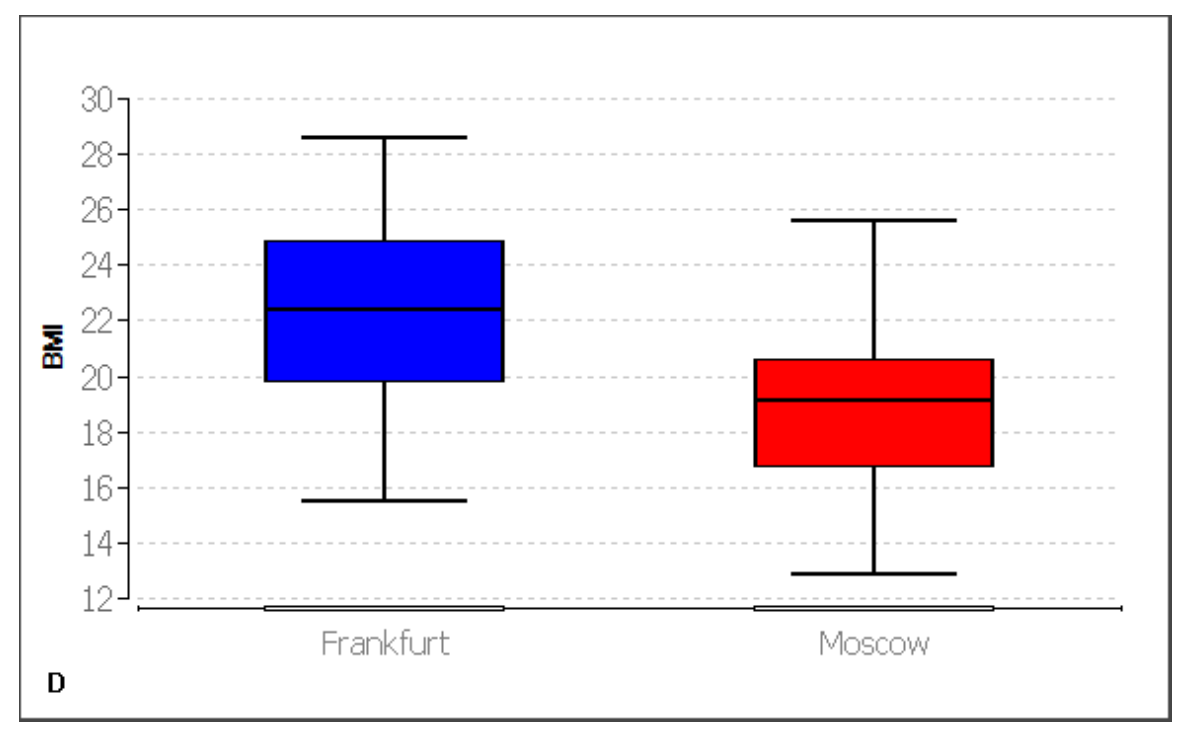


Patients older than 35 years:

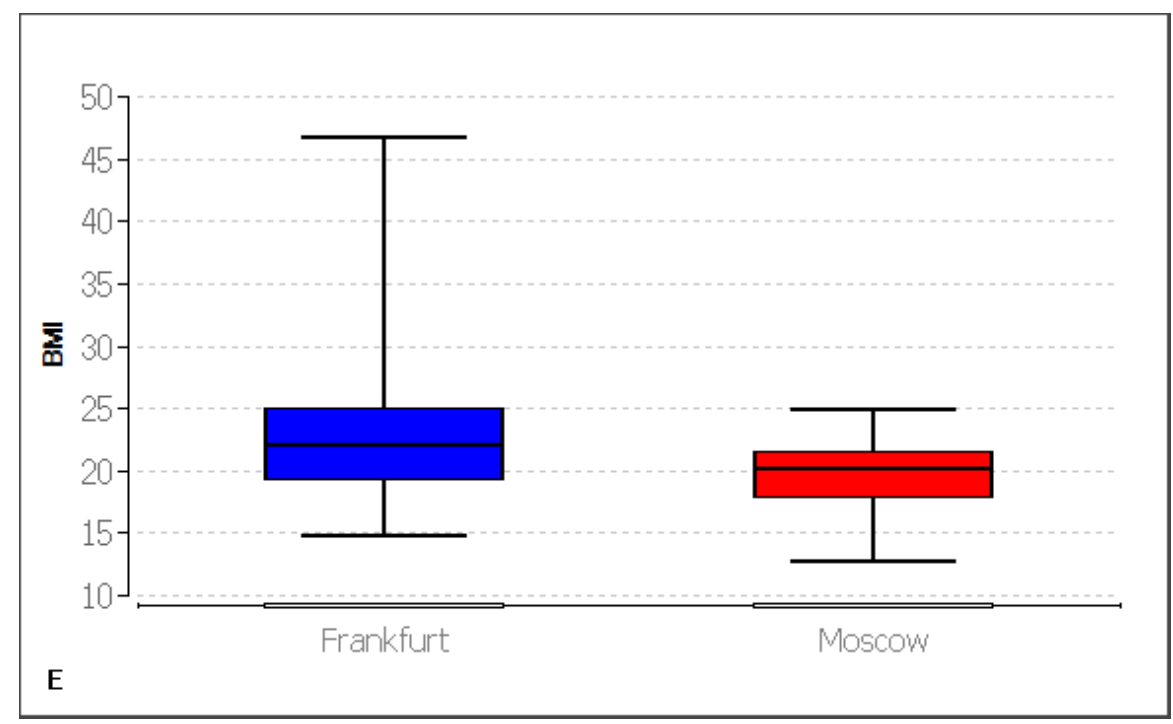

Fig. 5: Box plots representing BMI comparison of patients for 2015 with median, first quartile and third quartile.

A) Patients aged 16 to 18 years (Average BMI: Frankfurt ( $n=12)$ : 19.95; Moscow (n=25): 17.90 - Median BMI: Frankfurt ( $n=12)$ : 19.99; Moscow (n=25): 17.58).

B) Patients aged 19 to 22 years (Average BMI: Frankfurt ( $n=19)$ : 20.87; Moscow (n=76): 18.75 - Median BMI: Frankfurt ( $n=19)$ : 20.56; Moscow (n=76): 18.75).

C) Patients aged 23 to 29 years (Average BMI: Frankfurt ( $n=25)$ : 22.59; Moscow ( $n=139$ ): 18.66 - Median BMI: Frankfurt ( $n=25)$ : 22.22; Moscow (n=139): 18.38).

D) Patients aged 30 to 35 years (Average BMI: Frankfurt ( $n=29$ ): 22.27; Moscow (n=44): 18.97 - Median BMI: Frankfurt ( $n=29)$ : 22.41; Moscow (n=44): 19.14).

E) Patients older than 35 years (Average BMI: Frankfurt ( $n=56$ ): 23.03; Moscow ( $n=17)$ : 19.93 - Median BMI: Frankfurt ( $n=56)$ : 22.03; Moscow $(n=17): 20.08)$.

In 2015 Moscow CF patients stratified by age groups had statistically significant lower BMI than Frankfurt CF patients in all age groups (age 16-18: $p=0.003$; age 
19-22: $p=0.004$; age 23-29: $p<0.001$; age 30-35: $p<0.001$; age 36-66: $p=0.024)^{108-}$ 111.

\subsection{Comparison of FEV1 in matched samples in 2015}

To compare FEV1 in both centers a program run with R-Studio ${ }^{102}$ allowed isolation of samples of matched pairs by height (before matching $p=0.028$, after matching $p=0.876$ ), age (before matching $p<0.001$, after matching $p=0.484$ ) and sex category (before matching $p=0.088$, after matching $p=0.258$ ) for 2015 . Both samples included 100 patients (first sample with 100 Frankfurt patients and second sample with 100 Moscow patients) and were comparable after matching. Statistical analysis showed FEV1 was significantly lower for Moscow CF patients $(p<0.001)$ than for Frankfurt CF patients in 2015.

\begin{tabular}{|l|lllll|}
\hline FEV1 & Average & Median & SD & Maximum & Minimum \\
\hline Frankfurt & 2497.90 & 2420.00 & 1143.19 & 5410.00 & 750.00 \\
Moscow & 1908.70 & 1615.00 & 1044.80 & 5220.00 & 520.00 \\
\hline \multirow{2}{*}{ FEV1 } & Range & quartile & quartile & & \\
\cline { 1 - 2 } Frankfurt & 4660.00 & 1537.50 & 3325.00 & & \\
Moscow & 4700.00 & 1222.50 & 2487.50 & & \\
\cline { 1 - 2 } & & & & & \\
\end{tabular}

Table 4: Biometrical statistical analysis of FEV1 in 2015 for both samples ( $n=100$ CF-patients in Frankfurt and $n=100$ CF-patients in Moscow). Average, median, SD, maximum, minimum, range, first quartile and third quartile are higher in Frankfurt than in Moscow. 


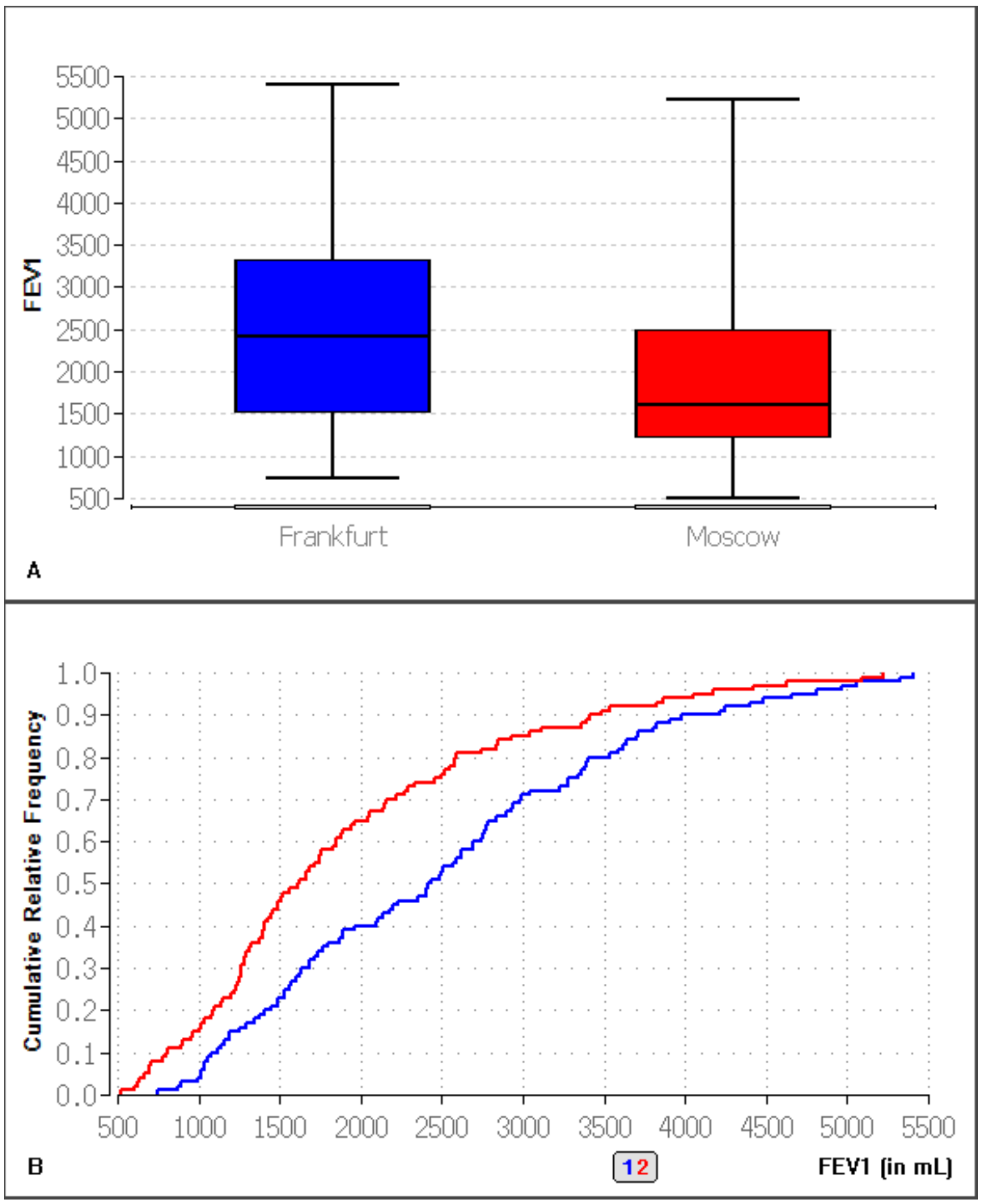

Fig. 6: A) Box plot representing FEV1 comparison of both matched samples for 2015 with median, first quartile and third quartile.

B) Empirical distribution function of FEV1 in both samples (blue=Frankfurt, red=Moscow) for 2015. 


\subsection{BMI comparison with normal population}

\begin{tabular}{|l|l|}
\hline Age group (in years) & Mean BMI \\
\hline $18-20$ & 22.7 \\
\hline $20-25$ & 23.5 \\
\hline $25-30$ & 24.5 \\
\hline $30-35$ & 25.1 \\
\hline $35-40$ & 25.5 \\
\hline $40-45$ & 26.0 \\
\hline $45-50$ & 26.1 \\
\hline $50-55$ & 26.4 \\
\hline $55-60$ & 26.7 \\
\hline $60-65$ & 27.0 \\
\hline $65-70$ & 27.3 \\
\hline $70-75$ & 26.9 \\
\hline$>75$ & 24.5 \\
\hline
\end{tabular}

Table 5: Data from the German federal office of statistics ${ }^{104}$ show mean BMI in Germany for different age categories in 2017. For 18 to 20 year old people the mean BMI was 22.7, in the age group 20 to 25 year BMI was 23.5, while 25 to 30 year old people had a BMI of 24.5. For 30 to 35 year old people it's 25.1. For 35 to 40 year old people it's 25.5. For 40 to 45 year old people it's 26.0. For 45 to 50 year old people it's 26.1. For 50 to 55 year old people it's 26.4. For 55 to 60 year old people it's 26.7 For 60 to 65 year old people it's 27.0. For 65 to 70 year old people it's 27.3. For 70 to 75 year old people it's 26.9. For people elder than 75 years it's 24.5. This leads to a mean BMI of 26.0 for German population.

Russian data ${ }^{105-107}$ are not equally detailed. In 2014 mean BMI in the Russian population was 26.5. In the same year mean BMI was 26.3 in Germany, this might mean that the Russian population has a higher mean BMI than the German population. Consequently gap in BMI in our both CF-populations (referred to 3.4.) cannot be explained by epidemiological data of the normal population. 
3.7. CF quideline comparison between Frankfurt and Moscow

\begin{tabular}{|c|c|c|c|c|}
\hline Field & Question & Guideline $^{43}$ & Moscow & Frankfurt \\
\hline $\begin{array}{l}\text { Hygiene } \\
\text { and pre- } \\
\text { vention }\end{array}$ & $\begin{array}{l}\text { 1. How often } \\
\text { do CF pa- } \\
\text { tients have to } \\
\text { present them- } \\
\text { selves for CF } \\
\text { follow up? }\end{array}$ & $\begin{array}{l}\text { Presentation } \\
\text { every } 1-3 \\
\text { months, ideally } \\
\text { every month. } \\
\text { In newly diag- } \\
\text { nosed children } \\
\text { or patients with } \\
\text { severe illness, } \\
\text { control intervals } \\
<1 \text { month. } \\
\text { With mild CF } \\
\text { presentation } \\
\text { every 3-6 } \\
\text { months. }\end{array}$ & $\begin{array}{l}\text { Presentation } \\
\text { monthly, but in } \\
\text { some cases } \\
\text { only once eve- } \\
\text { ry } 6 \text { months. }\end{array}$ & $\begin{array}{l}\text { CF patients are } \\
\text { routinely seen } \\
\text { every } 3 \text { months } \\
\text { for a check-up at } \\
\text { the CHCF center } \\
\text { (Christiane Her- } \\
\text { zog CF center), } \\
\text { more often if } \\
\text { necessary. } \\
\text { A current referral } \\
\text { slip is required for } \\
\text { treatment at the } \\
\text { CHCF center: } \\
\text { - In adults by the } \\
\text { family doctor; } \\
\text { - For children } \\
\text { from the special- } \\
\text { ist for pediatric } \\
\text { and adolescent } \\
\text { medicine. } \\
\text { Re-appointments } \\
\text { are usually ar- } \\
\text { ranged with the } \\
\text { patient and with } \\
\text { children with the } \\
\text { parents at the } \\
\text { current appoint- } \\
\text { ment. }\end{array}$ \\
\hline
\end{tabular}




\begin{tabular}{|c|c|c|c|c|}
\hline Field & Question & Guideline $^{43}$ & Moscow & Frankfurt \\
\hline & & & & $\begin{array}{l}\text { Appointments } \\
\text { can also be done } \\
\text { by phone or } \\
\text { email. }\end{array}$ \\
\hline $\begin{array}{l}\text { Hygiene } \\
\text { and pre- } \\
\text { vention }\end{array}$ & $\begin{array}{l}\text { 2. Where } \\
\text { must control } \\
\text { be carried } \\
\text { out? }\end{array}$ & $\begin{array}{l}\text { In a designated } \\
\text { clinic / center / } \\
\text { department of a } \\
\text { hospital. }\end{array}$ & $\begin{array}{l}\text { CF center of } \\
\text { the Institute of } \\
\text { Microbiology. }\end{array}$ & $\begin{array}{l}\text { In the CHCF of } \\
\text { the University } \\
\text { Hospital Frank- } \\
\text { furt. }\end{array}$ \\
\hline $\begin{array}{l}\text { Hygiene } \\
\text { and pre- } \\
\text { vention }\end{array}$ & $\begin{array}{l}\text { 3. Who car- } \\
\text { ries out con- } \\
\text { trol? }\end{array}$ & $\begin{array}{l}1 \text { CF doctor and } \\
1 \text { CF nurse } \\
\text { (other depart- } \\
\text { ment employees } \\
\text { must also be } \\
\text { available if re- } \\
\text { quired). }\end{array}$ & $\begin{array}{l}\text { Pneumologist, } \\
\text { cystic fibrosis } \\
\text { specialist. }\end{array}$ & $\begin{array}{l}\text { Specialized hy- } \\
\text { giene officers*. }\end{array}$ \\
\hline $\begin{array}{l}\text { Hygiene } \\
\text { and pre- } \\
\text { vention }\end{array}$ & $\begin{array}{l}\text { 4. What does } \\
\text { the visit / con- } \\
\text { trol include? }\end{array}$ & $\begin{array}{l}\text { Clinical exami- } \\
\text { nation, weight } \\
\text { measurement, } \\
\text { oximetry, age- } \\
\text { related lung } \\
\text { function tests, } \\
\text { decrease in spu- } \\
\text { tum or cough } \\
\text { cultures, } \\
\text { size measure- } \\
\text { ment for chil- } \\
\text { dren and head } \\
\text { circumference } \\
\text { measurement } \\
\text { for very young }\end{array}$ & $\begin{array}{l}\text { Spirometry } \\
\text { (sitting with a } \\
\text { 15-minute } \\
\text { break), aus- } \\
\text { cultation, lung } \\
\text { function test. }\end{array}$ & $\begin{array}{l}\text { > Every } 3 \text { months } \\
\text { (" routine check ** } \\
1 \text { ") are carried } \\
\text { out: } \\
\text { - Physical exami- } \\
\text { nation; } \\
\text { - Further investi- } \\
\text { gations: } \\
\rightarrow \text { In adults: } \\
\text { - Weighing } \\
\text { (weight); } \\
\text { - Microbiology (if } \\
\text { sputum cannot be } \\
\text { coughed up then }\end{array}$ \\
\hline
\end{tabular}




\begin{tabular}{|c|c|c|c|c|}
\hline Field & Question & Guideline $^{43}$ & Moscow & Frankfurt \\
\hline & & children. & & $\begin{array}{l}\text { in; } \\
\text { • Exceptions! } \\
\text { Throat swab, na- } \\
\text { sal swab in } \\
\text { Pseudomonas- } \\
\text { free patients); } \\
\text { - "Small" blood } \\
\text { sampling (includ- } \\
\text { ing blood count } \\
\text { and inflammation } \\
\text { parameter CRP); } \\
\text { - "Small" lung } \\
\text { function } \\
\text { (spirometry). } \\
\text {-In children: } \\
\text { • Weighing } \\
\text { (weight) and body } \\
\text { length; } \\
\text { • Microbiology; } \\
\text { • Blood sampling } \\
\text { (symptom- } \\
\text { oriented outside } \\
\text { the annual check- } \\
\text { up dates); } \\
\text { - Spirometry. }\end{array}$ \\
\hline $\begin{array}{l}\text { Hygiene } \\
\text { and pre- } \\
\text { vention }\end{array}$ & $\begin{array}{l}\text { 5. How is the } \\
\text { control carried } \\
\text { out in patients } \\
\text { with B. }\end{array}$ & $\begin{array}{l}\text { Control on dif- } \\
\text { ferent days or in } \\
\text { separate rooms } \\
\text { / locations / sta- }\end{array}$ & $\begin{array}{l}\text { As in other } \\
\text { cases, but } \\
\text { with anti- } \\
\text { epidemic }\end{array}$ & $\begin{array}{l}\text { Resistant and / or } \\
\text { "special" germs } \\
\text { (e.g. Burkholderia } \\
\text { complex, MRSA, }\end{array}$ \\
\hline
\end{tabular}




\begin{tabular}{|c|c|c|c|c|}
\hline Field & Question & Guideline $^{43}$ & Moscow & Frankfurt \\
\hline & $\begin{array}{l}\text { cepacia com- } \\
\text { plex, MRSA } \\
\text { or P. } \\
\text { aeruginosa } \\
\text { (Place / time } \\
\text { especially } \\
\text { with several } \\
\text { affected pa- } \\
\text { tients)? }\end{array}$ & tions. & measures. & $\begin{array}{l}\text { non-tuberculous } \\
\text { mycobacteria of } \\
\text { the Abscessus } \\
\text { type, } \\
\text { multiresistantly } \\
\text { defined germs } \\
\text { such as 4MRGN): } \\
\text { - A spatial germ } \\
\text { separation is car- } \\
\text { ried out in the CF } \\
\text { center; } \\
\text { - Access to CF } \\
\text { ambulance via } \\
\text { entrance } 18 \text { (see } \\
\text { access to CF } \\
\text { ambulance for P. } \\
\text { aeruginosa pa- } \\
\text { tients via en- } \\
\text { trance } 18 \mathrm{~A} \text { ); } \\
\text { - The staff also } \\
\text { wear a face } \\
\text { mask, a protec- } \\
\text { tive coat and pro- } \\
\text { tective gloves, } \\
\text { when they have } \\
\text { contact with pa- } \\
\text { tients. }\end{array}$ \\
\hline $\begin{array}{l}\text { Hygiene } \\
\text { and pre- } \\
\text { vention }\end{array}$ & $\begin{array}{l}\text { 6. Accessibil- } \\
\text { ity of the CF } \\
\text { center? }\end{array}$ & $\begin{array}{l}\text { Patients can call } \\
\text { the CF Center } \\
24 \text { hours a day }\end{array}$ & $\begin{array}{l}\text { Accessibility in } \\
\text { Moscow from } \\
5 \text { minutes to } 1\end{array}$ & $\begin{array}{l}\text { Patients can call } \\
\text { the CF Center for } \\
24 \text { hours a day }\end{array}$ \\
\hline
\end{tabular}




\begin{tabular}{|c|c|c|c|c|}
\hline Field & Question & Guideline $^{43}$ & Moscow & Frankfurt \\
\hline & & $\begin{array}{l}\text { for a medical } \\
\text { presentation. } \\
\text { Emergency vis- } \\
\text { its can happen } \\
\text { through direct } \\
\text { contact. } \\
\text { It is also rec- } \\
\text { ommended that } \\
\text { a CF specialist } \\
\text { nurse is availa- } \\
\text { ble to answer } \\
\text { patient ques- } \\
\text { tions at certain } \\
\text { times. }\end{array}$ & $\begin{array}{l}\text { hour. From } \\
\text { Vladivostok: } \\
12 \text { hours flight } \\
\text { time. }\end{array}$ & $\begin{array}{l}\text { for medical con- } \\
\text { sultation or } \\
\text { emergencies } \\
\text { At certain times, } \\
\text { a CF-specialized } \\
\text { doctor or a CF- } \\
\text { specialized nurse } \\
\text { is available for } \\
\text { patient inquiries } \\
\rightarrow \text { Not carried out } \\
\text { yet in Frankfurt, } \\
\text { but soon (current- } \\
\text { ly a bronchosco- } \\
\text { py doctor from } \\
\text { the CF team is } \\
\text { always available - } \\
\text { he can call in the } \\
\text { "right" CF doc- } \\
\text { tor) }{ }^{*} \text {. }\end{array}$ \\
\hline $\begin{array}{l}\text { Hygiene } \\
\text { and pre- } \\
\text { vention }\end{array}$ & $\begin{array}{l}\text { 7. Is there an } \\
\text { infection / hy- } \\
\text { giene team? }\end{array}$ & $\begin{array}{l}\text { Infection and } \\
\text { hygiene team } \\
\text { for infection con- } \\
\text { trol must be } \\
\text { available. }\end{array}$ & $\begin{array}{l}\text { Infection and } \\
\text { hygiene spe- } \\
\text { cialists availa- } \\
\text { ble. }\end{array}$ & $\begin{array}{l}\text { Infection and hy- } \\
\text { giene team for } \\
\text { infection control } \\
\text { available. }\end{array}$ \\
\hline $\begin{array}{l}\text { Hygiene } \\
\text { and pre- } \\
\text { vention }\end{array}$ & $\begin{array}{l}\text { 8. Bed distri- } \\
\text { bution? }\end{array}$ & $\begin{array}{l}\text { Beds must be in } \\
\text { single rooms to } \\
\text { prevent cross- } \\
\text { infection or } \\
\text { transmission of } \\
\text { germs between }\end{array}$ & $\begin{array}{l}20 \text { single } \\
\text { rooms availa- } \\
\text { ble at the } \\
\text { same time } \\
\text { with a waiting } \\
\text { time of } 1 \text { to } 7\end{array}$ & $\begin{array}{l}\text { Beds are orga- } \\
\text { nized in single } \\
\text { rooms, own toilet } \\
\text { and bathroom } \\
\text { available per bed/ } \\
\text { room*. }\end{array}$ \\
\hline
\end{tabular}




\begin{tabular}{|c|c|c|c|c|}
\hline Field & Question & Guideline $^{43}$ & Moscow & Frankfurt \\
\hline & & $\begin{array}{l}\text { patients. } \\
\text { It is also rec- } \\
\text { ommended to } \\
\text { have an own } \\
\text { toilet and bath- } \\
\text { room per bed/ } \\
\text { room. }\end{array}$ & $\begin{array}{l}\text { days. } \\
\text { Own toilet and } \\
\text { shower are } \\
\text { available. }\end{array}$ & \\
\hline $\begin{array}{l}\text { Hygiene } \\
\text { and pre- } \\
\text { vention }\end{array}$ & $\begin{array}{l}\text { 9. Hygiene } \\
\text { and } \\
\text { disinfectant } \\
\text { presence? }\end{array}$ & $\begin{array}{l}\text { Hand washing } \\
\text { facilities (e.g. } \\
\text { wash basins) in } \\
\text { every patient } \\
\text { cabin available, } \\
\text { as well as alco- } \\
\text { hol-based disin- } \\
\text { fectants and } \\
\text { detergents } \\
\text { available. }\end{array}$ & $\begin{array}{l}\text { Detergents } \\
\text { and disinfect- } \\
\text { ants are avail- } \\
\text { able (washba- } \\
\text { sins and disin- } \\
\text { fectants with } \\
\text { alcohol). }\end{array}$ & $\begin{array}{l}\text { Hand washing } \\
\text { facilities (e.g. } \\
\text { wash basins) in } \\
\text { every patient cab- } \\
\text { in, } \\
\text { as well as alco- } \\
\text { hol-based disin- } \\
\text { fectants and de- } \\
\text { tergents availa- } \\
\text { ble*. }\end{array}$ \\
\hline $\begin{array}{l}\text { Hygiene } \\
\text { and pre- } \\
\text { vention }\end{array}$ & $\begin{array}{l}\text { 10. Separa- } \\
\text { tion from B. } \\
\text { cepacia com- } \\
\text { plex or MRSA } \\
\text { patients? }\end{array}$ & $\begin{array}{l}\text { Must be handled } \\
\text { at different sta- } \\
\text { tions to prevent } \\
\text { transmission. } \\
\text { B. cepacia pa- } \\
\text { tients: } \\
\text { - Must be treat- } \\
\text { ed in separate } \\
\text { rooms, also to } \\
\text { avoid transmis- } \\
\text { sion; }\end{array}$ & $\begin{array}{l}\text { Patients are } \\
\text { separated. }\end{array}$ & $\begin{array}{l}\text { Patients are } \\
\text { treated at differ- } \\
\text { ent wards (but } \\
\text { actually in the } \\
\text { same ward due to } \\
\text { lack of space) to } \\
\text { prevent transmis- } \\
\text { sion. } \\
\text { B. cepacia pa- } \\
\text { tients: } \\
\text { - Treated in sepa- }\end{array}$ \\
\hline
\end{tabular}




\begin{tabular}{|c|c|c|c|c|}
\hline Field & Question & Guideline $^{43}$ & Moscow & Frankfurt \\
\hline & & $\begin{array}{l}\text { - Not meeting of } \\
\text { patients in hos- } \\
\text { pitals (transmis- } \\
\text { sion prevention); } \\
\text { - Social contacts } \\
\text { outside the hos- } \\
\text { pital with B. } \\
\text { cepacia must be } \\
\text { avoided (trans- } \\
\text { mission preven- } \\
\text { tion). }\end{array}$ & & $\begin{array}{l}\text { rate rooms, also } \\
\text { to avoid transfers; } \\
\text { - Cannot meet } \\
\text { each other in the } \\
\text { hospital (trans- } \\
\text { mission preven- } \\
\text { tion); } \\
\text { - Have to avoid } \\
\text { social contacts } \\
\text { outside the hospi- } \\
\text { tal with B. } \\
\text { cepacia-infected } \\
\text { patients (trans- } \\
\text { mission preven- } \\
\text { tion). }\end{array}$ \\
\hline $\begin{array}{l}\text { Hygiene } \\
\text { and pre- } \\
\text { vention }\end{array}$ & $\begin{array}{l}\text { 11. Assess- } \\
\text { ment of hy- } \\
\text { perglycaemia } \\
\text { and cross- } \\
\text { night oxygen } \\
\text { saturation } \\
\text { when ingest- } \\
\text { ed? }\end{array}$ & $\begin{array}{l}\text { With each ad- } \\
\text { mission, hyper- } \\
\text { glycaemia and } \\
\text { cross-night oxy- } \\
\text { gen saturation } \\
\text { must be as- } \\
\text { sessed during } \\
\text { the event of in- } \\
\text { fection exacer- } \\
\text { bations. }\end{array}$ & $\begin{array}{l}\text { Hyperglycae- } \\
\text { mia is as- } \\
\text { sessed with } \\
\text { each new ad- } \\
\text { mission. }\end{array}$ & $\begin{array}{l}\text { Assessment of } \\
\text { hyperglycaemia } \\
\text { and cross-night } \\
\text { oxygen saturation } \\
\text { in the case of } \\
\text { infectious exac- } \\
\text { erbations per- } \\
\text { formed with each } \\
\text { admission*. }\end{array}$ \\
\hline $\begin{array}{l}\text { Hygiene } \\
\text { and pre- } \\
\text { vention }\end{array}$ & $\begin{array}{l}\text { 12. Sputum } \\
\text { analysis and } \\
\text { spirometry? }\end{array}$ & $\begin{array}{l}\text { Perform sputum } \\
\text { analysis and } \\
\text { spirometry once }\end{array}$ & $\begin{array}{l}\text { Performed } \\
\text { sputum analy- } \\
\text { sis and }\end{array}$ & $\begin{array}{l}\text { Sputum analysis } \\
\text { and spirometry } \\
\text { performed once a }\end{array}$ \\
\hline
\end{tabular}




\begin{tabular}{|c|c|c|c|c|}
\hline Field & Question & Guideline $^{43}$ & Moscow & Frankfurt \\
\hline & & a week. & $\begin{array}{l}\text { spirometry } \\
\text { once a week. }\end{array}$ & week*. \\
\hline $\begin{array}{l}\text { Hygiene } \\
\text { and pre- } \\
\text { vention }\end{array}$ & $\begin{array}{l}\text { 13. Annual } \\
\text { assessment? }\end{array}$ & $\begin{array}{l}\text { An annual as- } \\
\text { sessment must } \\
\text { be carried out to } \\
\text { enable the suc- } \\
\text { cess of the ther- } \\
\text { apy. }\end{array}$ & $\begin{array}{l}\text { Annual as- } \\
\text { sessment is } \\
\text { carried out. }\end{array}$ & $\begin{array}{l}\text { Annual assess- } \\
\text { ment is carried } \\
\text { out. }\end{array}$ \\
\hline $\begin{array}{l}\text { Therapy } \\
\text { indication }\end{array}$ & $\begin{array}{l}\text { 1. Patient } \\
\text { consultation / } \\
\text { review? }\end{array}$ & $\begin{array}{l}\text { Discussion of } \\
\text { the inpatient } \\
\text { care patients } \\
\text { and i.v. antibi- } \\
\text { otic outpatient } \\
\text { care (currently } \\
\text { at home) pa- } \\
\text { tients at least } \\
\text { once a week in } \\
\text { a multidiscipli- } \\
\text { nary consulta- } \\
\text { tion with all } \\
\text { members of the } \\
\text { CF team, as } \\
\text { well as the doc- } \\
\text { tors and nurses } \\
\text { on the ward. }\end{array}$ & $\begin{array}{l}\text { There are } \\
\text { nurses on the } \\
\text { ward. }\end{array}$ & $\begin{array}{l}\text { Discussion of the } \\
\text { inpatient care and } \\
\text { i.v. antibiotic out- } \\
\text { patient care pa- } \\
\text { tients at least } \\
\text { once a week in a } \\
\text { multidisciplinary } \\
\text { consultation with } \\
\text { all members of } \\
\text { the CF team, as } \\
\text { well as the doc- } \\
\text { tors and nurses } \\
\text { on ward*. }\end{array}$ \\
\hline $\begin{array}{l}\text { Therapy } \\
\text { indication }\end{array}$ & $\begin{array}{l}\text { 2. Antibiotic } \\
\text { treatment af- } \\
\text { ter pulmonary } \\
\text { exacerbation? }\end{array}$ & $\begin{array}{l}\text { Depending on } \\
\text { the clinical } \\
\text { course, we rec- } \\
\text { ommend prima- } \\
\text { ry intravenous }\end{array}$ & $\begin{array}{l}\text { Primarily i.v. } \\
\text { therapy, fol- } \\
\text { lowed by inha- } \\
\text { lation therapy. }\end{array}$ & $\begin{array}{l}\text { Depending on the } \\
\text { clinical course: } \\
\text { primarily intrave- } \\
\text { nous therapy in } \\
\text { patients with }\end{array}$ \\
\hline
\end{tabular}




\begin{tabular}{|c|c|c|c|c|}
\hline Field & Question & Guideline $^{43}$ & Moscow & Frankfurt \\
\hline & & $\begin{array}{l}\text { therapy in pa- } \\
\text { tients with pul- } \\
\text { monary exacer- } \\
\text { bation combined } \\
\text { with subsequent } \\
\text { inhalation thera- } \\
\text { py with colistin / } \\
\text { ciprofloxacin } \\
\text { p.o. or tobramy- } \\
\text { cin. }\end{array}$ & & $\begin{array}{l}\text { pulmonary exac- } \\
\text { erbation com- } \\
\text { bined with a sub- } \\
\text { sequent inhala- } \\
\text { tion therapy with } \\
\text { colistin / ciprof- } \\
\text { loxacin p.o. or } \\
\text { tobramycin. This } \\
\text { is patient-specific } \\
\text { That may apply, } \\
\text { but does not have } \\
\text { to*. }\end{array}$ \\
\hline $\begin{array}{l}\text { Therapy } \\
\text { indication }\end{array}$ & $\begin{array}{l}\text { 3. What ther- } \\
\text { apy is re- } \\
\text { quired if the } \\
\text { attempt of } \\
\text { eradication } \\
\text { wasn't suc- } \\
\text { cessful? }\end{array}$ & $\begin{array}{l}\text { If a first eradica- } \\
\text { tion cycle is un- } \\
\text { successful, the } \\
\text { following thera- } \\
\text { py alternatives } \\
\text { should be con- } \\
\text { sidered: } \\
\text { - An i.v. colistin } \\
\text { therapy over } 2 \\
\text { weeks or thera- } \\
\text { py with } \\
\text { inhalated } \\
\text { colistin plus high } \\
\text { dose oral ciprof- } \\
\text { loxacin (3x } 2 \\
\text { million IU) } \\
\text { - Later: oral } \\
\text { ciprofloxacin for }\end{array}$ & $\begin{array}{l}\text { I.v. therapy for } \\
2-3 \text { weeks or } \\
\text { inhalation } \\
\text { therapy in } \\
\text { combination } \\
\text { with oral ther- } \\
\text { apy. If these } \\
\text { approaches } \\
\text { are unsuc- } \\
\text { cessful too: } \\
\text { switch to other } \\
\text { antibiotic } \\
\text { combinations }\end{array}$ & $\begin{array}{l}\text { If an initial eradi- } \\
\text { cation cycle is } \\
\text { unsuccessful: } \\
\text { - An i.v. colistin } \\
\text { therapy over } 2 \\
\text { weeks or high } \\
\text { dose inhalated } \\
\text { colistin plus high } \\
\text { dose (3x } 2 \text { million } \\
\text { IU) oral ciproflox- } \\
\text { acin } \\
\text { - Later: oral } \\
\text { ciprofloxacin for } 3 \\
\text { months } \\
\text { or inhaled tobra- } \\
\text { mycin in a dose } \\
\text { of } 2 x 300 \text { mg } \\
\text { over } 4 \text { weeks. }\end{array}$ \\
\hline
\end{tabular}




\begin{tabular}{|c|c|c|c|c|}
\hline Field & Question & Guideline $^{43}$ & Moscow & Frankfurt \\
\hline & & $\begin{array}{l}3 \text { months } \\
\text { or inhaled to- } \\
\text { bramycin in a } \\
\text { dose of } 2 x 300 \\
\text { mg over } 4 \\
\text { weeks. } \\
\text { If inhalation is } \\
\text { not possible, the } \\
\text { i.v. therapy } \\
\text { should be re- } \\
\text { peated over } 14 \\
\text { days and possi- } \\
\text { bly other combi- } \\
\text { nations can be } \\
\text { used (expert } \\
\text { opinion). }\end{array}$ & & $\begin{array}{l}\text { If inhalation is not } \\
\text { possible: } \\
\text { - I.v. therapy re- } \\
\text { peated over } 14 \\
\text { days and possibly } \\
\text { others antibiotic } \\
\text { combinations. } \\
\rightarrow \text { In Frankfurt, } \\
\text { treatment is } \\
\text { based on the } \\
\text { newest guide- } \\
\text { line*. }\end{array}$ \\
\hline
\end{tabular}




\begin{tabular}{|c|c|c|c|c|}
\hline Field & Question & Guideline $^{43}$ & Moscow & Frankfurt \\
\hline Therapy & $\begin{array}{l}\text { 1. Start of } \\
\text { treatment and } \\
\text { treatment } \\
\text { conditions? }\end{array}$ & $\begin{array}{l}\text { Clinical or do- } \\
\text { mestic i.v. anti- } \\
\text { biotic therapy } \\
\text { can be orga- } \\
\text { nized in 24-48h. } \\
\text { Initial dose } \\
\text { (starting dose) } \\
\text { of antibiotic i.v. } \\
\text { therapy super- } \\
\text { vised/ monitored } \\
\text { by medical staff. }\end{array}$ & $\begin{array}{l}\text { Clinical or } \\
\text { home antibi- } \\
\text { otic therapy. }\end{array}$ & $\begin{array}{l}\text { Clinical or do- } \\
\text { mestic i.v. antibi- } \\
\text { otic therapy or- } \\
\text { ganized in 24- } \\
48 \mathrm{~h} . \\
\text { Initial dose (start- } \\
\text { ing dose) of anti- } \\
\text { biotic i.v. therapy } \\
\text { supervised/ moni- } \\
\text { tored by medical } \\
\text { staff*. }\end{array}$ \\
\hline Therapy & $\begin{array}{l}\text { 2. Availability } \\
\text { of physiother- } \\
\text { apists, dieti- } \\
\text { tians and so- } \\
\text { cial workers? }\end{array}$ & $\begin{array}{l}\text { Monitoring and } \\
\text { therapy by phys- } \\
\text { iotherapists, die- } \\
\text { titians, social } \\
\text { workers and } \\
\text { other in therapy } \\
\text { involved staff } \\
\text { must be availa- } \\
\text { ble }\end{array}$ & $\begin{array}{l}\text { Supervision by } \\
\text { various medi- } \\
\text { cal specialists. }\end{array}$ & $\begin{array}{l}\text { Monitoring and } \\
\text { therapy by physi- } \\
\text { otherapists, dieti- } \\
\text { tians, social } \\
\text { workers and oth- } \\
\text { er in therapy in- } \\
\text { volved staff avail- } \\
\text { able.* }\end{array}$ \\
\hline
\end{tabular}




\begin{tabular}{|c|c|c|c|c|}
\hline Field & Question & Guideline $^{43}$ & Moscow & Frankfurt \\
\hline Therapy & $\begin{array}{l}3 . \\
\text { Physiotherapy } \\
\text { and sputum } \\
\text { mobilization? }\end{array}$ & $\begin{array}{l}\text { Sputum mobili- } \\
\text { zation therapy } \\
\text { and physiother- } \\
\text { apy should be } \\
\text { performed } 2 \\
\text { times a day. }\end{array}$ & $\begin{array}{l}\text { It is depending } \\
\text { on the state of } \\
\text { patients' } \\
\text { health: physio- } \\
\text { therapy, sport. }\end{array}$ & $\begin{array}{l}\text { Depending on the } \\
\text { state of patients' } \\
\text { health: sputum } \\
\text { mobilization ther- } \\
\text { apy and physio- } \\
\text { therapy are car- } \\
\text { ried out twice a } \\
\text { day for patients } \\
\text { with poor health, } \\
\text { and sport is rec- } \\
\text { ommended for } \\
\text { "healthier" pa- } \\
\text { tients*. }\end{array}$ \\
\hline Therapy & $\begin{array}{l}\text { 4. Equipment } \\
\text { for checking } \\
\text { physical activ- } \\
\text { ities and ther- } \\
\text { apy monitor- } \\
\text { ing? }\end{array}$ & $\begin{array}{l}\text { Therapy moni- } \\
\text { toring for phys- } \\
\text { iotherapy, such } \\
\text { as pulse } \\
\text { oximetry and } \\
\text { oxygen inhalers, } \\
\text { must be availa- } \\
\text { ble. }\end{array}$ & $\begin{array}{l}\text { Pulse oximetry } \\
\text { is available. }\end{array}$ & $\begin{array}{l}\text { Therapy monitor- } \\
\text { ing for physio- } \\
\text { therapy, such as } \\
\text { pulse oximetry } \\
\text { and inhalation } \\
\text { devices are } \\
\text { available*. }\end{array}$ \\
\hline Therapy & $\begin{array}{l}\text { 5. Logging of } \\
\text { antibiotic } \\
\text { therapy? }\end{array}$ & $\begin{array}{l}\text { Protocols about: } \\
\text { - Administration } \\
\text { and dosage of } \\
\text { the antibiotics } \\
\text { must be availa- } \\
\text { ble (including } \\
\text { measurements } \\
\text { of the } \\
\text { Blood serum }\end{array}$ & $\begin{array}{l}\text { Protocols } \\
\text { about: } \\
\text { - Condition, } \\
\text { dosage of an- } \\
\text { tibiotics, blood } \\
\text { sugar etc. . }\end{array}$ & $\begin{array}{l}\text { Protocols about: } \\
\text { - Administration } \\
\text { and dosage of } \\
\text { the antibiotics are } \\
\text { done (including } \\
\text { measurements of } \\
\text { the } \\
\text { Blood serum } \\
\text { concentration of }\end{array}$ \\
\hline
\end{tabular}




\begin{tabular}{|c|c|c|c|c|}
\hline Field & Question & Guideline $^{43}$ & Moscow & Frankfurt \\
\hline & & $\begin{array}{l}\text { concentration of } \\
\text { antibiotics). }\end{array}$ & & (antibiotics) ${ }^{*}$. \\
\hline Therapy & $\begin{array}{l}\text { 6. Communi- } \\
\text { cation be- } \\
\text { tween CF } \\
\text { center and } \\
\text { "home clinic"? }\end{array}$ & $\begin{array}{l}\text { Satellite CF cen- } \\
\text { ter (used espe- } \\
\text { cially if travel } \\
\text { distance to the } \\
\text { actual CF center } \\
\text { is too wide for } \\
\text { patients affected } \\
\text { to be visited } \\
\text { regularly) must } \\
\text { permit to have a } \\
\text { look after at } \\
\text { least } 20 \text { CF pa- } \\
\text { tients and must } \\
\text { include special- } \\
\text { ized CF dieti- } \\
\text { tians, CF physi- } \\
\text { otherapists and } \\
\text { CF nurses. }\end{array}$ & $\begin{array}{l}\text { Pneumologists } \\
\text { in conjunction } \\
\text { with cystic } \\
\text { fibrosis spe- } \\
\text { cialists are } \\
\text { available in } \\
\text { satellite CF } \\
\text { centers. }\end{array}$ & $\begin{array}{l}\text { Frankfurt has no } \\
\text { satellite outpa- } \\
\text { tient clinics and is } \\
\text { certified as a } \\
\text { "single center"*. }\end{array}$ \\
\hline Therapy & $\begin{array}{l}\text { 7. Standards } \\
\text { in the satellite } \\
\text { CF center? }\end{array}$ & $\begin{array}{l}\text { An equivalent } \\
\text { standard to the } \\
\text { main CF center } \\
\text { must be availa- } \\
\text { ble. }\end{array}$ & $\begin{array}{l}\text { It is depending } \\
\text { on intellectual } \\
\text { reserve, wish- } \\
\text { es and finan- } \\
\text { cial regional } \\
\text { means. }\end{array}$ & - \\
\hline Therapy & $\begin{array}{l}\text { 8. Control of } \\
\text { patients in the } \\
\text { satellite CF } \\
\text { center? }\end{array}$ & $\begin{array}{l}\text { The team at the } \\
\text { main CF center } \\
\text { has to see pa- } \\
\text { tients } 1-2 \text { times }\end{array}$ & $\begin{array}{l}\text { Presentation } \\
\text { of patients at } \\
\text { the main CF } \\
\text { center in Mos- }\end{array}$ & - \\
\hline
\end{tabular}




\begin{tabular}{|c|c|c|c|c|}
\hline Field & Question & Guideline $^{43}$ & Moscow & Frankfurt \\
\hline & & $\begin{array}{l}\text { a year (either by } \\
\text { introducing the } \\
\text { patient to the } \\
\text { main CF center } \\
\text { or by visits by } \\
\text { main CF center } \\
\text { staff in the satel- } \\
\text { lite CF center). }\end{array}$ & $\begin{array}{l}\text { cow 1-2 times } \\
\text { a year. }\end{array}$ & \\
\hline Therapy & $\begin{array}{l}\text { 9. When does } \\
\text { the transition } \\
\text { of CF child } \\
\text { care to CF } \\
\text { care for adult } \\
\text { patients oc- } \\
\text { curs? }\end{array}$ & $\begin{array}{l}\text { Usually it occurs } \\
\text { between } 16 \text { and } \\
18 \text { years, de- } \\
\text { pending on } \\
\text { health status } \\
\text { and social ma- } \\
\text { turity. }\end{array}$ & $\begin{array}{l}\text { There are } 4 \\
\text { CF centers for } \\
\text { children in } \\
\text { Moscow. The } \\
\text { children are } \\
\text { observed up } \\
\text { to } 18 \text { years } \\
\text { and then sup- } \\
\text { ported in adult } \\
\text { CF centers. }\end{array}$ & - \\
\hline Therapy & $\begin{array}{l}\text { 10. Is there } \\
\text { any coopera- } \\
\text { tion between } \\
\text { pediatric and } \\
\text { adult CF cen- } \\
\text { ters? }\end{array}$ & $\begin{array}{l}\text { Close coopera- } \\
\text { tion is mandato- } \\
\text { ry between pe- } \\
\text { diatric and adult } \\
\text { CF centers to } \\
\text { enable the de- } \\
\text { velopment, up- } \\
\text { date and revi- } \\
\text { sion of therapy } \\
\text { guidelines. }\end{array}$ & $\begin{array}{l}\text { There is a } \\
\text { very close co- } \\
\text { operation be- } \\
\text { tween both } \\
\text { types of CF } \\
\text { centers. }\end{array}$ & - \\
\hline
\end{tabular}




\begin{tabular}{|c|c|c|c|c|}
\hline Field & Question & Guideline $^{43}$ & Moscow & Frankfurt \\
\hline Therapy & $\begin{array}{l}\text { 11. Which } \\
\text { antibiotic re- } \\
\text { sistance are } \\
\text { tested? }\end{array}$ & $\begin{array}{l}\text { First choice: } \\
\text { piperacillin, } \\
\text { ceftazidime, } \\
\text { meropenem, } \\
\text { tobramycin, } \\
\text { ciprofloxacin, } \\
\text { colistin /// Se- } \\
\text { cond choice: } \\
\text { piperacillin- } \\
\text { tazobactam, } \\
\text { cefepim, gen- } \\
\text { tamicin, } \\
\text { amikacin, } \\
\text { aztreonam, } \\
\text { fosfomycin, } \\
\text { doripenem }\end{array}$ & $\begin{array}{l}\text { Resistance is } \\
\text { always tested } \\
\text { for all of them. }\end{array}$ & - \\
\hline Therapy & $\begin{array}{l}\text { 12. Are there } \\
\text { antibiotic } \\
\text { treatment op- } \\
\text { tions for pa- } \\
\text { tients with } \\
\text { Pseudo- } \\
\text { monas in the } \\
\text { lower air- } \\
\text { ways? }\end{array}$ & $\begin{array}{l}\text { Recommenda- } \\
\text { tion: } \\
\text { - Early eradica- } \\
\text { tion with inhaled } \\
\text { tobramycin for } 4 \\
\text { weeks or oral } \\
\text { ciprofloxacin } \\
\text { combined with } \\
\text { inhaled colistin } \\
\text { for } 3 \text { weeks; } \\
\text { - If inhalation is } \\
\text { not possible, } \\
\text { intravenous } \\
\text { combination }\end{array}$ & $\begin{array}{l}\text { Early eradica- } \\
\text { tion therapy: } \\
\text { - Inhalation } \\
\text { first. If this } \\
\text { remains un- } \\
\text { successful } \\
\text { i.v. therapy } \\
\text { or inhalative } \\
\text { and i.v. thera- } \\
\text { py in combina- } \\
\text { tion should be } \\
\text { tested. }\end{array}$ & $\begin{array}{l}\text { Early eradication } \\
\text { with: } \\
\text { - Inhaled tobra- } \\
\text { mycin for } 4 \\
\text { weeks or oral } \\
\text { ciprofloxacin } \\
\text { combined with } \\
\text { inhaled colistin } \\
\text { for } 3 \text { weeks. } \\
\text { - If inhalation isn't } \\
\text { possible, intrave- } \\
\text { nous combination } \\
\text { therapy has to be } \\
\text { carried out. }\end{array}$ \\
\hline
\end{tabular}




\begin{tabular}{|c|c|c|c|c|}
\hline Field & Question & Guideline $^{43}$ & Moscow & Frankfurt \\
\hline & & $\begin{array}{l}\text { therapy should } \\
\text { be considered. }\end{array}$ & & \\
\hline Therapy & $\begin{array}{l}\text { 13. Is there } \\
\text { any adjust- } \\
\text { ment of anti- } \\
\text { biotic therapy } \\
\text { according to } \\
\text { patients' age? }\end{array}$ & Reference $\mathrm{N}^{\circ} 1$. & $\begin{array}{l}\text { Therapy } \\
\text { scheme ac- } \\
\text { cording to ref- } \\
\text { erence } N^{\circ} 1 \text {. }\end{array}$ & $\begin{array}{l}\text { Therapy scheme } \\
\text { according to ref- } \\
\text { erence } N^{\circ} 1^{*} \text {. }\end{array}$ \\
\hline Therapy & $\begin{array}{l}\text { 14. Should } \\
\text { patients in- } \\
\text { hale with hy- } \\
\text { pertonic sa- } \\
\text { line or with } \\
\text { Dornase alfa? }\end{array}$ & $\begin{array}{l}\text { It is recom- } \\
\text { mended that } \\
\text { regardless of PA } \\
\text { colonization, an } \\
\text { individual deci- } \\
\text { sion whether } \\
\text { inhalation of } \\
\text { Dornase alfa or } \\
\text { hypertonic sa- } \\
\text { line has to be } \\
\text { done or not. }\end{array}$ & $\begin{array}{l}\text { Inhalation of } \\
\text { Dornase alfa } \\
\text { or hypertonic } \\
\text { saline is done } \\
\text { in individual } \\
\text { cases regard- } \\
\text { less of Pseu- } \\
\text { domonas } \\
\text { aeruginosa } \\
\text { infection*. }\end{array}$ & $\begin{array}{l}\text { Inhalation of } \\
\text { Dornase alfa or } \\
\text { inhalation with } \\
\text { hypertonic saline } \\
\text { done in individual } \\
\text { cases regardless } \\
\text { of Pseudomonas } \\
\text { aeruginosa infec- } \\
\text { tion*. }\end{array}$ \\
\hline
\end{tabular}




\begin{tabular}{|l|l|l|l|l|}
\hline Field & Question & Guideline $^{43}$ & Moscow & Frankfurt \\
\hline \hline Therapy & 15. Should & It is recom- & Physiotherapy & Physiotherapy \\
& physiotherapy & mended that CF & and sport & (or/and sport - \\
& and sport be & patients start & must be start- & depending on \\
& started after & with physiother- & ed as early as & age) is started as \\
& initial PA & apy and (de- & possible. & early as possible \\
& presence? & pending on age) & & after diagnosis \\
& & sport regardless & & regardless of \\
& of PA coloniza- & & Pseudomonas \\
& tion, as early as & & aeruginosa colo- \\
& possible after & & nization*. \\
& diagnosis. & & \\
\hline
\end{tabular}

* Information from Dr. Smaczny

** 1: Once a year, a so-called "annual check-up" is carried out instead of the "routine check"

Reference $N^{\circ} 1$ : As far as possible, inhalation therapy is strived for young children. Children under 3 years of age usually inhale through a mask. If inhalation is not possible, intravenous antibiotic therapy can be used. Tobramycin inhalation is carried out with $2 \times 80 \mathrm{mg}$ to $2 \times 300 \mathrm{mg}$. The tobramycin inhalation takes place in patients older than 6 years with tobramycin $2 x 300 \mathrm{mg}$ in on/ off mode for 28 days each. In Germany, inhalation is also common with tobramycin carried out with $2 x$ $80 \mathrm{mg}$, with a continuous inhalation without off mode. Therapy with ciprofloxacin orally can start with $40 \mathrm{mg} / \mathrm{kg}$ per day in the first month of life. In some centers, colistin inhalation is increased according to a step-by-step scheme or with higher dose after repeated pathogen detection: It starts with $2 \times 1$ million for 3 weeks at first detection. If the pathogen is detected again, it is increased to $3 \times 2$ million, also over 3 weeks. With each additional pathogen detection, the same dosage and extension of the inhalation for 3 months is indicated. If the eradication attempt with inhaled and oral antibiotics is unsuccessful or if there is a pulmonary exacerbation 
at the initial detection, an intravenous antibiotic therapy usually in a combination of aminopenicillins with a third generation cephalosporins should be administrated. ${ }^{112}$

Table 6: Application of $\mathrm{CF}^{43}$ guidelines in Frankfurt and Moscow. Guidelines about outpatient care in blue, inpatient care in pink and lower respiratory tract infection in yellow, empty fields in gray.

This table is based on internationally proposed guidelines ${ }^{43}$. It shows how the international guidelines are implemented in both centers and what resources are available. The standardized operational procedures (SOPs) in Frankfurt and Moscow were reported according to the local center directives ${ }^{112}$ and interviews with local experts. Many differences can be noticed and are discussed below.

\section{Discussion}

\section{Design of the study}

Different studies have shown that prognosis in CF is related to Body-Mass-Index $(\mathrm{BMI})^{89}$, Forced Expiratory Volume in 1 second $(\mathrm{FEV} 1)^{90}$, and need of intravenous antibiotic therapy ${ }^{43}$. They have significant impact on survival and the quality of life of CF patients ${ }^{91}$ and are widespread used for CF studies. This is why we decided to pick up these three parameters for our study and to compare their values between both CF centers.

At first we had to analyze epidemiological available data of normal population to see if both are reasonably comparable. Latest data from the German federal office of statistics ${ }^{104}$ shows a mean BMI of 26.0 for German population in 2017. Russian data $^{105-107}$ are not equally detailed and latest data was published in 2014. Mean $\mathrm{BMI}$ in the Russian population was 26.5. In the same year mean BMI was 26.3 in Germany, this might mean that the Russian population has a higher mean BMI than the German population, however both populations can be considered comparable. Consequently a possible gap in BMI in both CF-populations (referred to 3.4.) cannot be explained by epidemiological data of the normal population. 
Available data from CF patients according to European Cystic Fibrosis Patient Registry (ECFSPR) annual report in 2017 show country gaps for CF parameters. A comparison of BMI in $2017^{3}$ between Germany and the Russian Federation in the table below shows a difference for patients categorized in age and sex groups. Average and mean values are closer to normal in Germany for adults (men and women).

\begin{tabular}{|c|c|c|}
\hline & Mean BMI & $\begin{array}{l}\text { Median } \mathrm{BMI}(50 \% \text { of the } \\
\text { patients are below this } \\
\mathrm{BMI})\end{array}$ \\
\hline $\begin{array}{l}\text { Germany (Patients aged } \\
18 \text { years or older) }\end{array}$ & 21.50 & 21.10 \\
\hline $\begin{array}{l}\text { Russian Federation (Pa- } \\
\text { tients aged } 18 \text { years or } \\
\text { older) }\end{array}$ & 19.60 & 19.10 \\
\hline $\begin{array}{l}\text { Germany (Male patients } \\
\text { aged } 18 \text { years or older) }\end{array}$ & 21.90 & 21.60 \\
\hline $\begin{array}{l}\text { Russian Federation } \\
\text { (Male patients aged } 18 \\
\text { years or older) }\end{array}$ & 20.00 & 19.40 \\
\hline $\begin{array}{l}\text { Germany (Female pa- } \\
\text { tients aged } 18 \text { years or } \\
\text { older) }\end{array}$ & 21.00 & 20.50 \\
\hline $\begin{array}{l}\text { Russian Federation } \\
\text { (Female patients aged } 18 \\
\text { years or older) }\end{array}$ & 19.10 & 18.70 \\
\hline
\end{tabular}

Table 7: BMI: descriptive statistics ${ }^{3}$, comparison by country, age and sex groups, 2017.

In summary, according to ECFSPR annual report of 2017 the BMI of Germany and the Russian Federation are different. German patients' BMI is higher than that of Russian patients, this is true for patients older than 18 years, regardless of whether 
female or male. Furthermore $\mathrm{BMI}^{89}$ is a significant surrogate marker for $\mathrm{CF}$ lifetime prognosis, what increases the importance of this value.

Another important CF marker is the FEV1\%. It is a significant surrogate marker ${ }^{90}$ for CF overall prognosis of survival with a high grade importance. A comparison of FEV1\% between Germany and the Russian Federation in the table below shows a difference for patients categorized in age groups. Average and mean values seem higher in Germany for children and for adults, a statistical analysis of the published data could not be done.

\begin{tabular}{|l|l|l|}
\hline & Average FEV1\% (mean) & $\begin{array}{l}\text { Median (50\% of patients } \\
\text { have a FEV1 below this } \\
\text { value) }\end{array}$ \\
\hline $\begin{array}{l}\text { Germany (Patients aged } \\
\text { 6-17 years who have } \\
\text { never had a lung trans- } \\
\text { plant.) }\end{array}$ & 90.1 & $\mathbf{9 2 . 5}$ \\
\hline $\begin{array}{l}\text { Russian Federation (Pa- } \\
\text { tients aged 6-17 years } \\
\text { who have never had a } \\
\text { lung transplant.) }\end{array}$ & 82.9 & $\mathbf{8 3 . 9}$ \\
\hline $\begin{array}{l}\text { Germany (Patients aged } \\
18 \text { years or older who } \\
\text { have never had a lung } \\
\text { transplant.) }\end{array}$ & 65.4 & 65.6 \\
\hline $\begin{array}{l}\text { Russian Federation (Pa- } \\
\text { tients aged 18 years or } \\
\text { older who have never had } \\
\text { a lung transplant.) }\end{array}$ & 57.5 & $\mathbf{5 5 . 3}$ \\
\hline
\end{tabular}

Table 8: FEV1\%: descriptive statistics ${ }^{3}$, comparison by country and age groups, 2017. 
The values grouped in the two figures below show the FEV $1 \%$ in different age groups for both countries in 2017 . The dot shows the median. The first quartile and third quartile are represented by the whiskers. The country quartiles are blue; the pooled quartiles calculated for the 2017 ECFSPR annual report ${ }^{3}$ regrouping the whole ECFS countries are in red and represent the pooled quartiles on all other countries (i.e. excluding the country compared).

\section{Quartiles of $\mathrm{FEV}_{1} \%$ : Germany}

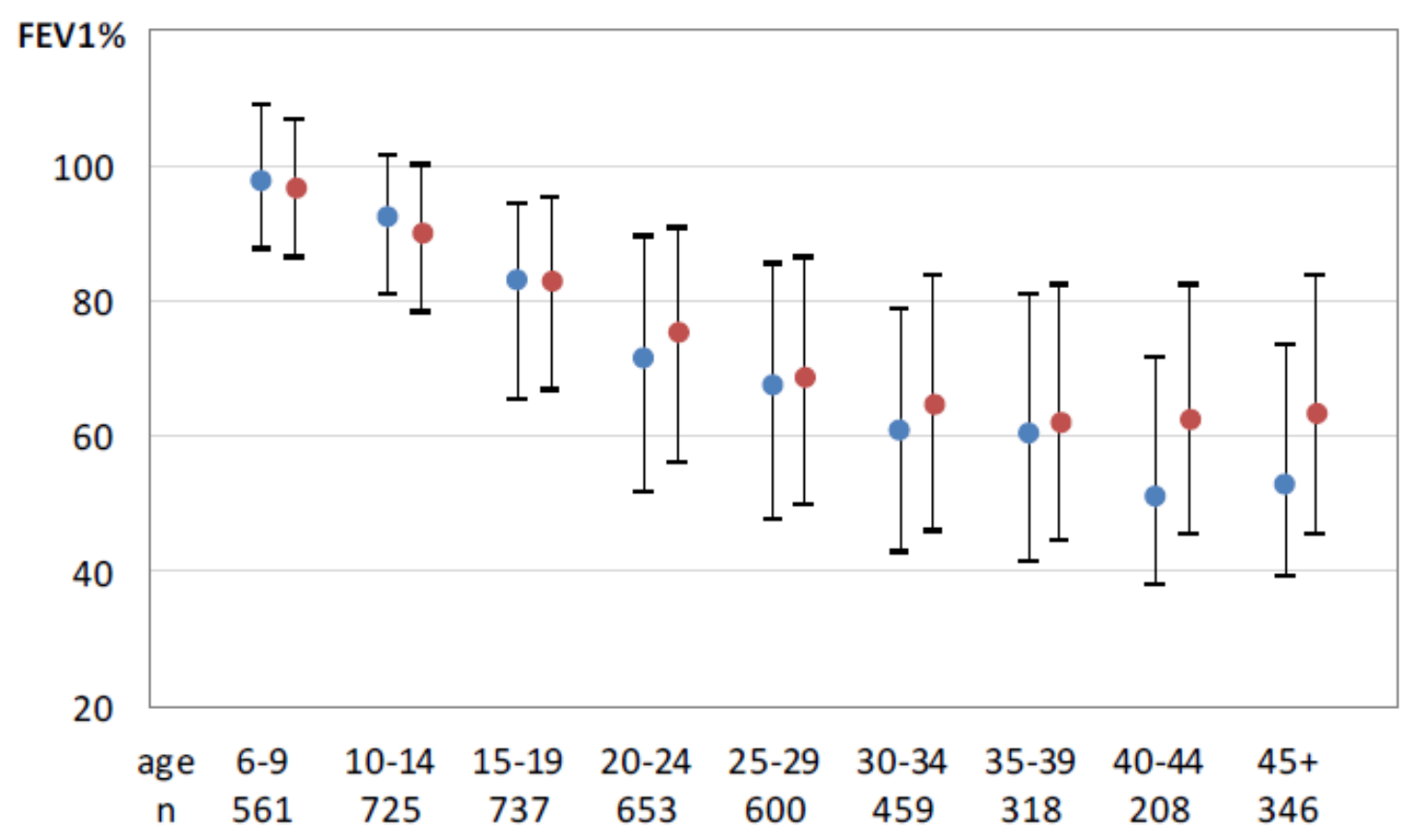

Fig. 7: The values show the FEV1\% in different age groups for Germany and the other ECFS countries ${ }^{3}$. The quartiles of Germany are blue; the pooled quartiles regrouping the whole ECFS countries except the data from Germany are in red.

From 6 to 39 years Germany's data is comparable with the pooled data. For patients 40 years and older Germany's FEV1\% values seem to be lower than the FEV $1 \%$ values of the other ECFS states. 


\section{Quartiles of $\mathrm{FEV}_{1} \%$ : Russian Federation}

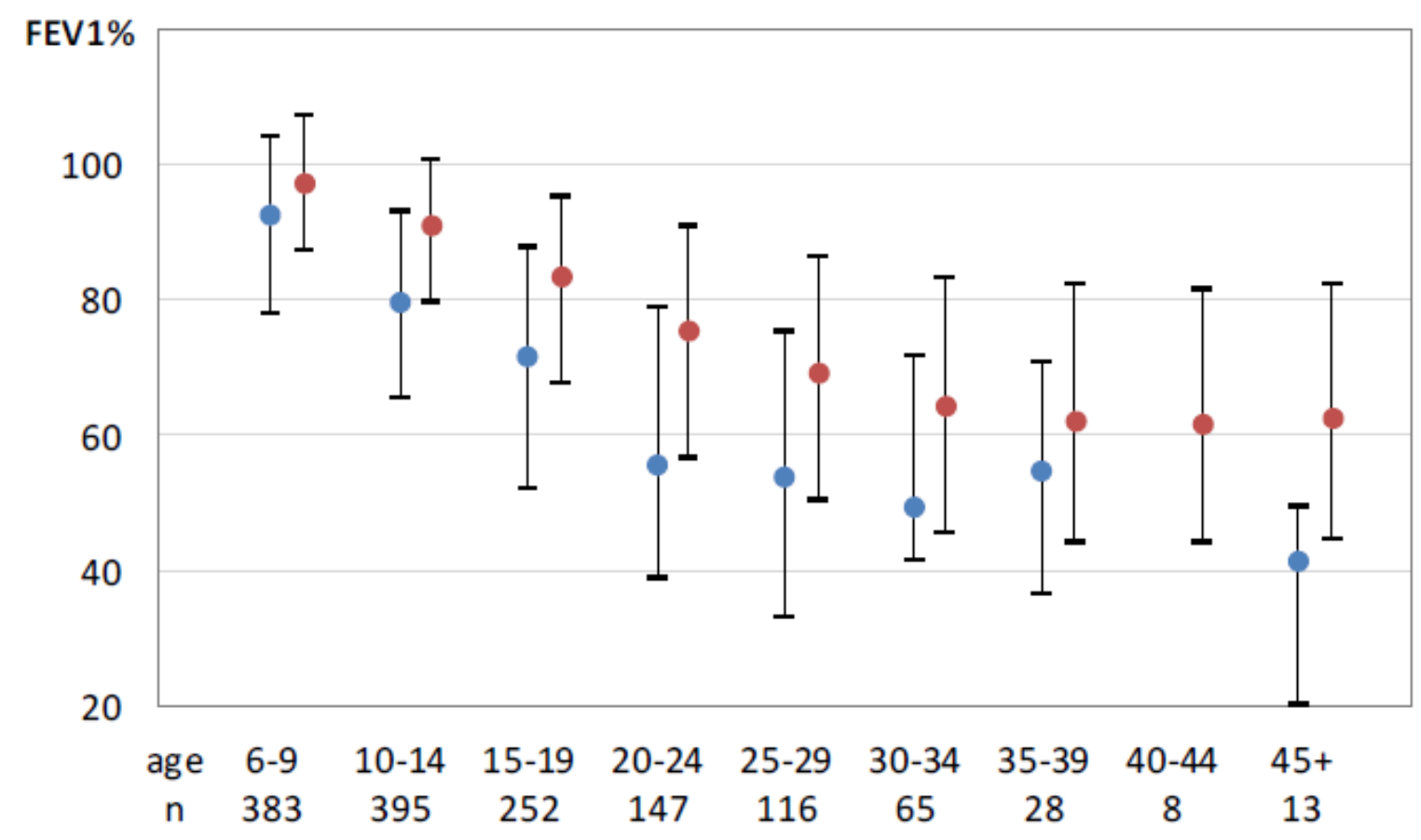

Fig. 8: The values show the FEV1\% in different age groups for the Russian Federation and the other ECFS countries ${ }^{3}$. The quartiles of the Russian Federation are blue; the pooled quartiles regrouping the whole ECFS countries except the data from patients from the Russian Federation are in red.

In all age categories Russian FEV1\% values seem to be lower than the FEV1\% values of the other ECFS countries. For the age category 40 to 44 years data is missing and no comparison could be established.

In summary, according to ECFSPR annual report of 2017 the FEV1\% of Germany and the Russian Federation are different. German data seem to resemble the pooled data very closely, while the Russian data seem to be lower than pooled data and German data. This is the reason why we expected differences between both centers we wanted to analyze.

Finally, a third parameter was collected: the presence of chronic Pseudomonas aeruginosa in CF patients. This parameter has a direct influence on CF patient 
survival and is very important because it is linked to the necessity of intravenous antibiotic therapy, which is a surrogate parameter. Prognosis in CF depends on the need of intravenous antibiotic therapy as a result of a severe pulmonal exacerbation ${ }^{61}$ or a chronic $P$. aeruginosa infection ${ }^{96}$. In the table below the chronic $P$. aeruginosa prevalence was determined in adults and children for the year 2017.

\begin{tabular}{|l|l|l|l|}
\hline $\begin{array}{l}\text { Number of chronic } \\
\text { Pseudomonas } \\
\text { aeruginosa infection } \\
\text { observed in Germany }\end{array}$ & 278 & Positive (Yes) & Negative (No) \\
\hline $\begin{array}{l}\text { Prevalence of chronic } \\
\text { Pseudomonas }\end{array}$ & 3736 & 2105 \\
$\begin{array}{l}\text { aeruginosa infection } \\
\text { observed in Germany } \\
\text { (in \%) }\end{array}$ & 4.54 & 61.06 & 34.40 \\
\hline $\begin{array}{l}\text { Number of_chronic } \\
\text { Pseudomonas } \\
\text { aeruginosa infection } \\
\text { observed in the Rus- } \\
\text { sian Federation }\end{array}$ & 96 & 2020 & 964 \\
\hline $\begin{array}{l}\text { Prevalence of chronic } \\
\text { Pseudomonas } \\
\text { aeruginosa infection } \\
\text { observed in the Rus- } \\
\text { sian Federation (in } \\
\text { \%) }\end{array}$ & 3.12 & 65.58 & 31.30 \\
\hline
\end{tabular}




\begin{tabular}{|c|c|c|c|}
\hline $\begin{array}{l}\text { Number of chronic } \\
\text { Pseudomonas } \\
\underline{\text { aeruginosa infection }} \\
\text { in children seen in } \\
\text { Germany }\end{array}$ & 70 & 2231 & 260 \\
\hline $\begin{array}{l}\text { Prevalence of chronic } \\
\text { Pseudomonas } \\
\underline{\text { aeruginosa infection }} \\
\text { in children seen in } \\
\text { Germany (in \%) }\end{array}$ & 2.73 & 87.11 & 10.15 \\
\hline $\begin{array}{l}\text { Number of chronic } \\
\text { Pseudomonas } \\
\underline{\text { aeruginosa infection }} \\
\text { in children seen in the } \\
\text { Russian Federation }\end{array}$ & 49 & 1715 & 612 \\
\hline $\begin{array}{l}\text { Prevalence of chronic } \\
\text { Pseudomonas } \\
\underline{\text { aeruginosa infection }} \\
\text { in children seen in the } \\
\text { Russian Federation } \\
\text { (in \%) }\end{array}$ & 2.06 & 72.18 & 25.76 \\
\hline $\begin{array}{l}\text { Number of chronic } \\
\text { Pseudomonas } \\
\frac{\text { aeruginosa infection }}{\text { in adults seen in }} \\
\text { Germany }\end{array}$ & 208 & 1505 & 1845 \\
\hline $\begin{array}{l}\text { Prevalence of chronic } \\
\text { Pseudomonas } \\
\underline{\text { aeruginosa infection }} \\
\text { in adults seen in } \\
\text { Germany (in \%) }\end{array}$ & 5.85 & 42.30 & 51.85 \\
\hline
\end{tabular}




\begin{tabular}{|c|c|c|c|}
\hline $\begin{array}{l}\text { Number of chronic } \\
\text { Pseudomonas } \\
\underline{\text { aeruginosa infection }} \\
\text { in adults seen in the } \\
\text { Russian Federation }\end{array}$ & 47 & 305 & 352 \\
\hline $\begin{array}{l}\text { Prevalence of chronic } \\
\text { Pseudomonas } \\
\text { aeruginosa infection } \\
\text { in adults seen in the } \\
\text { Russian Federation } \\
\text { (in \%) }\end{array}$ & 6.68 & 43.32 & 50.00 \\
\hline
\end{tabular}

Table 9: Prevalence of chronic bacterial infection in all patients seen in $2017^{3}$, by country.

To get a better overview of these numbers the prevalence is represented in histograms below. 


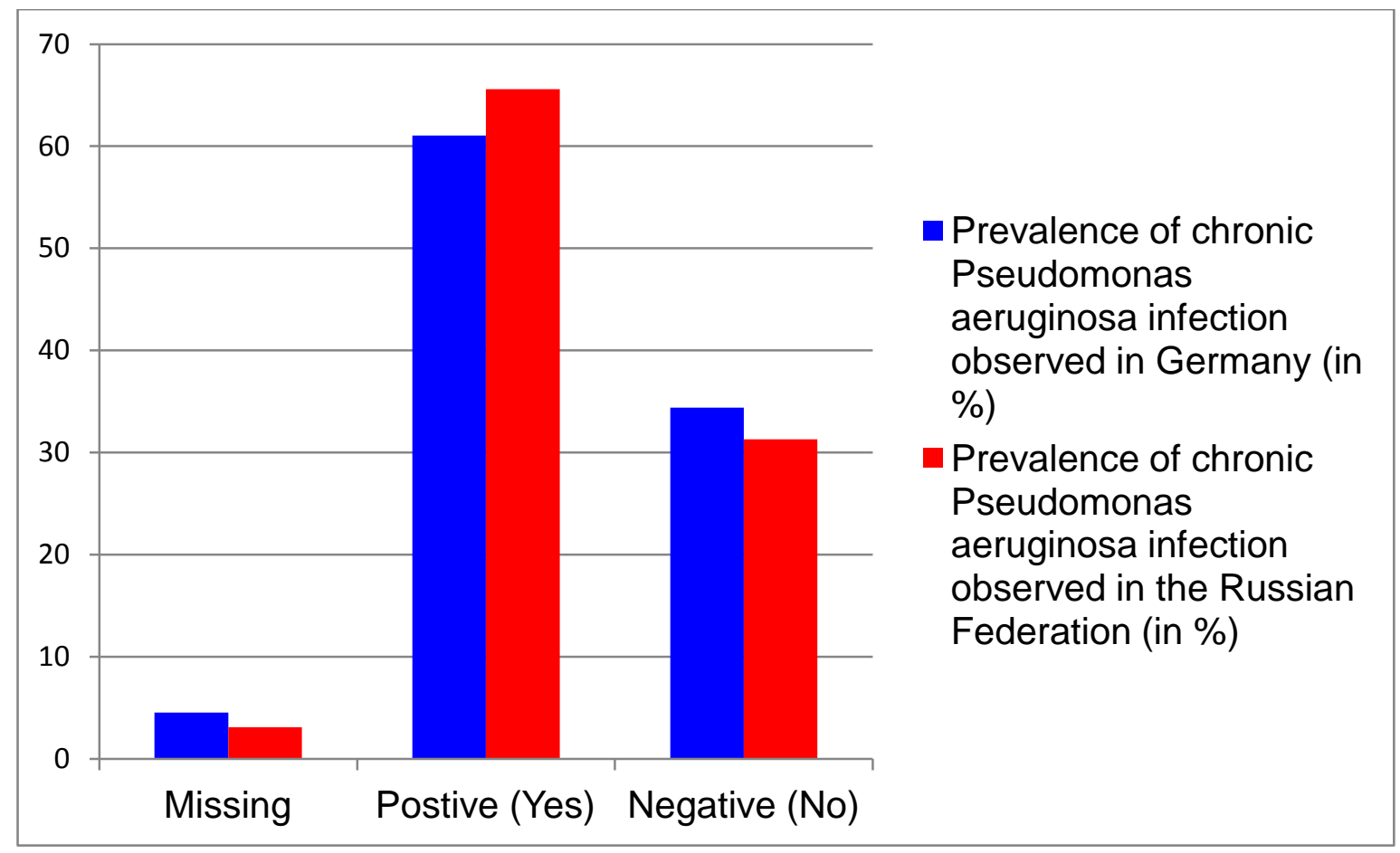

Fig. 9: Prevalence of chronic Pseudomonas aeruginosa infection observed in Germany and the Russian Federation (in \%).

According to ECFSPR annual report of $2017^{3}$, we could observe the prevalence of chronic $P$. aeruginosa infection in both countries is quite similar. The rate of missing values is below 5 percent in both countries. The rate of presence of P.aeruginosa in all patients is above 60 percent in both countries and seems to be a little higher in the Russian Federation (65.58\%), compared to Germany (61.06\%). 


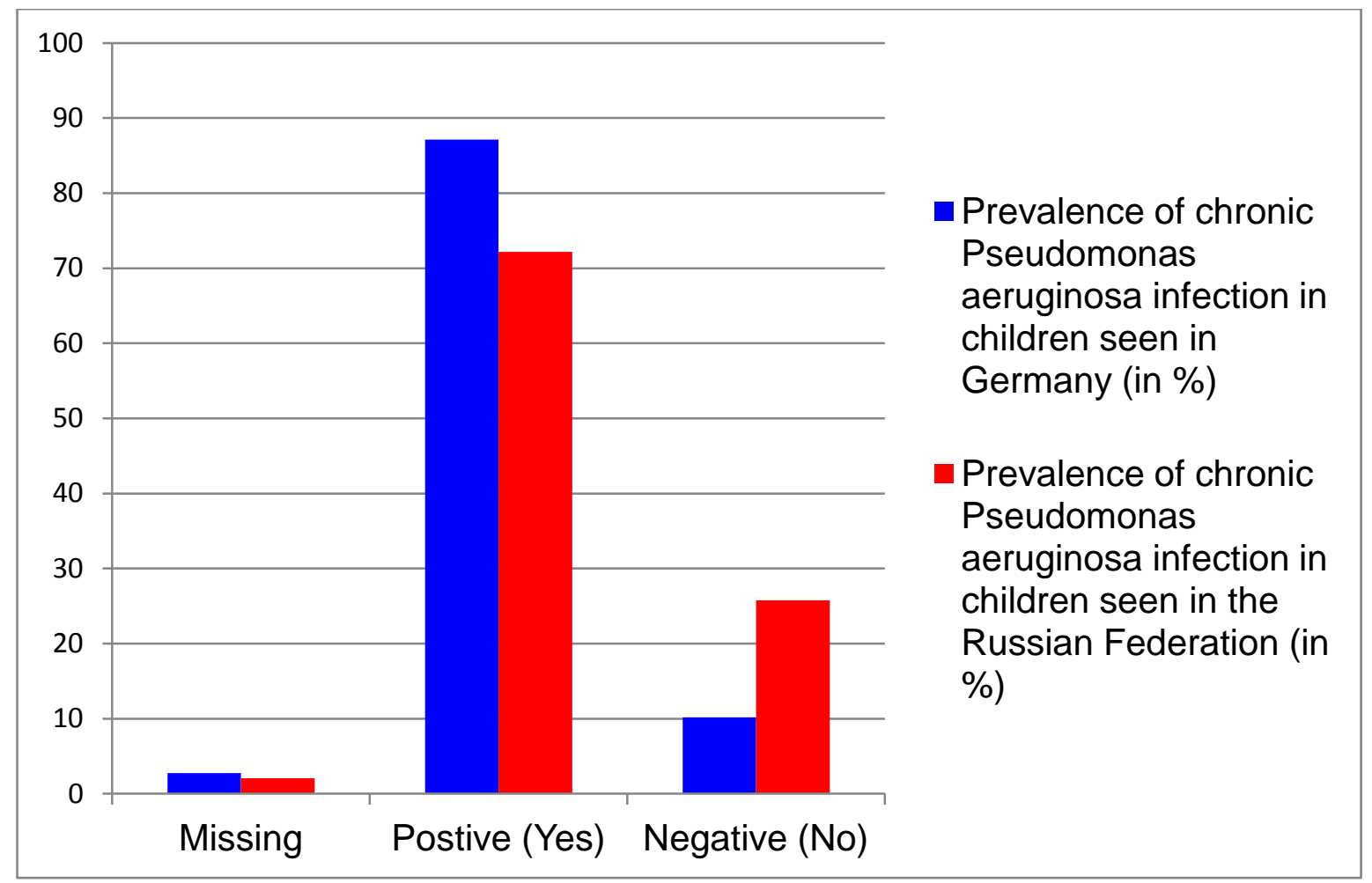

Fig. 10: Prevalence of chronic Pseudomonas aeruginosa infection observed in children in Germany and the Russian Federation (in \%).

According to ECFSPR annual report of $2017^{3}$, we could observe the prevalence of chronic $P$. aeruginosa infection in children (patients under 18 years old) in both countries is different. The rate of missing values is below 3 percent in both countries. The rate of presence of Pseudomonas aeruginosa in patients is above 80 percent in Germany (87.11\%) and below $75 \%$ in the Russian Federation (72.18\%). 


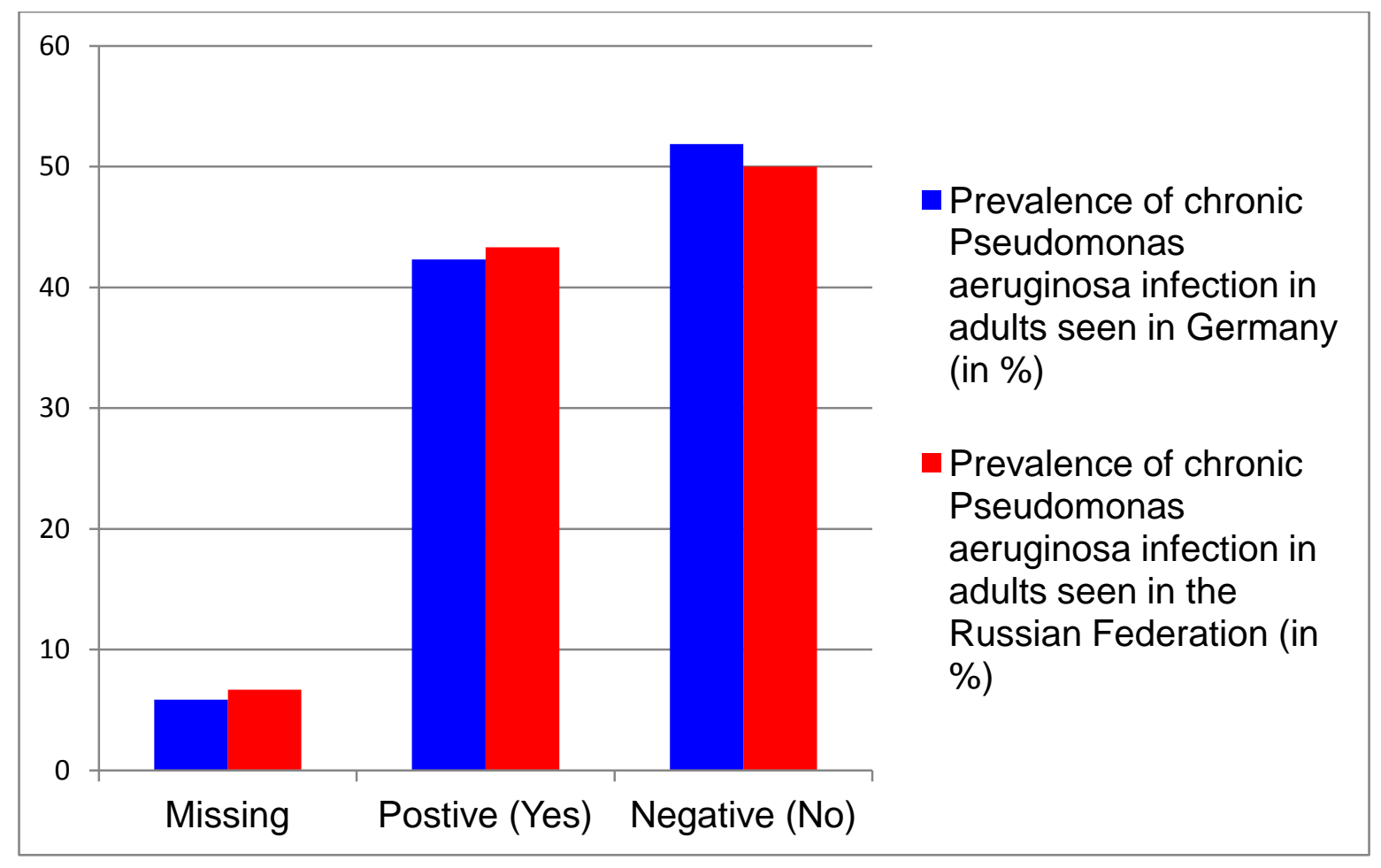

Fig. 11: Prevalence of chronic Pseudomonas aeruginosa infection observed in adults in Germany and the Russian Federation (in \%).

For patients older than 18 years,the ECFSPR annual report of 2017 shows a similar prevalence of chronic $P$. aeruginosa infection in both countries with a missing value rate below 7 percent. The rate of presence of $P$.aeruginosa in patients is below 50 percent in both countries, with $42.30 \%$ in Germany and with $43.32 \%$ in the Russian Federation.

In both countries, the highest rate of chronic $\mathrm{P}$. aeruginosa infection in CF patients is found in patients below the age of 18 . This could be related to an earlier time of death of patients infected with Pseudomonas aeruginosa and has to be proven in further studies. Nevertheless, Russian children with CF have proportionately less chronic P. aeruginosa infection than German children. German adults with CF, however, have a little less chronic P. aeruginosa infection than Russian adults. Due to age distribution effects (younger CF patient population in Russia ${ }^{3}$ ) Russian CF patients have a higher prevalence of chronic P. aeruginosa infections than German CF patients. 


\section{Comparison of the data of this study with data available in literature}

The data quality of our study should be discussed. First of all, it should be mentioned that data were not available from every patient every year. This is why the significance of the data should be nuanced. As an example, in 2015 for the entire cohort, only 486 out of 587 entries (82.79\%) were found for the BMI, only 440 out of $587(74.96 \%)$ entries were found for FEV1 and only 492 out of $587(83.82 \%)$ entries were found for intravenous antibiotic therapy. This shows that a significant amount of data is missing and that the quality of the data is negatively affected.

Moreover, the data was collected on one hand by doctors and clinic employees, which makes human bias in the data collection possible. On the other hand, this clinically collected data is entered manually into the computer system, which makes further errors possible and can explain missing data. Single entries in the clinic system were incomplete and not optimally documented. This was particularly the case for intravenous antibiotic therapy. The accuracy of the data, in particular for this parameter, can therefore be questioned.

Another problem is that the devices, with which the values for the BMI and the FEV1 were collected, was not documented. The balance systems used were neither described nor entered in the survey. Furthermore, it was not written down whether the FEV1 values were determined using spirometry or bodyplethysmography. Local experts said that it was mostly collected via spirometry. Unfortunately, this is not documented for every individual case. Calibration of devices is important for data precision. According to local experts, clinical rules and guidelines, this was the case for our study.

Deviations due to anomalies were also found in the patient's follow-up data. These have also affected the quality of the data and thus reduced the representativeness of the data.

In our study we could observe the Russian cohort is significantly younger than the

German cohort. Average ${ }^{108}$ age was 33.57 for Frankfurt, 25.59 for Moscow and for 
the total cohort 28.14. According to ECFSPR in 2017 mean average age was $22.4^{3}$ years in Germany and $12.4^{3}$ years in Russian Federation what confirms our results.

In Moscow 217 (50.70\%) male patients and 211 (49.30\%) female patients were counted, while in Frankfurt 92 (57.86\%) male patients and 67 (42.14\%) female patients were registered. According to ECFSPR in 2017 in Germany around 52\% were male patients and $48 \%$ were female. ${ }^{3}$ In Russian Federation the percentage was similar with about $51 \%$ male patients and $49 \%$ female patients ${ }^{3}$. These results were comparable with our study for Moscow. In Frankfurt the relative amount of male patients was higher than the German average. The observed gender gap could have influenced our results.

Because of the data problems described previously, BMI and FEV1 aren't statistically significant. We had to clean up the individual parameters from disruptive data and perform a cross-sectional analysis to obtain significant data. As a result of that we analyzed BMI between both centers for the year 2015. Moscow CF patients stratified by age groups had statistically significant lower BMI than Frankfurt CF patients in all age groups according to 3.4. (age 16-18: $p=0.003$; age 19-22: $p=0.004$; age 23-29: $p<0.001$; age 30-35: $p<0.001$; age 36-66: $p=0.024)^{108-111}$. According to ECFSPR in 2017 we found a smaller BMI gap with a BMI of 21.50 for Germany and a BMI of 21.10 for the Russian Federation ${ }^{3}$.

To analyze FEV1 values we had to match some parameters with influence on it, including height, age and sex category. This was the result of a lack of values not allowing us to use FEV1\%. Statistical analysis showed FEV1 was significantly lower for Moscow CF patients $(p<0.001)$ than for Frankfurt CF patients in 2015 for matched pairs by height (before matching $p=0.028$, after matching $p=0.876$ ), age (before matching $p<0.001$, after matching $p=0.484$ ) and sex category (before matching $p=0.088$, after matching $p=0.258$ ). According to ECFSPR annual report in 2017 German data seems to resemble the pooled data for all ECFS countries very 
closely $^{3}$, while the Russian data seem to be lower than pooled data and German data $^{3}$. This is in line with our FEV1 results in Frankfurt and Moscow.

Intravenous antibiotic therapies are usually done to treat pulmonary exacerbation (often due to chronic P. aeruginosa infection) in CF patients and frequency correlates with number of exacerbations. A clean-up of data didn't help to obtain satisfying significant values concerning the intravenous antibiotic therapies, because of inaccurate documentation and unsatisfactory data situation. Intravenous antibiotic therapies in Moscow were carried out more frequently than in Frankfurt in 2015, however, these differences were not statistically significant over a longer period of observation $(p>0,1)$. According to ECFSPR annual report of $2017^{3}$, we could observe the prevalence of chronic $P$. aeruginosa infection in both countries is quite similar. The rate of presence of $P$.aeruginosa in all patients is above 60 percent in both countries and seems to be a little higher in the Russian Federation (65.58\%), compared to Germany (61.06\%). This confirms our study results indicating higher exacerbation rates in Moscow. Due to age distribution effects (younger CF patient population in Russia ${ }^{3}$ ) Russian CF patients have a little bit higher prevalence of chronic P. aeruginosa infections than German CF patients.

\section{Possible explanation for the observed differences}

According to our expectations, BMI, FEV1 and chronic P. aeruginosa infections show a gap between both countries and this gap was shown partly by our both centers results too. Frankfurt is closer to normal values for BMI and FEV1 than Moscow. Only for the necessity of intravenous antibiotic therapy the gap wasn't statistically significant, what can possibly be explained by a lack of documentation in both centers and not always regular clinical examination. Patients are not forced to appear regularly and often just come when the CF exacerbation or the illness is high grade. The missing gap can also be explained by the different amount of testing in both countries. No exact data about P. aeruginosa testing has been published in both countries. The ECFSPR reports however around $3000 \mathrm{P}$. aeruginosa tests in 2017 in Russia ${ }^{3}$, meanwhile around 6000 P. aeruginosa tests in Germany ${ }^{3}$. 
Finally P. aeruginosa tests are realized twice as much in Germany than in Moscow. Fewer tests can contribute to a smaller number of detected P. aeruginosa cases (this phenomenon was also observed for the coronavirus pandemic in 2019$2020^{113,114}$ ). This could partially explain why the gap found in our study between Frankfurt and Moscow is not significant. Another point we have to take into consideration is the demographical difference between both countries. According to 3.6., we can see both countries have no relevant gap for BMI in the healthy population; however, we observed a significant BMI gap for all age categories in CF patients in 2015. To conclude, we can deduce the BMI gap for CF patients in Frankfurt and Moscow cannot be explained by demographical BMI differences.

According to the number of death patient totalized in our study, there were less deaths in Frankfurt than in Moscow. This can be partially explained by new therapies $^{115-117}$, a better organisation ${ }^{112,118}$ and a medicine that becomes more and more detailed and precise due to the economic possibilities and the research. This means that German patients are in a transition phase, where life expectancy increases. Patients in Russia yet are not in this phase. This may be linked to a possible delay in the use of more modern equipment and therapies, as well as probably lower or unevenly distributed financial means.

We think that quality of care as described above has a significant impact on prognosis in CF. Guidelines try to describe best clinical care. This is why we think it makes sense to look for the adherence to guidelines and especially look for differences in the management of these patients. The differences exposed in the table above in 3.7. may possibly partly explain the differences found for the surrogate parameters before. Guidelines are nevertheless simply indications how the clinical management has to be done and how the health care system has to work. Sometimes there may be deviations of the guidelines due to a lack of financial means, medical equipment, medical resources, to an individual therapy plan and other external factors. Therefore a bias of guidelines can arise. For instance an assessment of microbiological diagnostic procedures for respiratory specimens from CF 
patients in German laboratories shows most of laboratories follow guidelines. Some operating anomalies however were observed ${ }^{119}$.

Further studies have to be conducted to confirm the different guidelines take part in the gap of CF surrogate parameters and lifetime prognosis. Other causes have still to be considered and are discussed in the conclusions below.

First of all, the economic structures are different between both countries as well as the regional structures of Frankfurt and Moscow. Russia evaluated recently with the independence from the Soviet Union in 1991 and inherited an extensive centralized system ${ }^{120}$. In 1993 a mandatory health insurance (MHI) was introduced to open up an earmarked stream of funding for health care, but faced lots of fiscal constraints $^{120}$. The increase in energy prices on world markets brought welfare, macroeconomic stability, budget surplus and improvements in standards of living for the Russian population, however there is a split between urban and rural populations. Rural populations have worse health and poorer access to health services than urban populations ${ }^{120}$. Russian regions differ significantly in socio-economic, demographic and other parameters ${ }^{121}$. Different approaches to increase the capacity of these regions have to be developed by various type of management to ensure the availability and quality of health care for the population ${ }^{121}$. In Germany, the health system is build up in a different way. The state is organized federally and multiple adapted health care centers were created. This was also reflected in CF management. Since 1995, the German Cystic Fibrosis Quality Assessment project has collected demographic data and outcome parameters, what aims to develop tools for quality management and improve health care ${ }^{122}$. More than 90 CF centers $^{122}$ were created in Germany and CF data was collected in "muko.web" 97 . Annual reports are published ${ }^{97,123}$ and reveal an ever better coverage of the data year by year. Rapid development in diagnostic and therapeutic options have led to a significant increase in life expectancy ${ }^{118}$. New models of care were created for transition of structures, for instance to reduce the number of adult CF patients treated in pediatric CF institutions. In 2010 , around $40 \%$ of adult CF patients were treated in pediatric CF institutions ${ }^{118}$. This number was reduced in the past years 
and allowed a positive effect on the long-term course of the disease and the prognosis ${ }^{118}$. Different models were tested considering structural local conditions and offering a multidisciplinary treatment approach. Further improvements in the system of cystic fibrosis care are required, exemplarily involvement of patients and their families in quality management ${ }^{122}$. Finally both countries and both centers have different health care and organization strategies due to various parameters and history inheritance. This could also partly explain our results, but has to be confirmed in further studies, where economical, management and organization can be monitored.

\section{Conclusions}

Data described both CF-populations in Frankfurt and Moscow. At first glance values of BMI, FEV1 and the necessity of intravenous antibiotic therapy were closer to normal in Frankfurt than in Moscow. An evaluation of both CF-populations for 2015 revealed BMI was significantly higher in Frankfurt, than in Moscow. A high BMI is a positive predictor for a better outcome ${ }^{124,125}$ and decreased mortality ${ }^{124}$. Epidemiological analysis of normal German ${ }^{104}$ and Russian ${ }^{105-107}$ population didn't explain this severe gap (referred to 3.6.). In the same way both FEV1 populations of 2015 obtained with the R-program to get comparable samples showed Frankfurt CFpatients have a closer to normal FEV1 than Moscow CF-patients. A better FEV1 is associated with a better outcome ${ }^{124}$ and a lower mortality. Subsequently these data indicate Frankfurt patients should have a better outcome than Moscow patients.

Our results have to be interpreted with caution, because our data range is very small and incomplete for the years before 2015 and in particular before 2010. To better describe the differences between both CF-centers and both CF-populations a study with a broader perspective should be started to verify if this gap is maintained over a longer period of time (three to five years). The evaluation of the necessity of intravenous antibiotic treatment has also to be examined and the observed better values for Frankfurt have to be proved statistically. The relation between the necessity of intravenous antibiotic therapy and a worse outcome for CF- 
patients has to be discussed. A study published in 2015 questioned the link between both and put other antibiotic treatments (oral therapy or inhaled therapy) on the same acting level ${ }^{126}$. Subsequently, other antibiotic therapies have to be considered and data should be collected about them. Another broader study should examine mortality in both centers to prove the impact of the surrogate markers, which has been described ${ }^{43}$.

Furthermore, the reasons of these gaps in surrogate markers for CF prognosis have to be investigated. One possible cause could be a possible difference in F508del mutation or other CF-specific gene mutation distribution ${ }^{1}$. These data should be collected in a further study. Moreover, epidemiologic reasons should be regarded in a larger scale and also compared and evaluated in another study. Socioeconomic differences between both countries should also be considered and could be explanations for gaps between both CF-patient populations. Nevertheless they should be nuanced by a comparison with socioeconomic status of normal populations. In particular, different types of drugs, modes of application, frequency of application, treatment regimens and the availability of medication could play a role. Other reasons that must be considered in further studies are the different therapeutic approaches and the differences in care in both countries.

In summary, we have identified that Frankfurt CF patients values for surrogate parameters of CF outcome were closer to normal than those in Moscow patients in a short time. Further studies should verify this difference on a longer lapse of time including larger data spectrum. First, this will allow to establish a hypothesis explaining this difference. Secondly, this could help to refine therapeutic approaches and to definite new recommendations. 


\section{Appendix}

A)

\begin{tabular}{|c|c|c|c|c|c|c|}
\hline Examination & Number of & Patients & Average & $3 \mathrm{Ml}$ & Median B & \\
\hline Year & Frankfurt & Moscow & Frankfurt & Moscow & Frankfurt & Moscow \\
\hline 1990 & 2 & 0 & 21.52 & - & 21.52 & - \\
\hline 1991 & 2 & 1 & 21.54 & 14.49 & 21.54 & 14.49 \\
\hline 1992 & 1 & 2 & 21.50 & 16.27 & 21.50 & 16.27 \\
\hline 1993 & 2 & 7 & 20.91 & 16.44 & 20.91 & 15.08 \\
\hline 1994 & 1 & 11 & 20.02 & 17.34 & 20.02 & 17.16 \\
\hline 1995 & 10 & 7 & 16.66 & 17.36 & 16.11 & 17.16 \\
\hline 1996 & 30 & 10 & 18.84 & 16.91 & 18.52 & 17.39 \\
\hline 1997 & 35 & 23 & 19.41 & 17.61 & 19.55 & 17.72 \\
\hline 1998 & 46 & 38 & 19.89 & 16.34 & 19.66 & 16.45 \\
\hline 1999 & 45 & 39 & 19.97 & 17.33 & 19.13 & 17.65 \\
\hline 2000 & 30 & 45 & 20.29 & 16.98 & 19.09 & 16.53 \\
\hline 2001 & 14 & 53 & 19.07 & 16.79 & 18.05 & 16.85 \\
\hline 2002 & 16 & 64 & 18.78 & 17.41 & 18.02 & 17.54 \\
\hline 2003 & 68 & 78 & 21.43 & 17.42 & 20.85 & 17.55 \\
\hline 2004 & 75 & 103 & 21.48 & 17.49 & 20.76 & 17.57 \\
\hline 2005 & 13 & 101 & 20.57 & 18.04 & 20.68 & 18.03 \\
\hline 2006 & 13 & 124 & 20.95 & 18.02 & 21.27 & 17.96 \\
\hline 2007 & 13 & 160 & 20.51 & 18.11 & 21.10 & 18.13 \\
\hline 2008 & 91 & 179 & 21.69 & 18.38 & 21.01 & 18.55 \\
\hline 2009 & 84 & 188 & 22.39 & 18.55 & 21.81 & 18.52 \\
\hline 2010 & 132 & 192 & 21.20 & 18.76 & 20.70 & 18.69 \\
\hline 2011 & 137 & 199 & 21.40 & 18.71 & 21.14 & 18.47 \\
\hline 2012 & 131 & 250 & 21.80 & 18.79 & 21.62 & 18.51 \\
\hline 2013 & 130 & 263 & 21.99 & 18.68 & 21.66 & 18.29 \\
\hline 2014 & 133 & 278 & 22.12 & 18.78 & 21.73 & 18.52 \\
\hline
\end{tabular}




\begin{tabular}{|c|c|c|c|c|c|c|}
\hline 2015 & 141 & 301 & 22.24 & 18.74 & 21.63 & 18.59 \\
\hline \multirow[t]{2}{*}{ Year } & \multicolumn{2}{|c|}{$\begin{array}{l}\text { BMI standard } \\
\text { deviation (SD) }\end{array}$} & \multicolumn{2}{|c|}{ BMI maximum } & \multicolumn{2}{|c|}{ BMI minimum } \\
\hline & Frankfurt & Moscow & Frankfurt & Moscow & Frankfurt & Moscow \\
\hline 1990 & 0.64 & - & 21.98 & - & 21.07 & - \\
\hline 1991 & 1.13 & - & 22.34 & 14.49 & 20.75 & 14.49 \\
\hline 1992 & - & 1.75 & 21.50 & 17.51 & 21.50 & 15.03 \\
\hline 1993 & 1.26 & 2.88 & 21.80 & 20.93 & 20.02 & 13.22 \\
\hline 1994 & - & 3.82 & 20.02 & 25.00 & 20.02 & 13.34 \\
\hline 1995 & 2.29 & 2.37 & 20.64 & 22.21 & 13.68 & 15.43 \\
\hline 1996 & 3.17 & 2.21 & 25.83 & 19.37 & 14.07 & 13.47 \\
\hline 1997 & 3.18 & 2.49 & 28.22 & 22.77 & 13.71 & 13.34 \\
\hline 1998 & 3.18 & 3.58 & 27.64 & 22.77 & 13.65 & 1.92 \\
\hline 1999 & 3.52 & 2.51 & 31.11 & 22.94 & 14.88 & 12.63 \\
\hline 2000 & 4.89 & 2.71 & 37.56 & 24.15 & 13.13 & 12.70 \\
\hline 2001 & 4.02 & 2.69 & 27.76 & 22.76 & 14.60 & 12.40 \\
\hline 2002 & 2.94 & 2.65 & 24.01 & 23.23 & 14.74 & 11.65 \\
\hline 2003 & 3.76 & 2.70 & 33.30 & 23.61 & 13.98 & 11.65 \\
\hline 2004 & 4.05 & 2.77 & 35.50 & 24.88 & 12.93 & 10.82 \\
\hline 2005 & 3.22 & 2.76 & 26.35 & 25.86 & 13.73 & 12.02 \\
\hline 2006 & 3.35 & 2.83 & 26.67 & 25.72 & 14.38 & 12.03 \\
\hline 2007 & 3.58 & 2.73 & 24.97 & 25.62 & 13.89 & 12.73 \\
\hline 2008 & 4.10 & 2.79 & 40.75 & 26.23 & 14.38 & 11.83 \\
\hline 2009 & 4.41 & 2.78 & 44.29 & 26.03 & 15.34 & 12.80 \\
\hline 2010 & 4.20 & 2.84 & 45.35 & 30.03 & 14.27 & 12.60 \\
\hline 2011 & 4.18 & 2.90 & 45.52 & 31.99 & 14.35 & 12.47 \\
\hline 2012 & 4.03 & 2.69 & 45.34 & 27.73 & 13.86 & 12.47 \\
\hline 2013 & 4.04 & 2.80 & 44.47 & 27.73 & 13.86 & 10.85 \\
\hline 2014 & 4.17 & 2.86 & 45.41 & 31.46 & 14.10 & 13.02 \\
\hline 2015 & 4.13 & 2.78 & 46.60 & 31.46 & 14.17 & 11.33 \\
\hline
\end{tabular}




\begin{tabular}{|c|c|c|c|c|c|c|}
\hline \multirow[t]{2}{*}{ Year } & \multicolumn{2}{|l|}{ BMI range } & \multicolumn{2}{|c|}{ BMI 1st quartile } & \multicolumn{2}{|c|}{ BMI 3rd quartile } \\
\hline & Frankfurt & Moscow & Frankfurt & Moscow & Frankfurt & Moscow \\
\hline 1990 & 0.91 & - & - & - & - & - \\
\hline 1991 & 1.59 & 0.00 & - & - & - & - \\
\hline 1992 & 0.00 & 2.48 & - & - & - & - \\
\hline 1993 & 1.78 & 7.71 & - & 14.49 & - & 18.42 \\
\hline 1994 & 0.00 & 11.66 & - & 14.22 & - & 19.30 \\
\hline 1995 & 6.96 & 6.78 & 15.21 & 15.64 & 17.29 & 17.70 \\
\hline 1996 & 11.76 & 5.90 & 16.51 & 15.35 & 20.88 & 18.85 \\
\hline 1997 & 14.51 & 9.43 & 17.38 & 15.89 & 20.87 & 19.12 \\
\hline 1998 & 13.99 & 20.85 & 17.93 & 14.22 & 21.60 & 18.46 \\
\hline 1999 & 16.23 & 10.32 & 17.79 & 15.41 & 21.72 & 19.00 \\
\hline 2000 & 24.43 & 11.45 & 17.59 & 14.81 & 21.15 & 19.23 \\
\hline 2001 & 13.16 & 10.36 & 15.90 & 14.66 & 21.14 & 18.67 \\
\hline 2002 & 9.27 & 11.58 & 16.76 & 15.23 & 21.38 & 18.93 \\
\hline 2003 & 19.33 & 11.96 & 19.03 & 15.23 & 22.92 & 19.11 \\
\hline 2004 & 22.57 & 14.06 & 19.23 & 15.21 & 23.00 & 19.47 \\
\hline 2005 & 12.61 & 13.85 & 19.33 & 16.37 & 22.01 & 19.68 \\
\hline 2006 & 12.29 & 13.69 & 19.76 & 15.66 & 22.60 & 19.82 \\
\hline 2007 & 11.08 & 12.89 & 20.48 & 16.28 & 22.92 & 19.91 \\
\hline 2008 & 26.37 & 14.40 & 19.58 & 16.47 & 22.80 & 20.09 \\
\hline 2009 & 28.95 & 13.22 & 20.03 & 16.71 & 23.46 & 19.93 \\
\hline 2010 & 31.08 & 17.43 & 18.81 & 16.97 & 22.95 & 20.20 \\
\hline 2011 & 31.17 & 19.53 & 19.05 & 16.93 & 23.13 & 20.45 \\
\hline 2012 & 31.48 & 15.27 & 19.34 & 16.86 & 23.29 & 20.45 \\
\hline 2013 & 30.61 & 16.88 & 19.58 & 16.82 & 23.69 & 20.43 \\
\hline 2014 & 31.32 & 18.44 & 19.31 & 16.86 & 23.81 & 20.50 \\
\hline 2015 & 32.43 & 20.13 & 19.31 & 16.82 & 24.14 & 20.32 \\
\hline
\end{tabular}


B)

\begin{tabular}{|c|c|c|c|c|c|c|}
\hline \multirow[t]{2}{*}{ Year } & \multicolumn{4}{|c|}{ Number of } & \multicolumn{2}{|c|}{ FEV1 median } \\
\hline & Frankfurt & Moscow & Frankfurt & Moscow & Frankfurt & Moscow \\
\hline 1990 & 2 & 0 & 3800 & - & 3800 & - \\
\hline 1991 & 2 & 0 & 3590 & - & 3590 & - \\
\hline 1992 & 1 & 1 & 4370 & 2820 & 4370 & 2820 \\
\hline 1993 & 2 & 4 & 3600 & 1280 & 3600 & 1000 \\
\hline 1994 & 1 & 8 & 2550 & 1706.25 & 2550 & 1210 \\
\hline 1995 & 6 & 6 & 2136.67 & 1216.67 & 2030 & 1155 \\
\hline 1996 & 27 & 6 & 1825.93 & 1783.33 & 1800 & 1685 \\
\hline 1997 & 34 & 19 & 2150.88 & 1998.42 & 2070 & 1640 \\
\hline 1998 & 42 & 24 & 2357.62 & 1783.33 & 2090 & 1350 \\
\hline 1999 & 44 & 28 & 2244.32 & 2215.00 & 2205 & 1980 \\
\hline 2000 & 28 & 25 & 2512.86 & 2193.20 & 2555 & 2300 \\
\hline 2001 & 13 & 30 & 2333.85 & 2019.67 & 2120 & 1955 \\
\hline 2002 & 17 & 37 & 2328.82 & 2026.76 & 2090 & 1920 \\
\hline 2003 & 66 & 50 & 2439.39 & 2186.00 & 2320 & 2000 \\
\hline 2004 & 71 & 67 & 2447.89 & 2221.34 & 2340 & 2020 \\
\hline 2005 & 15 & 73 & 2366.67 & 2296.71 & 2350 & 2030 \\
\hline 2006 & 13 & 87 & 2571.54 & 2202.41 & 2450 & 2040 \\
\hline 2007 & 13 & 125 & 2728.46 & 2301.36 & 2480 & 2130 \\
\hline 2008 & 93 & 155 & 2354.73 & 2247.81 & 2230 & 2010 \\
\hline 2009 & 86 & 171 & 2488.72 & 2299.30 & 2450 & 2220 \\
\hline 2010 & 133 & 169 & 2463.91 & 2270.77 & 2270 & 2120 \\
\hline 2011 & 137 & 176 & 2446.93 & 2192.33 & 2300 & 2090 \\
\hline 2012 & 133 & 234 & 2437.44 & 2136.54 & 2230 & 2030 \\
\hline 2013 & 135 & 251 & 2450.67 & 2120.84 & 2370 & 2020 \\
\hline 2014 & 135 & 275 & 2426.81 & 2057.35 & 2310 & 1900 \\
\hline 2015 & 145 & 295 & 2460.34 & 1983.12 & 2290 & 1850 \\
\hline
\end{tabular}




\begin{tabular}{|lllllll|}
\hline \multicolumn{5}{l}{ Fear } & \multicolumn{4}{l}{ FEV1 standard } & & & \\
& deviation (SD) & FEV1 maximum & \multicolumn{2}{l|}{ FEV1 minimum } \\
& Frankfurt & Moscow & Frankfurt & Moscow & Frankfurt & Moscow \\
\hline 1990 & 565.69 & - & 4200 & - & 3400 & - \\
1991 & 1343.50 & - & 4540 & - & 2640 & - \\
1992 & - & - & 4370 & 2820 & 4370 & 2820 \\
1993 & 1173.80 & 671.71 & 4430 & 2280 & 2770 & 840 \\
1994 & - & 1290.10 & 2550 & 4390 & 2550 & 610 \\
1995 & 638.55 & 647.79 & 3320 & 2420 & 1520 & 600 \\
1996 & 512.72 & 1070.49 & 3090 & 3180 & 920 & 630 \\
1997 & 726.81 & 1160.03 & 3960 & 4060 & 870 & 610 \\
1998 & 883.31 & 1036.85 & 4400 & 3820 & 1090 & 570 \\
1999 & 821.57 & 1126.85 & 4310 & 5020 & 130 & 580 \\
2000 & 906.30 & 948.37 & 4080 & 3810 & 900 & 870 \\
2001 & 1041.78 & 1000.76 & 4330 & 4330 & 560 & 570 \\
2002 & 1053.90 & 905.15 & 4540 & 4060 & 600 & 660 \\
2003 & 1027.37 & 1044.13 & 5820 & 4510 & 500 & 600 \\
2004 & 908.67 & 1063.67 & 4870 & 4790 & 570 & 480 \\
2005 & 1074.40 & 1141.05 & 4530 & 6490 & 920 & 460 \\
2006 & 930.45 & 1036.96 & 4530 & 5980 & 960 & 610 \\
2007 & 1053.31 & 1043.37 & 4590 & 5650 & 1340 & 510 \\
2008 & 971.57 & 1114.60 & 5030 & 5870 & 580 & 380 \\
2009 & 1055.56 & 1073.32 & 5440 & 6240 & 560 & 480 \\
2010 & 1036.99 & 981.22 & 5390 & 5390 & 710 & 730 \\
2011 & 1028.96 & 1036.40 & 5440 & 5080 & 650 & 420 \\
2012 & 1023.65 & 1036.54 & 5130 & 6420 & 580 & 450 \\
2013 & 1015.53 & 1034.53 & 5300 & 6400 & 690 & 500 \\
2014 & 1042.62 & 990.51 & 5370 & 5130 & 730 & 192 \\
2015 & 1112.38 & 985.01 & 5410 & 5220 & 600 & 520 \\
\hline
\end{tabular}




\begin{tabular}{|c|c|c|c|c|c|c|}
\hline \multirow[t]{2}{*}{ Year } & \multicolumn{2}{|c|}{ FEV1 range } & \multicolumn{2}{|c|}{ FEV1 1st quartile } & \multicolumn{2}{|c|}{ FEV1 3rd quartile } \\
\hline & Frankfurt & Moscow & Frankfurt & Moscow & Frankfurt & Moscow \\
\hline 1990 & 800 & - & - & - & - & - \\
\hline 1991 & 1900 & - & - & - & - & - \\
\hline 1992 & 0 & 0 & - & 2820 & - & 2820 \\
\hline 1993 & 1660 & 1440 & - & 930 & - & 1350 \\
\hline 1994 & 0 & 3780 & - & 870 & - & 1972.5 \\
\hline 1995 & 1800 & 1820 & 1755 & 807.5 & 2200 & 1247.5 \\
\hline 1996 & 2170 & 2550 & 1515 & 892.5 & 2060 & 2590 \\
\hline 1997 & 3090 & 3450 & 1720 & 1090 & 2517.5 & 2975 \\
\hline 1998 & 3310 & 3250 & 1772.5 & 975 & 2897.5 & 2472.5 \\
\hline 1999 & 4180 & 4440 & 1775 & 1357.5 & 2607.5 & 3085 \\
\hline 2000 & 3180 & 2940 & 1760 & 1230 & 3402.5 & 2740 \\
\hline 2001 & 3770 & 3760 & 1520 & 1135 & 3000 & 2655 \\
\hline 2002 & 3940 & 3400 & 1600 & 1280 & 3090 & 2540 \\
\hline 2003 & 5320 & 3910 & 1755 & 1262.5 & 3157.5 & 2807.5 \\
\hline 2004 & 4300 & 4310 & 1805 & 1405 & 2915 & 2865 \\
\hline 2005 & 3610 & 6030 & 1805 & 1540 & 2790 & 2710 \\
\hline 2006 & 3570 & 5370 & 2030 & 1500 & 2870 & 2695 \\
\hline 2007 & 3250 & 5140 & 1920 & 1680 & 3440 & 2840 \\
\hline 2008 & 4450 & 5490 & 1670 & 1370 & 2940 & 2985 \\
\hline 2009 & 4880 & 5760 & 1732.5 & 1455 & 2980 & 3045 \\
\hline 2010 & 4680 & 4660 & 1690 & 1560 & 2980 & 2970 \\
\hline 2011 & 4790 & 4660 & 1680 & 1355 & 2960 & 2890 \\
\hline 2012 & 4550 & 5970 & 1670 & 1332.5 & 3060 & 2820 \\
\hline 2013 & 4610 & 5900 & 1690 & 1315 & 2975 & 2730 \\
\hline 2014 & 4640 & 4938 & 1690 & 1230 & 2895 & 2785 \\
\hline 2015 & 4810 & 4700 & 1600 & 1245 & 3280 & 2585 \\
\hline
\end{tabular}


C)

\begin{tabular}{|c|c|c|c|c|}
\hline \multirow[t]{2}{*}{ Year } & \multicolumn{2}{|c|}{ Number of Patient data } & \multicolumn{2}{|c|}{$\begin{array}{l}\text { Necessity of intravenous antibiotic } \\
\text { therapy }\end{array}$} \\
\hline & Frankfurt & Moscow & Frankfurt & Moscow \\
\hline 1990 & 24 & 1 & 1 & 0 \\
\hline 1991 & 24 & 2 & 1 & 0 \\
\hline 1992 & 25 & 3 & 1 & 1 \\
\hline 1993 & 26 & 9 & 1 & 2 \\
\hline 1994 & 26 & 15 & 1 & 3 \\
\hline 1995 & 27 & 12 & 3 & 4 \\
\hline 1996 & 27 & 15 & 2 & 4 \\
\hline 1997 & 27 & 26 & 2 & 8 \\
\hline 1998 & 30 & 43 & 6 & 15 \\
\hline 1999 & 31 & 44 & 6 & 18 \\
\hline 2000 & 33 & 54 & 7 & 20 \\
\hline 2001 & 36 & 61 & 10 & 19 \\
\hline 2002 & 41 & 83 & 21 & 26 \\
\hline 2003 & 48 & 90 & 25 & 31 \\
\hline 2004 & 58 & 111 & 32 & 44 \\
\hline 2005 & 63 & 118 & 27 & 46 \\
\hline 2006 & 66 & 147 & 24 & 64 \\
\hline 2007 & 69 & 180 & 32 & 79 \\
\hline 2008 & 90 & 209 & 43 & 99 \\
\hline 2009 & 98 & 201 & 35 & 97 \\
\hline 2010 & 118 & 209 & 47 & 100 \\
\hline 2011 & 130 & 222 & 49 & 105 \\
\hline 2012 & 130 & 256 & 48 & 130 \\
\hline 2013 & 139 & 270 & 52 & 143 \\
\hline 2014 & 142 & 274 & 57 & 167 \\
\hline 2015 & 148 & 295 & 58 & 191 \\
\hline
\end{tabular}




\begin{tabular}{|lll|}
\hline Year & Percentage of necessity of intravenous antibiotic therapy \\
& Frankfurt & Moscow \\
\hline 1990 & 4.17 & 0.00 \\
1991 & 4.17 & 0.00 \\
1992 & 4.00 & 33.33 \\
1993 & 3.85 & 22.22 \\
1994 & 3.85 & 20.00 \\
1995 & 11.11 & 33.33 \\
1996 & 7.41 & 26.67 \\
1997 & 7.41 & 30.77 \\
1998 & 20.00 & 34.88 \\
1999 & 19.35 & 40.91 \\
2000 & 21.21 & 37.04 \\
2001 & 27.78 & 31.15 \\
2002 & 51.22 & 31.33 \\
2003 & 52.08 & 34.44 \\
2004 & 55.17 & 39.64 \\
2005 & 42.86 & 38.98 \\
2006 & 36.36 & 43.54 \\
2007 & 46.38 & 43.89 \\
2008 & 47.78 & 47.37 \\
2009 & 35.71 & 48.26 \\
2010 & 39.83 & 47.85 \\
2011 & 37.69 & 47.30 \\
2012 & 36.92 & 50.78 \\
2013 & 37.41 & 52.96 \\
2014 & 40.14 & 60.95 \\
2015 & 39.19 & 64.75 \\
\hline
\end{tabular}


Table 10: A) BMI biometrical descriptive statistics from 1990 to 2015 including number of patient data sets, average BMI, median BMI, SD (standard deviation) $B M I$, maximum $B M I$, minimum $B M I, B M I$ range, $1^{\text {st }}$ quartile $B M I$ and $3^{\text {rd }}$ quartile BMI.

B) FEV1 biometrical descriptive statistic from 1990 to 2015 including number of patient data, average FEV1, median FEV1, SD (standard deviation) FEV1, maximum FEV1, minimum FEV1, FEV1 range, $1^{\text {st }}$ quartile FEV1 and $3^{\text {rd }}$ quartile FEV1.

C) Biometrical descriptive statistic analysis of necessity of intravenous antibiotic therapy from 1990 to 2015 including number of patient data, number of necessity of intravenous antibiotic therapy and percentage of necessity of intravenous antibiotic therapy.

\section{Conflict of interest statement}

The authors have declared that no conflict of interest exists.

\section{Declarations of interest}

None. 


\section{Summary}

\section{Background}

Previous studies have demonstrated that CF prognosis is dependent of three major parameters: FEV1, BMI and need of intravenous antibiotic therapy. The CF centres of Frankfurt, Germany, and Moscow, Russia, care for cystic fibrosis patients from childhood through adult age. We decided to investigate and compare both centers for the three most important CF prognostic parameters (BMI, FEV1, need of intravenous antibiotics) from 1990 to 2015. Differences in these three parameters have an influence on CF lifetime prognosis and have to be examined. No comparable study has been published so far.

\section{Methods}

German patient data was collected from the national cystic fibrosis database "Muko.web". Missing values were extracted from the Hospital Information System (Orbis serving as the medical record data bank of the University Hospital in Frankfurt). Russian patient data were taken directly from the medical records in Moscow and, after they had been anonymized, they were handed over and merged in a table with the German patient data. In a descriptive statistical analysis with Bias and $\mathrm{R}$ Studio the values were compared.

\section{Results}

428 patients from Moscow (217 male, 211 female; 348 (81,3\%) were P. aeruginosa positive) and 159 patients from Frankfurt (92 male, 67 female; 137 (86,2\%) with P. aeruginosa positive) were compared with regard to P. aeruginosa positivity, BMI, FEV1 and need of intravenous antibiotic therapy. A difference was observed in both prognostic parameters FEV1 and BMI for 2015; CF patients in Moscow stratified by age groups had lower BMI than CF patients in Frankfurt (age 16-18: $p=0,003$; age 19-22: $p=0,004$; age 23-29: $p<0,001$; age 30-35: $p<0,001$; age 36-66: $\mathrm{p}=0,024)$. In a matching pairs analysis including 100 patients from Frankfurt and 
100 patients from Moscow for the year 2015 FEV1 was significantly lower in Moscow patients $(p<0,001)$.

\section{Conclusions}

This study showed a significant difference in prognostic parameters between Frankfurt and Moscow in the cross-sectional analysis for the year 2015. A further study should evaluate this difference to show whether this difference will be found over a longer period of time and how relevant it is. The reason for this prognostic gap between patients in Moscow and Frankfurt could be epidemiological, socioeconomic, based on a difference in genetics (F508del mutation prevalence), but could as well be based on a difference in care or on different therapeutic approaches and should be investigated in a broader study. After this study modifications in treatment plans, medical investments or/and therapeutic approaches can be modified to influence positively the lifetime prognosis of patients in centers with a worse outcome. 


\section{Zusammenfassung}

\section{Hintergrund}

Frühere Studien haben gezeigt, dass die Prognose von CF-Patienten von drei $\mathrm{Pa}$ rametern abhängt. Es handelt sich hierbei um die FEV1, den BMI und die Notwendigkeit einer intravenösen Antibiotikatherapie. Die CF-Zentren in Frankfurt (Deutschland) und Moskau (Russland) betreuen Mukoviszidose-Patienten vom Lebensbeginn an bis hin zum Lebensende. Wir haben uns entschlossen in beide Zentren die drei wichtigsten prognostischen CF-Parameter (BMI, FEV1, Notwendigkeit einer intravenösen Antibiotikatherapie) von 1990 bis 2015 zu erheben und zu vergleichen. Unterschiede in diesen drei Parametern haben einen starken Einfluss auf die Lebenszeitprognose der CF-Patienten und müssen untersucht werden. Bisher wurde keine vergleichbare Studie durchgeführt und veröffentlicht.

\section{Methoden}

Deutsche Patientendaten wurden aus der nationalen Mukoviszidose-Datenbank „Muko.web" erhoben. Fehlende Werte wurden aus dem Krankenhausinformationssystem (Orbis als Datenbank des Universitätsklinikums Frankfurt) extrahiert. Russische Patientendaten wurden direkt aus den Krankenakten in Moskau entnommen und nach ihrer Anonymisierung übermittelt. Schließlich wurden die Daten aus beiden Zentren in einer Tabelle zusammengeführt. In einer deskriptiven statistischen Analyse mit Bias und R Studio wurden die Werte anschließend verglichen.

\section{Ergebnisse}

428 Patienten aus Moskau (217 Männer, 211 Frauen; 348 (81,3\%) waren P. aeruginosa-positiv) und 159 Patienten aus Frankfurt (92 Männer, 67 Frauen; 137 $(86,2 \%)$ mit P. aeruginosa-positiv) wurden in Hinsicht auf der P. aeruginosa Präsenz, dem BMI, der FEV1 und der Notwendigkeit einer intravenösen Antibiotikatherapie verglichen. Ein Unterschied wurde sowohl bei den prognostischen Parametern FEV1 als auch beim BMI für 2015 beobachtet. Nach Altersgruppen geschichtete CF-Patienten in Moskau hatten einen niedrigeren BMI als CF-Patienten in 
Frankfurt (Alter 16-18: $p=0,003$; Alter 19-22: $p=0,004$; Alter 23-29: $p<0,001$; Alter 30-35: $p<0,001$; Alter 36-66: $p=0,024)$. In einer Matching-Pair-Analyse mit 100 Patienten aus Frankfurt und 100 Patienten aus Moskau für das Jahr 2015 war die FEV1 bei Moskauer Patienten signifikant niedriger $(p<0,001)$.

\section{Schlussfolgerungen}

Diese Studie zeigte einen signifikanten Unterschied in den prognostischen Parametern zwischen Frankfurt und Moskau für das Jahr 2015 in einer Querschnittsanalyse. Eine weitere Studie sollte diesen Unterschied über einen längeren Zeitraum nachweisen, damit festgestellt werden kann inwiefern dieser Unterschied relevant ist. Die Ursache dieser Unterschiede könnte auf einen oder mehrere Faktoren beruhen. Diskutiert werden epidemiologische, sozioökonomische (finanzielle Mittel, sowie Verteilung der Pflegeeinrichtungen und der Pflegemittel), genetische (F508del-Mutationsverteilung), pflegerische, therapeutische und medikamentöse Ansätze, die wiederum in einer weiteren Studie untersucht werden sollten. Abhängig von den Ergebnissen dieser Studie könnten Veränderungen in den Behandlungsplänen, in der Umverteilung medizinischer Investitionen und/oder in den therapeutischen Ansätzen erfolgen, um die Lebenszeitprognose von CFPatienten in Zentren mit schlechteren Prognoseparametern positiv zu beeinflussen. 


\section{References}

1. Meng X, Clews J, Ciuta AD, Martin ER, Ford RC. CFTR structure, stability, function and regulation. Biol Chem. 2019. doi:10.1515/hsz-2018-0470.

2. Dr. Volker Melichar, PD Dr. Michael Hogardt. Mukoviszidose - Ursache, Krankheitsbild und Therapie. [Informationen für Patienten, Angehörige und Interessierte]. 2018:1-32.

3. European Cystic Fibrosis Society. ECFS Patient Registry - Annual Data Report 2017. 2017.

4. Matthys $\mathrm{H}$, Seeger W. Klinische Pneumologie. 4., überarbeitete und aktualisierte Auflage. Berlin, Heidelberg: Springer Berlin Heidelberg; 2008. http://dx.doi.org/10.1007/978-3-540-37692-7.

5. Cystic Fibrosis Mutation Database. [CFMDB Statistics]. http://www.genet.sickkids.on.ca/cftr/StatisticsPage.html.

6. US CF Foundation, Johns Hopkins University, The Hospital for Sick Children. The Clinical and Functional Translation of CFTR (CFTR2) - Helpful information about CF and CFTR2. http://cftr2.org/resources.

7. Kerem E, Corey M, Kerem BS, et al. The relation between genotype and phenotype in cystic fibrosis--analysis of the most common mutation (delta F508). N Engl J Med. 1990;323(22):1517-1522. doi:10.1056/NEJM199011293232203.

8. Veit G, Avramescu RG, Chiang AN, et al. From CFTR biology toward combinatorial pharmacotherapy: expanded classification of cystic fibrosis mutations. $\mathrm{Mol}$ Biol Cell. 2016;27(3):424-433. doi:10.1091/mbc.E14-04-0935.

9. Tsui LC, Durie P. Genotype and phenotype in cystic fibrosis. Hosp Pract (1995). 1997;32(6):115-8, 123-9, 134, passim. doi:10.1080/21548331.1997.11443512.

10.Ward CL, Kopito RR. Intracellular turnover of cystic fibrosis transmembrane conductance regulator. Inefficient processing and rapid degradation of wild-type and mutant proteins. J Biol Chem. 1994;269(41):25710-25718. 
11.Anderson MP, Welsh MJ. Regulation by ATP and ADP of CFTR chloride channels that contain mutant nucleotide-binding domains. Science. 1992;257(5077):1701-1704. doi:10.1126/science.1382316.

12.Sheppard DN, Rich DP, Ostedgaard LS, Gregory RJ, Smith AE, Welsh MJ. Mutations in CFTR associated with mild-disease-form Cl- channels with altered pore properties. Nature. 1993;362(6416):160-164. doi:10.1038/362160a0.

13. Haardt M, Benharouga M, Lechardeur D, Kartner N, Lukacs GL. C-terminal truncations destabilize the cystic fibrosis transmembrane conductance regulator without impairing its biogenesis. A novel class of mutation. $\mathrm{J}$ Biol Chem. 1999;274(31):21873-21877. doi:10.1074/jbc.274.31.21873.

14.Saint-Criq V, Gray MA. Role of CFTR in epithelial physiology. Cell Mol Life Sci. 2017;74(1):93-115. doi:10.1007/s00018-016-2391-y.

15.Zielenski J. Genotype and phenotype in cystic fibrosis. Respiration. 2000;67(2):117-133. doi:10.1159/000029497.

16.Gonçalves AC, Marson FAdL, Mendonça RMdH, et al. Saliva as a potential tool for cystic fibrosis diagnosis. Diagn Pathol. 2013;8:46. doi:10.1186/1746-1596-846.

17.Sokol RZ. Infertility in men with cystic fibrosis. Curr Opin Pulm Med. 2001;7(6):421-426. doi:10.1097/00063198-200111000-00011.

18. Timmreck LS, Gray MR, Handelin B, et al. Analysis of cystic fibrosis transmembrane conductance regulator gene mutations in patients with congenital absence of the uterus and vagina. Am J Med Genet A. 2003;120A(1):72-76. doi:10.1002/ajmg.a.20197.

19.Brooks HL, Driebe WT, Schemmer GG. Xerophthalmia and cystic fibrosis. Arch Ophthalmol. 1990;108(3):354-357. doi:10.1001/archopht.1990.01070050052029. 
20.Lindenmuth KA, Del Monte M, Marino LR. Advanced xerophthalmia as a presenting sign in cystic fibrosis. Ann Ophthalmol. 1989;21(5):189-191.

21.Mrugacz M, Minorowska A, Bakunowicz-Lazarczyk A, Zywalewska N. Zespół suchego oka u dzieci z mukowiscydoza. Med Wieku Rozwoj. 2004;8(4 Pt 1):865-870.

22.Berczeli O, Vizvári E, Katona M, et al. Novel Insight Into the Role of CFTR in Lacrimal Gland Duct Function in Mice. Invest Ophthalmol Vis Sci. 2018;59(1):54-62. doi:10.1167/iovs.17-22533.

23.Boeck K de, Derichs N, Fajac I, et al. New clinical diagnostic procedures for cystic fibrosis in Europe. [Journal of Cystic Fibrosis, 10, S53-S66]. 2011. doi:10.1016/S1569-1993(11)60009-X.

24.Cystic Fibrosis Foundation. Newborn Screening for CF. http://www.cff.org/Whatis-CF/Testing/Newborn-Screening-for-CF/.

25.CF Foundation. Sweat test. https://www.cff.org/What-is-CF/Testing/Sweat-Test/.

26. Rosenstein BJ, Cutting GR. The diagnosis of cystic fibrosis: A consensus statement. The Journal of Pediatrics. 1998;132(4):589-595. doi:10.1016/s00223476(98)70344-0.

27.Sathe M, Houwen R. Meconium ileus in Cystic Fibrosis. J Cyst Fibros. 2017;16 Suppl 2:S32-S39. doi:10.1016/j.jcf.2017.06.007.

28.Parikh NS, Ahlawat R. StatPearls: Meconium lleus. Treasure Island (FL); 2020.

29.Ziegler MM. Meconium Ileus. In: Pediatric Surgery. Elsevier; 2012:1073-1083.

30.Wilschanski M, Durie PR. Pathology of pancreatic and intestinal disorders in cystic fibrosis. J R Soc Med. 1998;91 Suppl 34:40-49. doi:10.1177/014107689809134s07.

31.Singh VK, Schwarzenberg SJ. Pancreatic insufficiency in Cystic Fibrosis. J Cyst Fibros. 2017;16 Suppl 2:S70-S78. doi:10.1016/j.jcf.2017.06.011. 
32.O'Shea D, O'Connell J. Cystic fibrosis related diabetes. Curr Diab Rep. 2014;14(8):511. doi:10.1007/s11892-014-0511-3.

33.Staufer K, Halilbasic E, Trauner M, Kazemi-Shirazi L. Cystic fibrosis related liver disease--another black box in hepatology. Int J Mol Sci. 2014;15(8):1352913549. doi:10.3390/ijms150813529.

34.Kobelska-Dubiel N, Klincewicz B, Cichy W. Liver disease in cystic fibrosis. Prz Gastroenterol. 2014;9(3):136-141. doi:10.5114/pg.2014.43574.

35.Debray D, Kelly D, Houwen R, Strandvik B, Colombo C. Best practice guidance for the diagnosis and management of cystic fibrosis-associated liver disease. $J$ Cyst Fibros. 2011;10:S29-S36. doi:10.1016/S1569-1993(11)60006-4.

36. Herrmann U, Dockter G, Lammert F. Cystic fibrosis-associated liver disease. Best Pract Res Clin Gastroenterol. 2010;24(5):585-592. doi:10.1016/j.bpg.2010.08.003.

37.Popli K, Stewart J. Infertility and its management in men with cystic fibrosis: review of literature and clinical practices in the UK. Hum Fertil (Camb). 2007;10(4):217-221. doi:10.1080/14647270701510033.

38. Geake J, Tay G, Callaway L, Bell SC. Pregnancy and cystic fibrosis: Approach to contemporary management. Obstet Med. 2014;7(4):147-155. doi:10.1177/1753495X14554022.

39.Castellani C, Duff AJA, Bell SC, et al. ECFS best practice guidelines: the 2018 revision. J Cyst Fibros. 2018;17(2):153-178. doi:10.1016/j.jcf.2018.02.006.

40.Standards for the Clinical Care of Children and Adults with cystic fibrosis in the UK. [Cystic fibrosis - our focus -]. 2011.

41.Antibiotic Treatment for cystic fibrosis. [Cystic fibrosis - our focus -]. 2009.

42. Miller MR, Hankinson J, Brusasco V, et al. Standardisation of spirometry. Eur Respir J. 2005;26(2):319-338. doi:10.1183/09031936.05.00034805. 
43. Kerem E, Conway S, Elborn S, Heijerman H. Standards of care for patients with cystic fibrosis: a European consensus. J Cyst Fibros. 2005;4(1):7-26.

doi:10.1016/j.jcf.2004.12.002.

44.Saiman L, Siegel J. Infection control in cystic fibrosis. Clin Microbiol Rev. 2004;17(1):57-71. doi:10.1128/CMR.17.1.57-71.2004.

45.Schelstraete $\mathrm{P}$, van Daele $\mathrm{S}$, Boeck $\mathrm{K}$ de, et al. Pseudomonas aeruginosa in the home environment of newly infected cystic fibrosis patients. Eur Respir J. 2008;31(4):822-829. doi:10.1183/09031936.00088907.

46.Bärbel Palm. Ernährung vor \& nach Lungentransplantation bei Mukoviszidose. 2014.

47.Ernährung von Säuglingen mit Mukoviszidose. [Ein Ratgeber für Eltern und Betreuer]. 2019.

48.Wolfgang Gruberdes, Alexandra Hebestreit, Helge Hebestreit, Arbeitskreis Sport Mukoviszidose e.V. Leitfaden Sport bei Mukoviszidose. [für Betroffene, Eltern, Ärzte, Sporttherapeuten und Physiotherapeuten]. 2004.

49.Wark P, McDonald VM. Nebulised hypertonic saline for cystic fibrosis. Cochrane Database Syst Rev. 2009;(2):CD001506. doi:10.1002/14651858.CD001506.pub3.

50.Mogayzel PJ, Naureckas ET, Robinson KA, et al. Cystic fibrosis pulmonary guidelines. Chronic medications for maintenance of lung health. Am J Respir Crit Care Med. 2013;187(7):680-689. doi:10.1164/rccm.201207-1160OE.

51.Jones AP, Wallis C. Dornase alfa for cystic fibrosis. Cochrane Database Syst Rev. 2010;(3):CD001127. doi:10.1002/14651858.CD001127.pub2.

52.Elkins MR, Robinson M, Rose BR, et al. A controlled trial of long-term inhaled hypertonic saline in patients with cystic fibrosis. N Engl J Med. 2006;354(3):229240. doi:10.1056/NEJMoa043900. 
53.Aitken ML, Bellon G, Boeck K de, et al. Long-term inhaled dry powder mannitol in cystic fibrosis: an international randomized study. Am J Respir Crit Care Med. 2012;185(6):645-652. doi:10.1164/rccm.201109-1666OC.

54.Bilton D, Robinson $\mathrm{P}$, Cooper $\mathrm{P}$, et al. Inhaled dry powder mannitol in cystic fibrosis: an efficacy and safety study. Eur Respir J. 2011;38(5):1071-1080. doi:10.1183/09031936.00187510.

55.Reeves EP, Molloy K, Pohl K, McElvaney NG. Hypertonic saline in treatment of pulmonary disease in cystic fibrosis. ScientificWorldJournal. 2012;2012:465230. doi:10.1100/2012/465230.

56. Lands LC, Stanojevic S. Oral non-steroidal anti-inflammatory drug therapy for cystic fibrosis. Cochrane Database Syst Rev. 2007;(4):CD001505. doi:10.1002/14651858.CD001505.pub2.

57.Ryan G, Singh M, Dwan K. Inhaled antibiotics for long-term therapy in cystic fibrosis. Cochrane Database Syst Rev. 2011;(3):CD001021. doi:10.1002/14651858.CD001021.pub2.

58. Einhorn K, Ballmann M. Pseudomonas aeruginosa eradication therapy on Cystic Fibrosis- Guideline and clinical routine. In: Cystic fibrosis. European Respiratory Society; 09152018:PA1330.

59.Southern KW, Barker PM, Solis-Moya A, Patel L. Macrolide antibiotics for cystic fibrosis. Cochrane Database Syst Rev. 2012;11:CD002203. doi:10.1002/14651858.CD002203.pub4.

60.Kapnadak SG, DiMango E, Hadjiliadis D, et al. Cystic Fibrosis Foundation consensus guidelines for the care of individuals with advanced cystic fibrosis lung disease. J Cyst Fibros. 2020. doi:10.1016/j.jcf.2020.02.015.

61.Bhatt JM. Treatment of pulmonary exacerbations in cystic fibrosis. Eur Respir Rev. 2013;22(129):205-216. doi:10.1183/09059180.00006512. 
62. Anthony H, Collins CE, Davidson G, et al. Pancreatic enzyme replacement therapy in cystic fibrosis: Australian guidelines. Pediatric Gastroenterological Society and the Dietitians Association of Australia. J Paediatr Child Health. 1999;35(2):125-129. doi:10.1046/j.1440-1754.1999.00363.x.

63.Turck D, Braegger CP, Colombo C, et al. ESPEN-ESPGHAN-ECFS guidelines on nutrition care for infants, children, and adults with cystic fibrosis. Clin Nutr. 2016;35(3):557-577. doi:10.1016/j.clnu.2016.03.004.

64.Ren CL, Morgan RL, Oermann C, et al. Cystic Fibrosis Foundation Pulmonary Guidelines. Use of Cystic Fibrosis Transmembrane Conductance Regulator Modulator Therapy in Patients with Cystic Fibrosis. Ann Am Thorac Soc. 2018;15(3):271-280. doi:10.1513/AnnalsATS.201707-539OT.

65.Cystic Fibrosis Foundation. CFTR Modulator Therapies. https://www.cff.org/Life-With-CF/Treatments-and-Therapies/Medications/CFTRModulator-Therapies/. Updated July 28, 2020.000Z. Accessed July 28, 2020.

66.Powell K, Zeitlin PL. Therapeutic approaches to repair defects in deltaF508 CFTR folding and cellular targeting. Adv Drug Deliv Rev. 2002;54(11):13951408. doi:10.1016/s0169-409x(02)00148-5.

67. Kelley TJ, Thomas K, Milgram LJ, Drumm ML. In vivo activation of the cystic fibrosis transmembrane conductance regulator mutant deltaF508 in murine nasal epithelium. Proc Natl Acad Sci U S A. 1997;94(6):2604-2608. doi:10.1073/pnas.94.6.2604.

68.Ramsey BW, Davies J, McElvaney NG, et al. A CFTR potentiator in patients with cystic fibrosis and the G551D mutation. N Engl J Med. 2011;365(18):16631672. doi:10.1056/NEJMoa1105185.

69. Boeck K de, Munck A, Walker S, et al. Efficacy and safety of ivacaftor in patients with cystic fibrosis and a non-G551D gating mutation. J Cyst Fibros. 2014;13(6):674-680. doi:10.1016/j.jcf.2014.09.005. 
70.Mall MA, Galietta LJV. Targeting ion channels in cystic fibrosis. J Cyst Fibros. 2015;14(5):561-570. doi:10.1016/j.jcf.2015.06.002.

71. Nilius B, Droogmans G. Amazing chloride channels: an overview. Acta Physiol Scand. 2003;177(2):119-147. doi:10.1046/j.1365-201X.2003.01060.x.

72.Kerem E, Viviani L, Zolin A, et al. Factors associated with FEV1 decline in cystic fibrosis: analysis of the ECFS patient registry. Eur Respir J. 2014;43(1):125133. doi:10.1183/09031936.00166412.

73.Kapnadak SG, Ramos KJ, Lopriore AM, Goss CH, Aitken ML. A Survey Identifying Nutritional Needs in a Contemporary Adult Cystic Fibrosis Cohort. BMC Nutr. 2019;5. doi:10.1186/s40795-018-0266-3.

74.Bradley JM, Moran FM, Elborn JS. Evidence for physical therapies (airway clearance and physical training) in cystic fibrosis: an overview of five Cochrane systematic reviews. Respir Med. 2006;100(2):191-201. doi:10.1016/j.rmed.2005.11.028.

75. O'Neill PA, Dodds M, Phillips B, Poole J, Webb AK. Regular exercise and reduction of breathlessness in patients with cystic fibrosis. British Journal of Diseases of the Chest. 1987;81:62-69. doi:10.1016/0007-0971(87)90109-4.

76. Orenstein DM, Franklin BA, Doershuk CF, et al. Exercise conditioning and cardiopulmonary fitness in cystic fibrosis. The effects of a three-month supervised running program. Chest. 1981;80(4):392-398. doi:10.1378/chest.80.4.392.

77.Bilton D, Dodd ME, Abbot JV, Webb AK. The benefits of exercise combined with physiotherapy in the treatment of adults with cystic fibrosis. Respir Med. 1992;86(6):507-511. doi:10.1016/s0954-6111(96)80012-6.

78. Moorcroft AJ, Dodd ME, Webb AK. Exercise testing and prognosis in adult cystic fibrosis. Thorax. 1997;52(3):291-293. doi:10.1136/thx.52.3.291. 
79.Nixon PA, Orenstein DM, Kelsey SF, Doershuk CF. The prognostic value of exercise testing in patients with cystic fibrosis. $N$ Engl $\mathrm{J}$ Med. 1992;327(25):1785-1788. doi:10.1056/NEJM199212173272504.

80.Webb AK, Dodd ME. Exercise and sport in cystic fibrosis: benefits and risks. $\mathrm{Br}$ J Sports Med. 1999;33(2):77-78.

81.Liou TG, Adler FR, Cahill BC, et al. Survival effect of lung transplantation among patients with cystic fibrosis. JAMA. 2001;286(21):2683-2689. doi:10.1001/jama.286.21.2683.

82. Todd JL, Christie JD, Palmer SM. Update in lung transplantation 2013. Am J Respir Crit Care Med. 2014;190(1):19-24. doi:10.1164/rccm.201402-0384UP.

83.Estenne M, Kotloff RM. Update in transplantation 2005. Am J Respir Crit Care Med. 2006;173(6):593-598. doi:10.1164/rccm.2601012.

84.Schmitz TG, Goldbeck L. The effect of inpatient rehabilitation programmes on quality of life in patients with cystic fibrosis: a multi-center study. Health Qual Life Outcomes. 2006;4:8. doi:10.1186/1477-7525-4-8.

85.Griese M, Busch P, Caroli D, et al. Rehabilitation Programs for Cystic Fibrosis View from a CF Center. Open Respir Med J. 2010;4:1-8. doi:10.2174/1874306401004010001.

86. Burtin $\mathrm{C}$, Hebestreit $\mathrm{H}$. Rehabilitation in patients with chronic respiratory disease other than chronic obstructive pulmonary disease: exercise and physical activity interventions in cystic fibrosis and non-cystic fibrosis bronchiectasis. Respiration. 2015;89(3):181-189. doi:10.1159/000375170.

87. West CA, Besier T, Borth-Bruhns T, Goldbeck L. Effectiveness of a familyoriented rehabilitation program on the quality of life of parents of chronically ill children. Klin Padiatr. 2009;221(4):241-246. doi:10.1055/s-0029-1216364. 
88. Krauth KA. Family-Oriented Rehabilitation (FOR) and Rehabilitation of Adolescents and Young Adults (AYA) in Pediatric Oncology. Oncol Res Treat. 2017;40(12):752-758. doi:10.1159/000484609.

89.Stephenson AL, Mannik LA, Walsh S, et al. Longitudinal trends in nutritional status and the relation between lung function and BMI in cystic fibrosis: a population-based cohort study. Am J Clin Nutr. 2013;97(4):872-877. doi:10.3945/ajcn.112.051409.

90.Szczesniak R, Heltshe SL, Stanojevic S, Mayer-Hamblett N. Use of FEV1 in cystic fibrosis epidemiologic studies and clinical trials: A statistical perspective for the clinical researcher. J Cyst Fibros. 2017;16(3):318-326. doi:10.1016/j.jcf.2017.01.002.

91.Gee L, Abbott J, Conway SP, Etherington C, Webb AK. Quality of life in cystic fibrosis: the impact of gender, general health perceptions and disease severity. J Cyst Fibros. 2003;2(4):206-213. doi:10.1016/S1569-1993(03)00093-6.

92. Hirche TO, Loitsch S, Smaczny C, Wagner TOF. Neue Konzepte zur Pathophysiologie und Therapie der Mukoviszidose. Pneumologie. 2005;59(11):811-818. doi:10.1055/s-2005-915557.

93. Hayllar KM, Williams SG, Wise AE, et al. A prognostic model for the prediction of survival in cystic fibrosis. Thorax. 1997;52(4):313-317. doi:10.1136/thx.52.4.313.

94.Liou TG, Adler FR, Fitzsimmons SC, Cahill BC, Hibbs JR, Marshall BC. Predictive 5-year survivorship model of cystic fibrosis. Am J Epidemiol. 2001;153(4):345-352. doi:10.1093/aje/153.4.345.

95.Kerem E, Reisman J, Corey M, Canny GJ, Levison H. Prediction of mortality in patients with cystic fibrosis. N Engl J Med. 1992;326(18):1187-1191. doi:10.1056/NEJM199204303261804. 
96.Keating C, Poor AD, Liu X, et al. Reduced survival in adult cystic fibrosis despite attenuated lung function decline. J Cyst Fibros. 2017;16(1):78-84. doi:10.1016/j.jcf.2016.07.012.

97.Nährlich L., Burkhart M., Wiese B. German CF-Registry Annual Report 2015. 2016. Accessed June 11, 2019.

98.Ackermann H. BiAS: Biometrische Analyse von Stichproben. Version 8.2, 19892006. Frankfurt am M; 2006.

99.Yi S-W, Ohrr H, Shin S-A, Yi J-J. Sex-age-specific association of body mass index with all-cause mortality among 12.8 million Korean adults: a prospective cohort study. Int J Epidemiol. 2015;44(5):1696-1705. doi:10.1093/ije/dyv138.

100. Hayes A, Gearon E, Backholer K, Bauman A, Peeters A. Age-specific changes in BMI and BMI distribution among Australian adults using crosssectional surveys from 1980 to 2008. Int J Obes (Lond). 2015;39(8):1209-1216. doi:10.1038/ijo.2015.50.

101. Lungenfunktionstest - Normwerte | Leichter-atmen.de. https://www.leichteratmen.de/lungenfunktionstest-werte. Accessed June 11, 2019.

102. Ho DE, Imai K, King G, Stuart EA. Matchlt : Nonparametric Preprocessing for Parametric Causal Inference. J Stat Soft. 2011;42(8). doi:10.18637/jss.v042.i08.

103. Quanjer PH, Stanojevic S, Cole TJ, et al. Multi-ethnic reference values for spirometry for the 3-95-yr age range: the global lung function 2012 equations. Eur Respir J. 2012;40(6):1324-1343. doi:10.1183/09031936.00080312.

104. Statistisches Bundesamt der Bundesrepublik Deutschland. Körpermaße nach Altersgruppen und Geschlecht. https://www.destatis.de/DE/Themen/GesellschaftUmwelt/Gesundheit/Gesundheitszustand-Relevantes-Verhalten/Tabellen/listekoerpe- 
rmasse.html;jsessionid=C7F5C7ACF13C6978E29DDF5BECA2E9C1.internet73 2. Accessed June 11, 2019.

105. Shalnova S, Vilkov V, Balanova Y, et al. P4451Comparison of the body mass index in the populations of the Russian Federation and the United States of America during thirty years period. European Heart Journal. 2018;39(suppl_1).doi:10.1093/eurheartj/ehy563.P4451.

106. World Health Organization, Regional Office for Europe. Russian Federation - WHO Country Profile. Accessed June 11, 2019.

107. Rtveladze K, Marsh T, Webber L, et al. Obesity trends in Russia. The impact on health and healthcare costs. Health. 2012;04(12):1471-1484. doi:10.4236/health.2012.412A212.

108. Sachs L. Angewandte Statistik. Berlin, Heidelberg: Springer Berlin Heidelberg; 2004.

109. Toutenburg H. Hollander, M., D. A. Wolfe: Nonparametric statistical methods. John Wiley \& Sons, New York-Sydney-Tokyo-Mexico City 1973. 503 S., \$9.50. Biom J. 1975;17(8):526. doi:10.1002/bimj.19750170808.

110. Cohen J. Statistical Power Analysis for the Behavioral Sciences. 2nd ed. Hoboken: Taylor and Francis; 2013. http://gbv.eblib.com/patron/FullRecord.aspx?p=1192162.

111. Zimmmermann H. Exact Calculation of Permutational Distributions for Two Independent Samples. Biom J. 1985;27(4):431-434. doi:10.1002/bimj.4710270414.

112. Smaczny C, Eickmeier O. Abläufe im CHCZ-Zentrum Frankfurt am Main "E" + "K". 2015.

113. RKI - Robert-Koch-Institut. Erfassung der SARS-CoV-2-Testzahlen. https://www.rki.de/DE/Content/InfAZ/N/Neuartiges_Coronavirus/Testzahl.html?n $n=13490888$. 
114. Stopkoronavirus.rf - Die offizielle Online-Ressource zur Information der Öffentlichkeit über Coronavirus-Probleme (COVID-19). Operational data - official information about coronavirus in Russia. https://стопкоронавирус.pф/.

115. Pettit RS, Fellner C. CFTR Modulators for the Treatment of Cystic Fibrosis. P T. 2014;39(7):500-511.

116. Lopes-Pacheco M. CFTR Modulators: The Changing Face of Cystic Fibrosis in the Era of Precision Medicine. Front Pharmacol. 2019;10:1662. doi:10.3389/fphar.2019.01662.

117. Tümmler B. Therapie der Mukoviszidose mit CFTR-Modulatoren. Pneumologie. 2016;70(5):301-313. doi:10.1055/s-0042-100607.

118. Smaczny C, Eickmeier O, Wagner TOF. Transition in der Pneumologie. Pneumologe. 2013;10(1):13-19. doi:10.1007/s10405-012-0595-x.

119. Häfner L, Peters G, Kahl BC. Assessment of microbiological diagnostic procedures for respiratory specimens from cystic fibrosis patients in German laboratories by use of a questionnaire. J Clin Microbiol. 2014;52(3):977-979. doi:10.1128/JCM.02866-13.

120. Popovich L, Potapchik E, Shishkin S, Richardson E, Vacroux A, Mathivet B. Russian Federation. Health system review. Health Syst Transit. 2011;13(7):1190, xiii-xiv.

121. Vertakova J, Vlasova O. Problems and Trends of Russian Health Care Development. Procedia Economics and Finance. 2014;16:34-39. doi:10.1016/S2212-5671(14)00771-0.

122. Stern M, Wiedemann B, Wenzlaff P. From registry to quality management: the German Cystic Fibrosis Quality Assessment project 1995 2006. Eur Respir J. 2008;31(1):29-35. doi:10.1183/09031936.00056507.

123. Nährlich, Burkhart, Wiese. Deutsches Mukoviszidose-Register Berichtsband 2015. 2016. Accessed June 11, 2019. 
124. Corey M, McLaughlin FJ, Williams M, Levison $\mathrm{H}$. A comparison of survival, growth, and pulmonary function in patients with cystic fibrosis in Boston and Toronto. J Clin Epidemiol. 1988;41(6):583-591.

125. Sharma R, Florea VG, Bolger AP, et al. Wasting as an independent predictor of mortality in patients with cystic fibrosis. Thorax. $2001 ; 56(10): 746-750$. doi:10.1136/thorax.56.10.746.

126. Hurley MN, Prayle AP, Flume P. Intravenous antibiotics for pulmonary exacerbations in people with cystic fibrosis. Cochrane Database Syst Rev. 2015;(7):CD009730. doi:10.1002/14651858.CD009730.pub2. 


\section{Lebenslauf}

Akademischer Werdegang

10/2013 - 11/2019: Medizinstudium, Goethe-Universität Frankfurt am Main
»11/2019:
3. Staatsexamen

»07/2019 - 10/2019:

3. Tertial des Praktischen Jahres

Augenheilkunde

Klinikum der Johann Wolfgang Goethe-Universität Frankfurt am Main

$\begin{array}{ll}\text { »03/2019-06/2019: } & \text { 2. Tertial des Praktischen Jahres }\end{array}$ Innere Medizin Hospital zum Heiligen Geist, Frankfurt am Main

»11/2018 - 03/2019: 1. Tertial des Praktischen Jahres Chirurgie Hospital zum Heiligen Geist, Frankfurt am Main

$\begin{array}{ll}\text { 10/2018: } & \text { 2. Staatsexamen }\end{array}$

» 07/2017 + 10/2017: Famulatur, Hausarztpraxis Dr. Wittmann und Dr. Trepels, NeuIsenburg

» 03/2017 - 04/2017: Famulatur, Kardiologie, Sana- 
Klinikum, Offenbach am Main

»01/2017 - 02/2017: Famulatur, Orthopädische

Universitätsklinik Friedrichsheim, Frankfurt am Main

» 09/2016 - 10/2016: Famulatur, Institut für medizinische Mikrobiologie, Virologie und Hygiene, Klinikum der Johann Wolfgang Goethe-Universität, Frankfurt am Main

»09/2015:

1. Staatsexamen

»03/2015 und Krankenpflegepraktikum, Geriatrie 08/2014 - 09/2014 und Palliativmedizin, Hôpital local de Ribérac (Frankreich)

Beruflicher Werdegang

»11/2016-04/2018: Wissenschaftliche Hilfskraft im Institut für medizinische Mikrobiologie, Virologie und Hygiene am Klinikum der Johann Wolfgang Goethe-Universität Frankfurt am Main 
Schulischer Werdegang

09/2000-06/2013 : Schulische Ausbildung, Lycée français Victor Hugo de

Francfort, Frankfurt am Main

»06/2013:

Baccalauréat 2013; Gesamtnote:

1,0 (Mention très bien; Gesamtnote: $17,21 / 20)$

»06/2013:

Abi-Bac 2013; Gesamtnote 1,4 


\section{Danksagung}

Ich möchte mich an dieser Stelle herzlich bei allen bedanken, die mit ihrer Unterstützung zur Fertigstellung dieser Arbeit verholfen haben.

Mein besonderer Dank gilt Herrn Prof. Dr. med. Thomas O.F. Wagner, der mich als Doktorand in sein Team aufgenommen hat und mir dieses spannende Thema anvertraut hat und stets mit Hilfestellungen durch diese Arbeit hindurch begleitet hat. Sein Vertrauen, seine wertvollen Erfahrungen, seine Ideen und seine Geduld möchte ich insbesondere hervorheben.

Ich möchte mich ebenfalls bei Frau Dr. med. Christina Smaczny für die Unterstützung im Rahmen des Umgangs mit der Kliniksoftware und der Datenerhebung bedanken. Mit Zuverlässigkeit, außerordentlichem Engagement, konstruktiver Kritik, hervorragender Erreichbarkeit konnte sie mir oft zur Seite stehen.

Einen Dank gilt es auch Frau Prof. Dr. med. Gulja Babadjanova und ihren Mitarbeitern auszusprechen, die mir bei der Datenerhebung, dem interessanten bilateralen Austausch und einer ideenreichen Unterstützung ebenfalls oft ihre Hilfe anboten.

Für weitere Unterstützung im Rahmen der Doktorarbeit möchte ich Herrn Dr. med. Olaf Eickmeier danken.

Schließlich geht ein ganz besonderer Dank an Dr. Alexander Witek, der mir mit seinen hervorragenden Englischkenntnissen weiterhelfen konnte. Nicht vergessen möchte ich meine Eltern - Dr. François Varescon und Dr. Marie-Laure Varescon -, die mich unermüdlich zu Hause unterstützt haben und mir ideale Rahmenbedingungen zur Zusammenstellung dieser Schrift geschaffen haben.

Danke für die Rückenstärkung und die Motivation auch an meinen sehr guten Freund - Florian Schneider -, der mir mit Rat immer zur Seite stand, wenn ich es 
nötig hatte und mir auch spät abends bei Diskussionen am Telefon Veränderungsvorschläge bot. 


\section{Schriftliche Erklärung}

Ich erkläre ehrenwörtlich, dass ich die dem Fachbereich Medizin der Johann Wolfgang Goethe-Universität Frankfurt am Main zur Promotionsprüfung eingereichte Dissertation mit dem Titel

Comparison of surrogate parameters of prognosis (BMI, FEV1 and need of intravenous antibiotic therapy) between CF-patients with and without $P$. aeruginosa in Frankfurt and Moscow from 1990 to 2015

in dem Christiane Herzog CF-Zentrum, Pneumologie, Medizinische Klinik I unter Betreuung und Anleitung von Prof. Dr. Thomas O.F. Wagner mit Unterstützung durch Dr. Christina Smaczny ohne sonstige Hilfe selbst durchgeführt und bei der Abfassung der Arbeit keine anderen als die in der Dissertation angeführten Hilfsmittel benutzt habe. Darüber hinaus versichere ich, nicht die Hilfe einer kommerziellen Promotionsvermittlung in Anspruch genommen zu haben.

Ich habe bisher an keiner in- oder ausländischen Universität ein Gesuch um Zulassung zur Promotion eingereicht*. Die vorliegende Arbeit wurde bisher nicht als Dissertation eingereicht. 


\section{Ethikvotum}

Das Ethikvotum zur retrospektiven Studie wurde von der Ethik-Kommission des Fachbereichs Medizin des Universitätsklinikums der Goethe-Universität Frankfurt am Main am 23.05.2017 genehmigt. Es bestanden keine berufsrechtlichen und berufsethischen Bedenken zur Durchführung der Studie und der Dissertation.
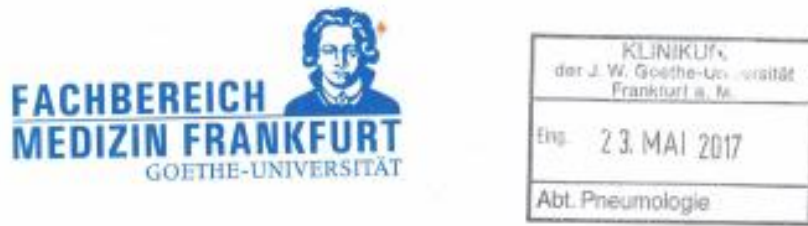

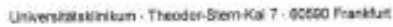

\section{IM HAUSE}

Medizinische Klinik I

Pneumologie / Allergologie

Herr Prof. Dr. Thomas Wagner

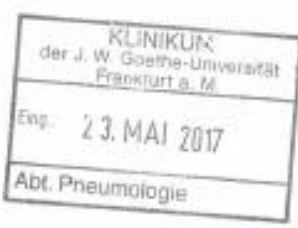

Geschäfts-Nr:: $183 / 17$ (Bitte stets angeben!)

Titel: Vergleich der Surrogatmarker (BMI, FEV1 und Notwendigkeit einer intravenosen Antibiotikatherapie) von Mukoviszidosepatienten mit und ohne Pseudomonas aeruginosa-Nachweis in Frankfurt und einem anderen Standort zwischen 1990 und 2015

voTuM

Sehr geehrter Herr Professor Wagner,

vielen Dank für die Zusendung der Studienunterlagen vom 25.04.2017.

Es bestehen keine berufsrechtlichen und berufsethischen Bedenken. Die Ethik-Kommission erteilt eine zustimmende Bewertung.

Hinweise:

1. Wir gehen davon aus, dass der Erfassungszeitraum auf 1990-2015 begrenzt ist.

2. Die Ethik-Kommission weist darauf hin, dass bei der Einsichtnahme der Unterlagen $\S 12$ Hessisches Krankenhausgesetz in Verbindung mit § 33 Hessisches Datenschutzgesetz eingehalten werden muss.

Eine Information Ober den Abschluss der Studie wird erbeten.

Mit freundlichen Grußen

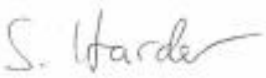

Prof. Dr. med. Sebastian Harder

Vorsitzender der Ethik-Kommission

Vorgelegte Unterlagen:

- Protokoli, V.1.0 vom 25.04.2017
Ethik-Kommission

Vorsitz:

Prot. Dr. Sebastian Harder

Geschaftsfuhrung:

Or. Annette Malseh

Bearbeitung des Vorgangs:

Siemier

Montag, 22 Mai 2017

Geschaftsstelle

Mitarbeitarlinnen:

Ounctwahl

Wuriam Ruggen Tel: 7239
Sogine Slemise

Face o34se

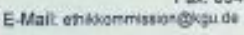

ntpiverik kommisson kitik unt-

tratklus ds

Lletoradresse:

Fochbereichs Medizin

Universtatsidnikum der

Geethe-Universtat

Theodor-Stern Kai ?

Haus 1, 2 Ob. Za 229/22

60596 Frankfurt am Mais

Offnungszeiten t. Anlieferungen:

Mortag bis Frehtag
$9: 00$ bis 1530 une 


\section{FACHBEREICH \\ GOETHE-UNIVERSITÄT}

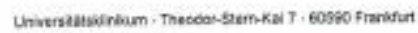

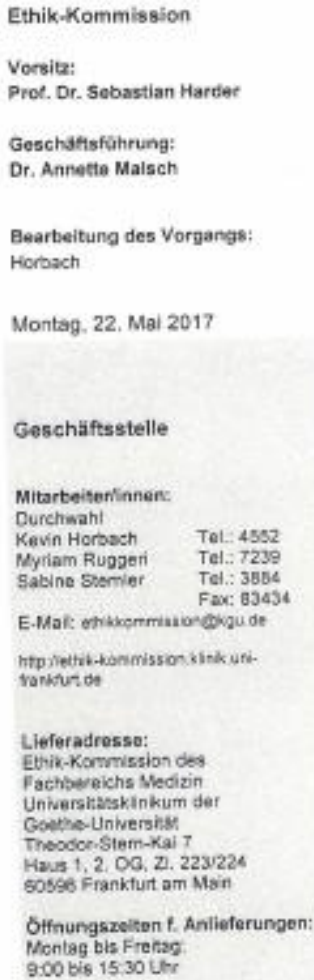

Die Buchung ist zeitnah, auf jeden Fall bis 8 Tage nach Weisungsdatum, auszufuhren. Bei Verzógerungen sind die in diesem Schreiben genannten Beteiligten umgehend zu informieren.

Mit freundlichen Grußen

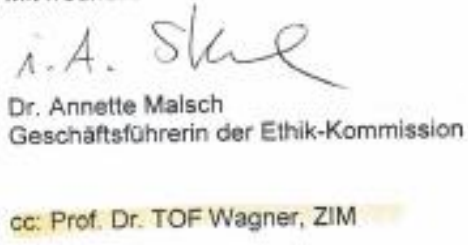

\section{A}

